Camila Righetto Cassano

\title{
Cobertura florestal e intensificação do manejo: desafios para manutenção de biodiversidade em mosaicos agroflorestais
}

Forest cover and management intensification: challenges for biodiversity maintenance in agroforestry mosaics

São Paulo 


\section{Cobertura florestal e intensificação do manejo: desafios para manutenção de biodiversidade em mosaicos agroflorestais}

Forest cover and management intensification: challenges for biodiversity maintenance in agroforestry mosaics

Tese apresentada ao Instituto de Biociências da Universidade de São Paulo, para obtenção de Título de Doutor em Ciências, na área de Ecologia.

Orientadora: Renata Pardini

São Paulo 
Cassano, Camila Righetto

Cobertura florestal e intensificação do manejo: desafios para manutenção de biodiversidade em mosaicos agroflorestais

Número de páginas: 131

Tese (Doutorado) - Instituto de Biociências da Universidade de São Paulo. Departamento de Ecologia.

1. Sistema agroflorestal 2. Conservação 3. Mamífero 4. Matriz 5. Paisagem I. Universidade de São Paulo. Instituto de Biociências. Departamento de Ecologia.

Comissão Julgadora:

$\operatorname{Prof}(a) . \operatorname{Dr}(a)$

$\operatorname{Prof}(a) . \operatorname{Dr}(a)$.
Prof(a). Dr(a).

$\operatorname{Prof}(a) . \operatorname{Dr}(a)$.

Prof(a). Dr(a). Renata Pardini

Orientadora 
"Noite de escuro não serve

Pra caçar de madrugada

Caçador dá muito tiro, o iaiá

De manhã não acha nada

Veado corre é pulando

Cotia corre na trilha

Se eu fosse governador

Ah, Meu Deus, manobrasse a Bahia

Isso que tu tá fazendo

Comigo tu não fazia, camará

Iê, é hora é hora..."

(ladainha de capoeira, Mestre Paulo dos Anjos) 
Agradeço imensamente à Dr. Renata Pardini, orientadora e amiga, pela inspiração profissional e dedicação desde as primeiras idéias que deram origem a este trabalho até as últimas correções que tornaram esta versão da tese possível. Re, foi um grande prazer trabalhar com você e espero que nossa parceria não acabe aqui.

Obrigada Dr. Jos Barlow por me receber na Universidade de Lancaster para a realização de um estágio, e assim me dar a oportunidade de conhecer novos lugares e amigos. Sou muito grata por sua contribuição na reta final deste trabalho e por me ensinar um pouco mais sobre como concatenar ideias e argumentos e assim produzir um bom texto científico.

À Fundação de Amparo à Pesquisa do Estado de São Paulo pela bolsa de estudo concedida (07/54888-1) e às Instituições que possibilitaram as atividades de campo através de financiamentos concedidos ao Instituto de Estudos Socioambientais do Sul da Bahia (IESB): Ministério do Meio Ambiente (Projetos Demonstrativos de Desenvolvimento Sustentável - PDA), União Européia e Seeds of Change.

A todos os companheiros de trabalho do IESB onde o presente trabalho teve sua origem e tantos outros estudos relacionados à conservação da floresta Atlântica do sul da Bahia foram, são e serão realizados. Agradeço especialmente a Gabriel Rodrigues dos Santos, Ana Claudia Fandi e Ana Roberta Gomes pelos vários anos em que trabalhamos juntos, por todos os sonhos e realizações compartilhados. Aos pesquisadores que passaram ou ainda atuam no IESB, com quem pude compartilhar experiências e amizade: Raquel, Gustavo, Priscila, Leo Neves e Oliveira, Lilian, Carlos, Cassiano, André, Becky, Michaele, Letícia, Larissa, Samantha entre outros... A todos os profissionais que atuam e/ou atuaram em diversas atividades de extensão do IESB, com quem conheci a região de Una e iniciativas para conciliar a conservação da natureza e o bem-estar da população humana.

Obrigada a André de Luca e Patrícia Ruggero, pelas contribuições ao projeto que originou este estudo, através da parceria entre IESB e SAVE-Brasil. Göets Schroth, Deborah Faria, Lucio Bede, Jacques Delabie e Leonardo Oliveira obrigada por compartilharem o interesse no estudo da biodiversidade nas agroflorestas de cacau do sul da Bahia e pelas discussões e iniciativas para que pesquisas saiam do papel e encontrem um campo fértil.

Paulo Inácio, agradeço especialmente pelos ensinamentos sobre análises de dados, mas também pela dedicação ao curso de Pós-Graduação em Ecologia do IB junto com dois 
outros professores que marcaram minha passagem por aqui: Alexandre Adalardo e Glauco Machado.

Agradeço imensamente a Rubens Vieira Lopes, por todas as risadas e aventuras "off road" e, acima de tudo, por sua grande motivação e competência como auxiliar de campo. Agradeço também aos estagiários Alexandre Basílio Rodrigues e Suzane Dias de Sousa pela ajuda no trabalho de campo e na compilação de dados.

Aos proprietários das 30 fazendas onde o estudo foi realizado, por permitirem nossa entrada e a realização da coleta de dados. Aos moradores e trabalhadores dessas mesmas fazendas pelas orientações no campo, pelos cafezinhos e por muitas histórias. Aos proprietários das fazendas Cosme e Damião, Piruna e Ribeirão das Pedras pela hospedagem durante o trabalho de campo. Sr. Zezito e Dona Conceição e o trio Elaine, Elsinho e Zezinho, pela diversão nos fins de tarde na Fazenda Palmeiras. Sr. Bonfim e Dona Reni pelo exemplo lindo de harmonia com seu pedaço de terra e pelo acolhimento. Lelê, professora de Vila Brasil, sempre alegre e disposta a ajudar. Seu Zito, agricultor do assentamento Santo Antônio, pela generosidade e exemplo de persistência. A todos esses tantos outros moradores das vilas e fazendas de Una e Arataca que no seu dia-a-dia constroem a paisagem onde este estudo foi realizado, pela simplicidade invejável com que levam a vida e enfrentam as dificuldades de viver em uma região abandonada pelo poder público.

A toda minha família pelo carinho e exemplo de união e amor. Meu maior agradecimento a Neli, Salva e Ale, por me apoiarem nas minhas decisões mais malucas e estarem sempre presentes na minha vida. Jú e Thaís por me confortarem na minha chegada gradual a São Paulo. Rafa, meu companheiro, que me conheceu no comecinho desse doutorado e apesar da minha ausência, consequência de viagens e horas no computador, continua ao meu lado e me faz feliz. Roueda, Nanã, Valéria, João (Grande e Pequeno), Clarinha, Joice, França, Carla, Maíra e, de novo, "Anas", Leo, Gabi e Pri, amigos que são minha grande família em Ilhéus.

Aos companheiros do Laboratório de Diversidade e Conservação de Mamíferos: Thomas, Camilinha, Cá Pagotto, Thaís, Juliana, Enrico, Bruno, Paulinha, Karina e Patrícia, pelas conversas, incentivos e ensinamentos; e Gustavo, por tantos artigos e scripts compartilhados com muito bom humor. Aos amigos do departamento de Ecologia: Rodolfo 
(Chubaca), grande figura, Jomar, queridíssimo, que nunca me deixou ir morar debaixo da ponte!!! Cris Banks, Camila Castanho e Melina pelas conversas, cafés, risadas, etc...

Ricardo, Clare, Emily, Ali, George, Al, Patty, Rachel, Rachael, Amanda, Marcelo, Nicolas, Luís e Sandra pela curta, porém deliciosa temporada vivida em Lancaster, Inglaterra.

Agradeço à capoeira por me trazer o equilíbrio fundamental pra minha vida, saúde e a alegria de tantos amigos. Aos companheiros do grupo Mucumbo, minha casa: Roueda, Nestor, Fabio, André, Teco, Namara e Clarinha, e do grupo Nzinga, onde fui acolhida nos últimos dois anos em São Paulo: Manô, Bianca, Laura, Daniel, Ana Paula, Mauro, Ângelo, Mais Novo, Leo, Serginho, Dedê, Dênis, Di Boa, Barba, Raquel, Mandala, Roberto, Tião, Lilian, Maré... Ao meu querido Mestre Virgílio pela inspiração e ensinamentos por caminhos tão diferentes dos da ciência.

Às florestas do sul da Bahia que, com sua beleza e espíritos, me inspiraram a trabalhar pela conservação.

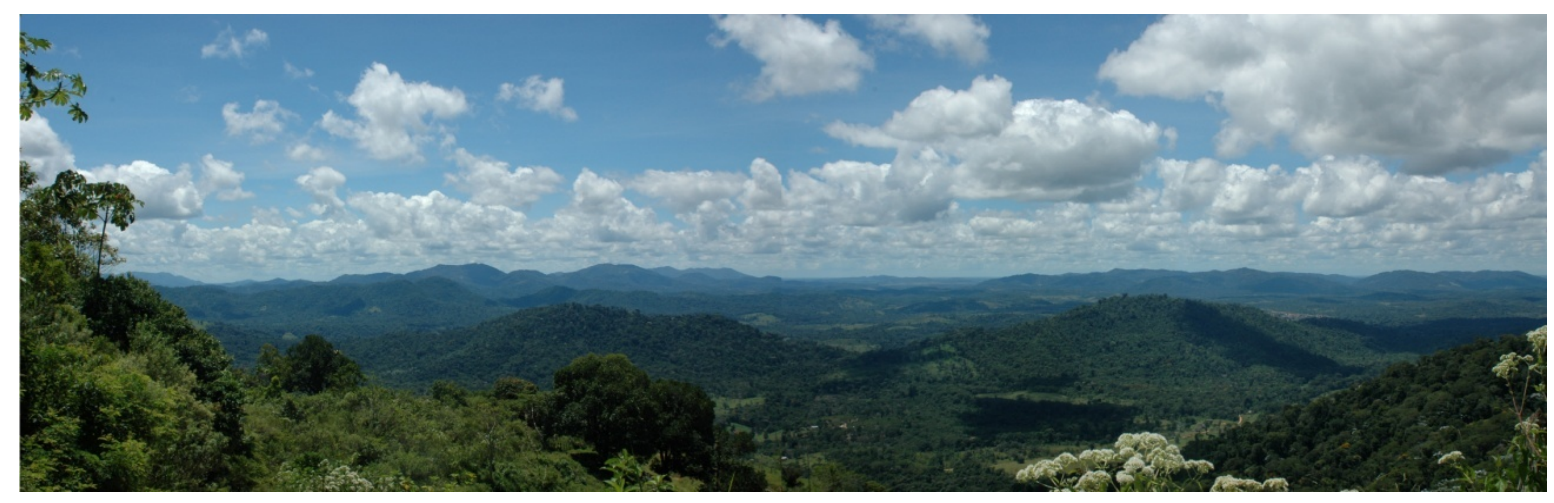




\section{ÍNDICE}

\begin{tabular}{l|c|}
\hline Resumo & 1
\end{tabular}

\begin{tabular}{l|l|l|l}
\hline Abstract & 3
\end{tabular}

\begin{tabular}{l|l|l} 
Introdução Geral & 5
\end{tabular}

Capítulo 1: Landscape and farm scale management to enhance biodiversity

conservation in the cocoa producing region of southern Bahia, Brazil

Abstract

1.1. Introduction

1.2. Methods

1.3. Results

1.4. Discussion and recommendations

1.5. Conclusions

Capítulo 2: Large mammals in an agroforestry mosaic in the Brazilian

Atlantic forest

Abstract

2.1. Introduction

2.2. Methods

2.3. Results

2.4. Discussion

2.5. Conclusion

2.6. Supporting Information

Capítulo 3: Forest loss or management intensification? Proximal causes of mammal decline in cacao agroforests

Abstract

3.1. Introduction

3.2. Methods

3.3. Results

3.4. Discussion

3.5. Conclusion

3.6. Supporting Information 
Sistemas agroflorestais abrigam grande biodiversidade quando comparados a outros usos da terra e representam uma ferramenta importante para conciliar produção agrícola e conservação de recursos naturais em paisagens modificadas pelo homem. Esta tese é composta de três capítulos que sintetizam e ampliam o conhecimento a respeito da influência do manejo das agroflorestas e da cobertura florestal remanescente sobre a distribuição dos organismos e apontam ações visando a conservação de biodiversidade em mosaicos agroflorestais. No primeiro capítulo, revisamos a informação científica publicada até 2008 sobre a diversidade da fauna e flora nativas nas agroflorestas de cacau do sul da Bahia. Com base nesta síntese, identificamos recursos chave presentes nessas plantações que se relacionam com a maior riqueza de espécies ou presença de táxons ameaçados e evidenciamos a importância da manutenção de florestas nativas em mosaicos agroflorestais. Finalizamos esta revisão com recomendações para um manejo adaptativo visando a conservação de biodiversidade em propriedades e mosaicos agroflorestais e levantamos questões a serem respondidas por estudos futuros. Nos capítulos 2 e 3, apresentamos dois estudos empíricos realizados a partir da amostragem de mamíferos por armadilhas fotográficas em 30 agroflorestas e remanescentes florestais adjacentes a nove delas. No segundo capítulo, construímos e testamos hipóteses que descrevem quais espécies de mamífero de maior porte com ocorrência na região devem ser positiva e negativamente influenciadas pela conversão de florestas em agroflorestas e como estas respostas diferenciais deveriam se refletir na estrutura, composição e diversidade das assembléias. O valor de conservação das agroflorestas é apoiado pela presença de espécies endêmicas ou ameaçadas de extinção e pela composição similar de espécies entre florestas e agroflorestas. Entretanto, ao identificar que espécies caçadas e mortas por retaliação são raras ou ausentes na nossa amostragem e que agroflorestas são menos usadas por espécies arborícolas e mais usadas por espécies exóticas do que as florestas, nós explicitamos porque o valor de conservação das agroflorestas deve ser visto com cuidado, destacando questões que podem contribuir para a viabilidade das populações de mamíferos de maior porte em paisagens agroflorestais. No terceiro capítulo, contrastamos a importância relativa da intensificação do manejo e da cobertura florestal do entorno sobre o uso das agroflorestas de cacau por mamíferos de maior porte. Nossos resultados indicam que, na paisagem de estudo, fatores diretamente e indiretamente relacionados à intensificação do 
manejo das agroflorestas são mais importantes para a distribuição das espécies de mamíferos do que a quantidade de florestas remanescentes no entorno. A taxa de registro de cães domésticos (fator indireto) teve efeito negativo sobre várias espécies de mamíferos, enquanto a redução da conectividade do dossel das agroflorestas (diretamente associada ao manejo do sombreamento) teve um efeito negativo sobre espécies arborícolas e a redução da altura do estrato herbáceo (diretamente associada à freqüência de roçagem) um efeito positivo para uma espécie generalista. Por outro lado, nesse mosaico agroflorestal com grande quantidade de florestas nativas remanescentes, apenas as espécies generalistas responderam à variação da quantidade de florestas no entorno, sendo mais comuns em agroflorestas circundadas por menor quantidade de floresta. Assim, em mosaicos agroflorestais com elevada cobertura florestal, restringir os efeitos negativos decorrentes da intensificação do uso da terra, como o controle das populações de cães domésticos e das atividades de caça e o planejamento cuidadoso do sombreamento das agroflorestas, deve resultar em maiores benefícios para o uso das agroflorestas por mamíferos de maior porte do que alterações na configuração espacial dos remanescentes florestais. Entretanto, a importância da cobertura florestal em relação à intensificação do manejo deve aumentar em paisagens mais desmatadas. Em conjunto, os três capítulos desta tese mostram que o conhecimento científico atual pode embasar o desenho de práticas e políticas públicas para conciliar produção agrícola e conservação em mosaicos agroflorestais. Tais práticas devem ser continuamente avaliadas, contribuindo e sendo repensadas com o avanço do conhecimento científico. 
Agroforestry systems harbor high levels of biodiversity if contrasted to other land uses and represent an important tool to reconcile agricultural production and conservation in humanmodified landscapes. This thesis is composed of three chapters that synthesize and expand the knowledge on the influence of agroforest management and remaining forest cover on the distribution of organisms, and highlight practices aiming biodiversity conservation in agroflorestry mosaics. In the first chapter we review the scientific information published until 2008 on the diversity of native fauna and flora in cacao agroforests in southern Bahia. Based on this synthesis, we identify key agroforest resources associated with higher species richness or the presence of threatened taxa, and emphasize the importance of forest cover maintenance in agroforestry mosaics. We end this review with recommendations to an adaptive management aiming biodiversity conservation on farms and agroforestry mosaics and consider issues to be developed by future studies. On chapters 2 and 3 we present two empirical studies based on photographic records of large mammals in 30 agroforests and forest remnants adjacent to nine of them. In the second chapter we constructed and tested hypotheses describing which mammals from the regional species pool should be positively and negatively influenced by the conversion of forest to agroforests and how these differential responses should change assemblage structure, composition, and diversity. The high conservation value of agroforests is supported by the presence of species of conservation concern, and a similar species composition between forests and agroforests. However, by identifying that hunted and persecuted species are rare or absent in our samples, and that agroforests are less used by arboreal species and more used by non-native species than forest, we explicit why the conservation value of agroforests should be viewed with caution and underline issues that should be addressed to improve the viability of large mammal populations in agroforestry mosaics. In the third chapter we contrast the relative importance of management intensification and surrounding forest cover for the use of agroforests by large mammals. Our results indicate that, in the studied landscape, factors directly and indirectly related to management intensification are more important to define large mammal distribution than the amount and spatial arrangement of surrounding forest cover. High domestic dog capture rate (an indirect factor) had a negative effect on several species, while low canopy connectivity (directly associated to shade management) was negative correlated to the distribution of arboreal 
species and lower herbaceous vegetation (directly associated to ground vegetation clearance) had a minor positive influence on generalist species. On the other hand, in this agroforestry mosaic highly covered by native forests, only generalist species responded (positively) to the decrease in surrounding forest cover. In agroforestry mosaics from highly forested regions, restricting the negative effects of land-use intensification, such as the control of domestic dog populations and overhunting, and the careful planning of shade management, is likely to bring greater benefit to large mammal use of agroforests than the spatial arrangement of forest remnants. However, the importance of forest cover relative to management intensification is likely to be higher as deforestation increases. The three chapters show that current scientific knowledge can already support policy and management practices to conciliate agricultural production and biodiversity conservation in agroforestry mosaics. Such practices should be continuously evaluated, contributing to and being supported by improvement of scientific knowledge. 


\section{INTRODUÇÃO GERAL}

A conciliação entre o aumento da produção agro-pecuária, que depende do avanço da conversão de vegetação nativa ou da intensificação do manejo dos agroecossistemas, e a conservação de biodiversidade e serviços ambientais representa um dos grandes desafios para a humanidade neste século (Sala et al. 2000, Foley et al. 2005, MEA 2005). A conversão de vegetação nativa e a intensificação do uso do solo têm impactos especialmente relevantes sobre as florestas tropicais, onde se concentra a maior parcela das espécies terrestres (Sala et al. 2000, Laurance 2007). A demarcação de áreas protegidas por lei, sejam elas Unidades de Conservação, Reservas Legais ou Áreas de Preservação Permanente, é uma ferramenta importante para a manutenção da biodiversidade e serviços ambientais que contribuem para o bem estar humano. Entretanto, esses ecossistemas protegidos são influenciados por perturbações das áreas adjacentes e sua manutenção em longo prazo depende de processos ecológicos que acontecem em escalas espaciais mais amplas (Chazdon et al. 2009, Gardner et al. 2009). A necessidade de maximizar os ganhos ambientais em paisagens dominadas por ecossistemas modificados pelo homem tem impulsionado o desenvolvimento de disciplinas como ecologia de paisagens, biologia da conservação e ecologia da restauração (Ehrlich 2007). Sínteses do conhecimento em tais áreas têm possibilitado a construção de princípios gerais para nortear o manejo de paisagens (Lindenmayer \& Hobbs 2007, Lindenmayer et al. 2008, Gardner et al. 2009). No entanto, a compreensão de peculiaridades regionais, tanto no que diz respeito aos ecossistemas naturais quanto ao histórico de ocupação e cenário sócio-político-econômico atual, são fundamentais para que tais princípios sejam implementados com sucesso (Fischer et al. 2008, Gardner et al. 2009, Gardner et al. 2010).

A redução da quantidade de vegetação nativa em uma paisagem influencia por si só a biota, pois representa uma diminuição da quantidade de habitat e recursos disponíveis para as espécies restritas a esse(s) ecossistema(s). Além disso, quanto menor a quantidade de vegetação remanescente, maior a tendência de formação de fragmentos de habitat, que se tornam menores e mais distantes entre si à medida que novos desmatamentos acontecem (Fahrig 2003). Fragmentos de vegetação mantêm números reduzidos de espécies se comparados a trechos contínuos, pois: (1) constituem um recorte (uma "amostra") da vegetação contínua que, sobretudo em sistemas tropicais, são heterogêneas e com muitas espécies distribuídas em machas; (2) possuem populações pequenas e, portanto, mais 
suscetíveis à extinção local em conseqüência de estocasticidade demográfica e ambiental e do aumento da endogamia; (3) possuem grande extensão de borda exposta a outros ambientes onde as condições ambientais resultam em alterações na estrutura da vegetação, e na composição e dinâmica da biota (Laurance 2008). Se funcionalmente conectados, o conjunto de fragmentos pode manter populações viáveis - em sistemas de metapopulações - e assim um maior número de espécies e comunidades mais semelhantes aos existentes em trechos de vegetação contínua (Hanski 1998, Pardini et al. 2010).

Entretanto, a distribuição das espécies e a manutenção de processos ecológicos dependem não apenas da quantidade e disposição espacial da vegetação remanescente, mas também dos usos da terra que, em conjunto, constituem a matriz de uma paisagem fragmentada (Laurance 2008). Quanto mais similar ao habitat nativo, maior será a probabilidade dos ambientes da matriz: (1) constituírem habitat para espécies nativas; (2) aumentarem a conectividade funcional entre fragmentos de vegetação; e (3) reduzirem a diferença do microclima nas bordas em relação ao interior do fragmento. Os diferentes usos da terra influenciam também a intensidade e distribuição de distúrbios (e.g. ocorrência e expansão de incêndios), a distribuição de espécies invasoras e a pressão humana sobre os sistemas naturais na paisagem (Kupfer et al. 2006). A relevância da matriz de ambientes alterados sobre a resiliência de paisagens modificadas pelo homem tem recebido cada vez mais atenção de cientistas e atores envolvidos no planejamento e manejo do uso da terra (Lindenmayer \& Hobbs 2007) e despertado o interesse sobre usos da terra menos intensivos, que mantém maior biodiversidade associada (Tscharntke et al. 2005).

A intensificação do uso da terra está no centro de uma discussão sobre o planejamento de paisagens visando a conciliação entre produção agrícola e conservação de biodiversidade e serviços ecossistêmicos. Por um lado, sistemas de manejo extensivo (biodiversity- ou wildlife-friendly) podem beneficiar a conservação da biodiversidade ao constituir habitat e promover conectividade entre remanescentes de habitat (Perfecto \& Vandermeer 2008). Por outro lado, sistemas de manejo mais intensivo podem atingir a mesma produção líquida em extensões territoriais menores, e com isso permitem que maiores extensões de terras sejam mantidas com vegetação nativa (Balmford et al. 2005). Ainda que parte dessa questão esteja ligada a cenários sócio-político-econômicos que se adéquam ou conduzem a produções mais ou menos intensivas (Fischer et al. 2008, Vandermeer 2011), a adoção de uma ou outra estratégia deve considerar também características biofísicas das paisagens 
(ex: topografia, qualidade do solo, heterogeneidade espacial dos ecossistemas) e a resposta das espécies às modificações ambientais (Fischer et al. 2008).

Sistemas agroflorestais são usos da terra onde espécies lenhosas estão presentes em uma mesma unidade de manejo com cultivos agrícolas e/ou animais (Somarriba 1992). A manutenção de árvores faz com que esses sistemas exibam condições mais similares às florestas nativas do que outros usos da terra, oferecendo assim possibilidades para conciliar produção e conservação em paisagens florestais fragmentadas (Schroth et al. 2004, Schroth \& Harvey 2007, Perfecto \& Vandermeer 2008). Em regiões tropicais, grandes extensões de florestas nativas foram convertidas em agroflorestas de cacau (Theobroma cacao) e café (Coffea spp.), cultivos que se desenvolvem preferencialmente na sombra (Rice \& Greenberg 2000, Bhagwat et al. 2008). Essas regiões com grandes extensões de agroflorestas oferecem uma oportunidade para a realização de pesquisas que visam avaliar a influência de usos da terra extensivos sobre a diversidade de espécies e processos ecológicos.

Na região sul da Bahia, aproximadamente $6000 \mathrm{~km}^{2}$ de terras já foram ocupados por sistemas agroflorestais destinados à produção de cacau com sombreamento proporcionado por árvores nativas, regionalmente conhecidos como cabrucas (dado para os anos 1996/97; Landau et al. 2008). Parte dessas cabrucas tem sido gradualmente substituída por outros usos da terra ou sistemas de produção mais simplificados, confirmando uma tendência prevista no final da década de 90 (Johns 1999), quando a queda da produtividade das lavouras cacaueiras e do valor do cacau no mercado internacional resultou no abandono de muitas fazendas. No entanto, trechos dessa região que ainda abrigam áreas representativas de cabrucas têm sido alvo de estudos importantes visando o conhecimento da diversidade de espécies e viabilidade de populações nesses agroecossistemas e mosaicos agroflorestais (ex: Pardini et al. 2009, Cassano et al. 2011, Oliveira et al. 2011, Capítulo 1). A grande diversidade de espécies e alto grau de endemismos da floresta Atlântica nesta região, a pressão por parte de movimentos sociais para ocupação de propriedades rurais abandonadas e a necessidade de recuperação da lavoura cacaueira fizeram com que o sul da Bahia fosse também uma área de interesse para o desenvolvimento de projetos de conservação e desenvolvimento agrário por parte de diversas organizações não governamentais.

O presente estudo é fruto de um projeto iniciado em 2006 pelo Instituto de Estudos Socioambientais do Sul da Bahia (IESB) em parceria com a Birdlife International e a 
Sociedade para Conservação das Aves do Brasil (SAVE-Brasil). Esse projeto teve o objetivo de promover práticas agrícolas sustentáveis em propriedades rurais localizadas no Corredor Una-Lontras, região que compreende as terras no entorno e entre duas Unidades de Conservação da região sul da Bahia: a Reserva Biológica de Una e o Parque Nacional das Serras das Lontras. Dentre as práticas incentivadas estavam a recuperação de sistemas agroflorestais destinados à produção de cacau, o fomento à produção orgânica, a averbação de Reserva Legal e o incentivo à criação de Reservas Particulares do Patrimônio Natural. Dado o interesse em incentivar ações que comprovadamente contribuíssem para a conservação da biodiversidade regional, o projeto promoveu também o início de uma compilação de dados científicos e o desenvolvimento de pesquisas que investigassem relações entre o mosaico agroflorestal construído e mantido pelas práticas incentivadas e a diversidade de grupos biológicos, entre eles os mamíferos.

A compilação de dados científicos foi ampliada ao longo do período em que elaborei o plano de pesquisa para o exame de ingresso no programa de pós-graduação em Ecologia, e ao longo do primeiro ano do curso. Com o apoio de pesquisadores da ONG Conservação Internacional (CI-Brasil) e da Universidade Estadual de Santa Cruz (UESC) esta revisão de literatura se transformou num artigo científico, que corresponde ao primeiro capítulo da presente tese de doutoramento. A revisão de literatura foi dividida em três partes. Na primeira, revisamos estudos que comparam a diversidade de espécies das agroflorestas de cacau com outros tipos de vegetação e relacionam as diferenças encontradas com o contexto da paisagem onde esses sistemas se encontram. Em seguida, tratamos dos resultados de estudos que relacionam características locais das plantações (influenciadas pelo manejo) com a disponibilidade de recursos para alguma espécie ou grupo biológico. Por último, focamos nos estudos sobre espécies ameaçadas de extinção e na contribuição das cabrucas para sua conservação. Na discussão, tecemos recomendações para o manejo das plantações de cacau e para os mosaicos agroflorestais e concluímos com a indicação de gargalos de informação e prioridades para estudos futuros.

O estudo dos mamíferos no mosaico agroflorestal teve seu delineamento aperfeiçoado também durante o período em que elaborei o plano de pesquisa para exame de ingresso no programa de pós-graduação em Ecologia e originou os demais capítulos da tese (2 e 3). $\mathrm{O}$ embasamento teórico e a argumentação de ideias desses capítulos receberam contribuições do Dr. Jos Barlow, que se tornou coautor desses capítulos, além da Dr. Renata Pardini, orientadora desta tese. No capítulo 2 construímos hipóteses de como diferentes grupos de 
mamíferos de maior porte devem responder às alterações da estrutura da vegetação, grau de perturbação e disponibilidade de alimento que ocorrem quando florestas são transformadas em cabrucas, e quais as diferenças esperadas para a estrutura, composição e diversidade da assembléia de espécies nos dois sistemas. Testamos nossas hipóteses usando registros fotográficos coletados em nove cabrucas adjacentes a nove remanescentes florestais e partindo de uma lista de espécies conhecidas para a região, que foram previamente classificadas em função do seu hábito alimentar e locomotor e sua vulnerabilidade à caça. No terceiro capítulo, investigamos a importância relativa da cobertura florestal e da intensificação do manejo das cabrucas sobre o uso dessas agroflorestas por mamíferos de maior porte. A distribuição da cobertura florestal no entorno dos sítios de amostragem foi caracterizada por variáveis em duas escalas distintas; o manejo foi descrito por duas medidas da estrutura da vegetação e uma medida da intensidade com que cães domésticos visitam as plantações. Utilizamos registros fotográficos dos mamíferos em 30 cabrucas e uma abordagem de seleção de modelos para contrastar modelos matemáticos que descrevem diferentes relações de importância das variáveis explanatórias. Com o objetivo de testar se falhas na detecção das espécies interferem nos resultados do estudo, comparamos seleções de modelos que consideram a probabilidade de detecção heterogênea e menor do que um contra modelos que não incluem esse parâmetro.

Os três capítulos centrais da tese são apresentados em formato de artigo científico redigidos em inglês. O primeiro artigo foi publicado em 2009 na revista Biodiversity and Conservation e o segundo submetido para a revista Biotropica em 21 de julho de 2011. A tese é composta ainda por uma discussão geral onde discorro brevemente sobre o avanço do conhecimento sobre biodiversidade em agroflorestas, situando a revisão e os estudos empíricos apresentados nessa tese, retomo os principais resultados e conclusões dos três capítulos e exponho questões que podem contribuir para o avanço do conhecimento e aplicação das agroflorestas como ferramenta para conservação.

\section{Referências Bibliográficas}

Balmford, A., R. E. Green, and J. P. W. Scharlemann. 2005. Sparing land for nature: Exploring the potential impact of changes in agricultural yield on the area needed for crop production. Global Change Biology 11: 1594-1605. 
Bhagwat, S. A., K. J. Willis, H. J. B. Birks, and R. J. Whittaker. 2008. Agroforestry: A refuge for tropical biodiversity? Trends Ecol. Evol. 23: 261-267.

Cassano, C. R., M. C. M. KierulfF, and A. G. Chiarello. 2011. The cacao agroforests of the Brazilian Atlantic forest as habitat for the endangered maned sloth Bradypus torquatus. Mammalian Biology 76: 243-250.

Chazdon, R. L., C. A. Harvey, O. Komar, D. M. Griffith, B. G. Ferguson, M. Martinez-Ramos, H. Morales, R. Nigh, L. Soto-Pinto, M. van Breugel, and S. M. PHILPOTT. 2009. Beyond reserves: A research agenda for conserving biodiversity in human-modified tropical landscapes. Biotropica 41: 142-153.

EHRLICH, P. R. 2007. Landscape in peril. In: D. B. Lindenmayer and R. J. Hobbs (Eds.). Managing and Designing Landscapes for Conservation: Movimg from Perspectives to Principles. Blackwell Publishing Ltd, Malden, MA, pp. xi-xvi.

FAHRIG, L. 2003. Effects of habitat fragmentation on biodiversity. Annual Review of Ecology Evolution and Systematics 34: 487-515.

Fischer, J., B. Brosi, G. C. Daily, P. R. Ehrlich, R. Goldman, J. Goldstein, D. B. Lindenmayer, A. D. Manning, H. A. Mooney, L. Pejchar, J. Ranganathan, and H. TALLIS. 2008. Should agricultural policies encourage land sparing or wildlifefriendly farming? Frontiers in Ecology and the Environment 6: 382-387.

Foley, J. A., R. DeFries, G. P. Asner, C. Barford, G. Bonan, S. R. Carpenter, F. S. Chapin, M. T. Coe, G. C. Daily, H. K. Gibbs, J. H. Helkowski, T. Holloway, E. A. Howard, C. J. Kucharik, C. Monfreda, J. A. Patz, I. C. Prentice, N. RAMANKUTTY, and P. K. SNYDER. 2005. Global consequences of land use. Science 309: 570-574.

Gardner, T. A., J. Barlow, R. Chazdon, R. M. Ewers, C. A. Harvey, C. A. Peres, and N. S. SoDHI. 2009. Prospects for tropical forest biodiversity in a human-modified world. Ecol. Lett. 12: 561-582.

Gardner, T. A., J. Barlow, N. S. Sodhi, and C. A. Peres. 2010. A multi-region assessment of tropical forest biodiversity in a human-modified world. Biol. Conserv. 143: $2293-2300$.

HANSKI, I. 1998. Metapopulation dynamics. Nature 396: 41-49. 
JoHns, N. D. 1999. Conservation in Brazil's chocolate forest: The unlikely persistence of the traditional cocoa agroecosystem. Environ. Manage. 23: 31-47.

Kupfer, J. A., G. P. Malanson, and S. B. Franklin. 2006. Not seeing the ocean for the islands: the mediating influence of matrix-based processes on forest fragmentation effects. Global Ecology and Biogeography 15: 8-20.

Landau, E. C., A. Hirsch, and J. MusinKy. 2008. Vegetation cover and land use in the Atlantic forest of southern Bahia, Brazil, based on satellite imagery: a comparison among municipalities. In: W. W. Thomas and E. G. Britton (Eds.). The Atlantic Coastal Forest of Northeastern Brazil. The New York Botanical Garden Press, New York, NY, pp. 221-244.

LAURANCE, W. F. 2007. Have we overstated the tropical biodiversity crisis? Trends Ecol. Evol. 22: 65-70.

LAURANCE, W. F. 2008. Theory meets reality: How habitat fragmentation research has transcended island biogeographic theory. Biol. Conserv. 141: 1731-1744.

Lindenmayer, D., R. J. Hobbs, R. Montague-Drake, J. Alexandra, A. Bennett, M. Burgman, P. Cale, A. Calhoun, V. Cramer, P. Cullen, D. Driscoll, L. Fahrig, J. Fischer, J. Franklin, Y. Haila, M. Hunter, P. Gibbons, S. Lake, G. Luck, C. MacGregor, S. Mcintyre, R. Mac Nally, A. Manning, J. Miller, H. Mooney, R. Noss, H. Possingham, D. Saunders, F. Schmiegelow, M. Scott, D. Simberloff, T. Sisk, G. TABOr, B. WALKER, J. Wiens, J. WoinARSKi, and E. Zavaleta. 2008. A checklist for ecological management of landscapes for conservation. Ecol. Lett. 11: 78-91.

Lindenmayer, D. B., and R. J. HobBS. 2007. Managing and Designing Landscapes for Conservation: Movimg from Perspectives to Principles. Blackwell Publishing Ltd, Malden, MA.

Millenium Ecosystem Assessment. 2005. Ecosystems and Human Well-being: Biodiversity Synthesis. World Resources Institute, Washington, DC.

Oliveira, L. C., L. G. Neves, B. E. Raboy, and J. Dietz. 2011. Abundance of jackfruit (Artocarpus heterophyllus) affects group characteristics and use of space by goldenheaded lion-tamarins (Leontopithecus chrysomelas) in cabruca agroforest. Environ. Manage. 48: 248-262. 
Pardini, R., A. D. Bueno, T. A. Gardner, P. I. Prado, and J. P. Metzger. 2010. beyond the fragmentation threshold hypothesis: Regime shifts in biodiversity across Fragmented landscapes. Plos One 5: e13666.

Pardini, R., D. Faria, G. M. Accacio, R. R. Laps, E. Mariano-Neto, M. L. B. Paciencia, M. DiXo, and J. BAumgarten. 2009. The challenge of maintaining Atlantic forest biodiversity: A multi-taxa conservation assessment of specialist and generalist species in an agro-forestry mosaic in southern Bahia. Biol. Conserv. 142: 1178-1190.

Perfecto, I., and J. VAndermeer. 2008. Biodiversity conservation in tropical agroecosystems - A new conservation paradigm. Ann. N.Y. Acad. Sci. 1134: 173-200.

Rice, R. A., and R. GreEnBERG. 2000. Cacao cultivation and the conservation of biological diversity. Ambio 29: 167-173.

Sala, O. E., F. S. Chapin, J. J. Armesto, E. Berlow, J. Bloomfield, R. Dirzo, E. Huber-Sanwald, L. F. Huenneke, R. B. Jackson, A. Kinzig, R. Leemans, D. M. Lodge, H. A. Mooney, M. Oesterheld, N. L. Poff, M. T. Sykes, B. H. Walker, M. WALKER, and D. H. WALL. 2000. Biodiversity - Global biodiversity scenarios for the year 2100. Science 287: 1770-1774.

Schroth, G., G. A. B. FONSECA, C. A. Harvey, C. Gascon, H. L. Vasconcelos, and A. M. N. IZAC. 2004. Agroforestry and biodiversity conservation in tropical landscapes. Island Press, Washington, DC.

Schroth, G., and C. A. HARvey. 2007. Biodiversity conservation in cocoa production landscapes: An overview. Biodiversity Conserv. 16: 2237-2244.

SOMARribA, E. 1992. Revisiting the Past - An Essay on Agroforestry Definition. Agroforestry Systems 19: 233-240.

Tscharntke, T., A. M. Klein, A. Kruess, I. Steffan-Dewenter, and C. Thies. 2005. Landscape perspectives on agricultural intensification and biodiversity - Ecosystem service management. Ecol. Lett. 8: 857-874.

VAndermeer, J. 2011. The Ecology of Agroecosystems. Jones and Barlett Publishers, Sudbury, MA. 


\section{Landscape and farm scale management to enhance biodiversity conservation in the cocoa producing region of southern Bahia, Brazil}

Camila R. Cassano, Götz Schroth, Deborah Faria, Jacques H.C. Delabie and Lucio Bede

Publicado na revista Biodiversity and Conservation, 18: 577-603 (2009) 


\begin{abstract}
In southern Bahia, Brazil, large land areas are used for the production of cocoa (Theobroma cacao), which is predominantly grown under the shade of native trees in an agroforestry system locally known as cabruca. As a dominant forest-like landscape element of the cocoa region, the cabrucas play an important role in the conservation of the region's biodiversity. The purpose of this review is to provide the scientific basis for an action plan to reconcile cocoa production and biodiversity conservation in southern Bahia. The available research collectively highlights the diversity of responses of different species and biological groups to both the habitat quality of the cabrucas themselves and to the general characteristics of the landscape, such as the relative extent and spatial configuration of different vegetation types within the landscape mosaic. We identify factors that influence directly or indirectly the occurrence of native species in the cabrucas and the wider landscape of the cocoa region and develop recommendations for their conservation management. We show that the current scientific knowledge already provides a good basis for a biodiversity friendly management of the cocoa region of southern Bahia, although more work is needed to refine some management recommendations, especially on shade canopy composition and density, and verify their economic viability. The implementation of our recommendations should be accompanied by appropriate biological and socioeconomic monitoring and the findings should inform a broad program of adaptive management of the cabrucas and the wider cocoa landscape.
\end{abstract}

Keywords: Atlantic forest; biodiversity; cabruca; cocoa agroforest; connectivity; fragmentation; landscape management; Theobroma cacao 


\subsection{Introduction}

In the face of high rates of tropical forest loss, agroforestry based development models have been proposed as a strategy to conserve natural resources in the tropics (Izac \& Sanchez 2001, Schroth et al. 2004). The cocoa tree (Theobroma cacao L., Malvaceae) is traditionally planted in several tropical regions under a native tree canopy after thinning the original forest (Rice \& Greenberg 2000, Ruf \& Schroth 2004). Cocoa plantations shaded by native trees are reportedly among the agroforestry practices with greatest potential to reconcile agricultural development and biodiversity conservation (Rice \& Greenberg 2000, Schroth et al. 2004, Schroth \& Harvey 2007). This is particularly relevant in southern Bahia, Brazil's main cocoa production region. Together with the northern part of the state of Espírito Santo, this region forms a center of species endemism within the Atlantic forest biome, where co-generic species from the Amazon forest and from the southern Atlantic forest are found (Brown Jr. 1982, Thomas et al. 1998). The region is exceptional for its biodiversity, and in a recent comparison of tree diversity in 22 tropical forests around the world, a forest remnant in southern Bahia was the second richest site (Martini et al. 2007). Tree endemism can exceed 25\% (Thomas et al. 1998). The region also harbors several endemic species of mammals, birds (Bencke et al. 2006) and ants (Delabie et al. 1998, Lacau et al. 2004). However, a recent study estimated that only $6.5 \%$ of old growth forest remains in southern Bahia, with few remnants larger than 1000 hectares (Landau 2003).

The cocoa region of southern Bahia is defined here as the area between the Contas and Jequitinhonha Rivers (Figure 1). Cocoa cultivation began here in the eighteenth century and peaked in the 1960s and 1970s. Over the following decades, the government's Executive Commission of the Cocoa Production Plan (CEPLAC) recommended establishing cocoa plantations by felling all native trees followed by planting cocoa seedlings together with bananas and erythrinas (Erythrina fusca - an exotic legume with no economic value) as shade trees. However, the lower cost of establishing cocoa groves in the traditional system - partial thinning of the forest and its under-planting with cocoa trees - resulted in the formation of extensive agroforests, known as cabrucas (Alger \& Caldas 1994, Johns 1999; Figure 2). According to Sambuichi (2006), native tree density in cabrucas ranges from 35 to 173 trees per hectare and reaches 355 trees per hectare in abandoned plantations with their vigorous regeneration especially of pioneer species. 
In the late 1980s, cocoa cultivation in Bahia entered into a period of decline triggered by falling international cocoa prices and the spread from the Amazon into Bahia of the fungus Moniliophthora perniciosa, causal agent of the "witches' broom" disease. The loss of cocoa income led many growers to sell off their shade trees for timber (Alger \& Caldas 1994, Araújo et al. 2007), while others abandoned their plantations. However, cocoa farms still occupy approximately $6000 \mathrm{~km}^{2}$ in southern Bahia (Landau 2003), many of which are abandoned or very extensively managed. Current recommendations by CEPLAC on techniques to rehabilitate cocoa plantations include the grafting of witches' broom resistant cocoa varieties on diseased trees and the replacement of the erythrina shade trees with rubber trees (Hevea brasiliensis) in order to increase and diversify farm income (Marques \& Monteiro 2006).

Research in southern Bahia and other cocoa producing regions, especially Central America and parts of Africa, has shown that a significant part of the extant native flora and fauna can be conserved in traditional cocoa agroforestry systems (e.g. Rice \& Greenberg 2000, Delabie et al. 2007, Faria et al. 2007, Schroth \& Harvey 2007). For example, traditional cocoa agroforests with diversified native shade trees were shown to harbor a richer bird, bat and dung beetle fauna than plantain monocultures in Costa Rica (Harvey et al. 2006, Harvey \& Villalobos 2007) and a richer ant fauna than pasture in Bahia (Delabie et al. 1999). However, these studies have also demonstrated that the contribution of cocoa agroecosystems to the conservation of biodiversity is dependent on their structure, composition and management, as well as on the quantity, quality and location of remnants of native forest habitat in the landscape (Schroth \& Harvey 2007). Furthermore, there is considerable variation between species groups of conservation concern in Bahia with regard to their ability to utilize shaded cocoa plantations as habitat and to persist in the wider cabruca landscape (e.g. Alves 1990, Pardini 2004, Faria et al. 2007). Understanding how different elements of the local biota are influenced by site and landscape features is a necessary step for the design of conservation actions.

This article reviews the available information about the biodiversity of cocoa plantations and their landscape context in southern Bahia and identifies recommendations for management actions to improve its conservation. We first review studies that compare the biodiversity of shaded cocoa plantations with that of other vegetation types in the landscape and relate it to the composition of the landscape as a whole. Subsequently, we discuss the specific management of shaded cocoa plantations in relation to patterns of 
biodiversity at the site scale. We then focus specifically on endangered species of the region and highlight the contribution that cabrucas can make to their conservation. In the discussion we derive recommendations for the conservation management both of cocoa plantations and the wider landscape in southern Bahia, many of which are also applicable in other cocoa regions. We conclude with some research needs.

\subsection{Methods}

Our information sources were publications in scientific journals as well as reports, Master and Doctoral theses from several Brazilian universities. We also review studies presented at the "First Symposium on the Cocoa Production Landscape and Biodiversity of Southern Bahia" that took place at the State University of Santa Cruz, Ilhéus, Bahia, on October 8 and 9, 2007. A significant part of the body of research we present here is not available in the peer reviewed scientific literature. From a total of 52 scientific studies, we extracted information on the following biological groups: vertebrate fauna (mammals, birds, reptiles and amphibians); invertebrate fauna (butterflies, ants and parasitoids); and flora (trees, ferns and bromeliads). The geographic range of the studies varies from one or a few sites to the entire Bahian cocoa region. Most research was carried out in the counties of Una, Ilhéus and Itabuna, due in part to the location of the main cocoa research institutions there (CEPLAC, University of Santa Cruz) and in part to the importance of cocoa production for these counties. The paucity of information on most of the biological groups as well as differences between studies in survey methods prevented a formal meta-analysis.

\subsection{Results}

\section{The biodiversity of shade cocoa plantations within the landscape}

A main focus of biodiversity research in the cocoa region has been the county of Una surrounding the Una Biological Reserve, which was established in 1980 and is now one of the largest remaining forest blocks in the region (currently 11,000 hectares). The area is still dominated by mature forest remnants (50\% of the landscape) interspersed with secondary forests (15\%) and cabrucas (5\%), the remainder being mostly open pastures, crop fields and small plantations (Figure 1). Between 1998 and 2002, researchers of the RestaUna project (http://www.restauna.org.br/) coordinated by the State University of Santa Cruz (UESC), Ilhéus, conducted an inventory of the fauna and flora of the edges and 
interior of large (>1000 ha) and small forest fragments $(<200 \mathrm{ha})$, as well as the cabrucas and secondary forests which dominate the surrounding matrix. For the purpose of the study, the latter habitat was defined as at least 15 year old forest regrowth after complete clearing of a site. This research revealed the high diversity of assemblages of all investigated biological groups (small mammals, bats, birds, leaf-litter frogs and reptiles, frugivorous butterflies, ferns and bromeliads) in the cabrucas and secondary forests, with species richness and abundance values comparable to those in the interior of mature forest fragments. There were, however, changes in the species composition and relative abundance of different species within each group, indicating an idiosyncratic response of each biological group to the alterations in the landscape that cocoa growing and other landuses had brought about (Table 1). Here we summarize the salient results for each taxonomic group.

Small mammals: For small mammals, the abundance of terrestrial and scansorial species that dominate the communities of the forest interior (Oryzomys laticeps, Marmosops incanus and Monodelphis americana) showed a relative decrease, while the abundance of three arboreal species (Marmosa murina, Rhipidomys mastacalis and Micoureus demerarae) increased in the disturbed habitats, i.e. forest edges, cabrucas and secondary forests. Two species that are typical of open environments, Oligoryzomys sp. and Akodon cursor, were found in the three disturbed habitats but were rare or absent from the forest interior (Pardini 2004). Possibly the increased richness of terrestrial small mammals in the disturbed habitats, including the cabrucas, narrowed the niche for the corresponding forest interior species through competition, but did not affect arboreal species (Pardini 2001).

Bats: Faria (2006), Faria et al. (2006), Faria \& Baumgarten (2007) showed that the richness and abundance of bats were higher in cabrucas than in natural forest. This was even true for gleaning insectivores, a feeding guild usually regarded as sensitive to habitat fragmentation (Fenton et al. 1992) and disturbance (Medellin et al. 2000). Rhinophylla pumilio, a dominant bat species in large forest remnants that is considered vulnerable to fragmentation (Henry \& Kalko 2007) was the only species whose capture frequency was lower in cabrucas, where Carollia perspicillata, the second most abundant species in the large forest remnants, was the dominant species. This contrasting response of $R$. pumilio and C. perspicillata to cabruca versus forest was confirmed in the neighboring county of Ilhéus that is much poorer in forest and richer in cabrucas than Una (Faria et al. 2006). In Una, bat abundance and richness were inversely correlated to the understory density of 
forest patches (Faria 2002), suggesting that the simpler vegetation structure in cabrucas facilitated their flight (Faria et al. 2006, Faria \& Baumgarten 2007). This open understory may also explain why bat species that normally use the forest canopy, such as Artibeus jamaicencis, A. lituratus, Chiroderma villosum and Phyllostomus hastatus, were caught in mist nets at 1-2 $\mathrm{m}$ above the ground in cabrucas. In another study in neighboring Ilhéus, Artibeus obscurus, a forest-dwelling species negatively affected by decreasing fragment size in the Una region (Faria 2006), was more abundant in cocoa plantations than in forest irrespective of their distance to forest and canopy cover, presumably due to the greater density of fruit trees such as Ficus spp. on which they feed (Farias \& Faria 2007).

Avifauna: In forest-rich Una, six typical forest bird species - the understory insectivores Drymophila squamata, Herpsilochmus pileatus, Pyriglena leucoptera, Rhytipterna simplex and the terrestrial insectivores Conopophaga melanops and Formicarius colma - were less abundant in cabrucas than in forest and one forest bird (Lipaugus vociferans, an understory frugivore) was absent from cabrucas (Faria et al. 2006). For birds, cabrucas seem to be transitional habitat where species typical of forest, fragment edges and open areas occur together, with the latter probably benefiting from the simpler vegetation structure (Faria et al. 2006).

Leaf-litter herpetofauna: Dixo (2001) found no differences in total species richness or abundance of litter frogs and lizards between cabrucas and forest fragments between 25 and $>1000$ ha in size in Una, but reported significant differences in the abundance of two lizard species, with greater abundance of Leposoma scinconoides and lower abundance of Enyalus catenaci pictus in cabrucas than forest. The latter species was also less abundant in secondary than in primary forest. (It should be mentioned that many species found in both habitats were rare and it is generally difficult to find significant differences for such species.)

Nymphalid butterflies: The cabrucas of Una harbored fewer species of the Morphinae subfamily than forest fragments between 25 and $>1000$ ha in size and the abundance of two species from the Brassolinae sub-family, Caligo idomenaeus and Eryphanis polyxena, tended to be lower in cabrucas than in these forest fragments. Large forest species from the Euritelinae, Coloburinae and Satyrinae sub-families showed no difference in species richness between cabrucas and forest. Cabrucas seemed to be inhospitable to some of the species that are considered invaders of disturbed areas in the region (such as Biblis hyperia 
and Caligo illioneus), and only Yphtimoides reneta and Hermeuptychia hermes from this group were found in significant numbers (Accacio 2004).

Ferns and bromeliads: The fern communities of cabrucas in Una were poorer in numbers of species than forest interiors and some species (including those of the Hymenophyllaceae family) were missing. On the other hand, cabrucas were suitable for other typical forest ferns, such as Adiantum diogoanum, as well as fern species typical of disturbed habitat (Paciencia \& Prado 2004, 2005a, 2005b). The discovery of a new species of fern, Adiantum discolor, in a cabruca during this study (Prado 2000) highlights the importance of these agroforests for biodiversity conservation. Epiphytic bromeliads were significantly less abundant and less species rich in cabrucas than in forest fragments (both interior and edge; Alves 2005). Understory bromeliads from the forest interiors were found to be heavily affected by the conversion of forest to cabrucas: from nine species reported in the interiors of forest fragments (Aechmea mollis, A. turbinocalyx, Areococcus paviflorus, Lymania globosa, L. azurea, L. south bahiai, Nidularium amorimii, Vriesea drepanocarpa and $V$. duvaliana) none was found in cabrucas. All except the latter two of these species are endemic to the Atlantic Forest of southern Bahia and northern Espírito Santo. Three bromeliad species from the forest canopy (Aechmea conifera, A. leonard-kentiana and Aechmea sp.) were either absent or very rare in cabrucas, while another four canopy species (Aechmea lingulata, Honhenbergia brachycephala, Vriesea sp. and V. procera) were found exclusively in cabrucas. The most abundant bromeliad species in cabrucas was Aechmea lingulata whose large range stretches from Central America to southeast Brazil (Alves 2005).

The research reviewed thus far, most of which was carried out under the umbrella of the RestaUna project, thus showed that the cabrucas of forest-rich Una are highly species diverse, harboring about $70 \%$ of the 431 species of ferns, frugivorous butterflies, litter frogs and lizards, small mammals, birds and bats that were found in all vegetation types (including mature forest) together in this project.

In subsequent work, the same biological groups except for bromeliads were surveyed in primary forest remnants and cabrucas about $30-40 \mathrm{~km}$ further north in the county of Ilhéus (Figure 1). Although the forests of Una and Ilhéus originally belonged to a single block before the agricultural transformation of the region, the two landscapes are now markedly different. While cabrucas occupy $5 \%$ and forest $50 \%$ of the Una landscape, the landscape of Ilhéus is dominated by cabrucas ( $82 \%)$ with only $5 \%$ under forest. 
Overall, the biological communities were poorer in the cabruca-dominated landscape of Ilhéus than in the forest-dominated landscape of Una, with fewer species of small mammals (Ortiz et al. 2002), bats (Faria et al. 2006, Faria \& Baumgarten 2007), birds (Faria et al. 2006), ferns, and litter herpetofauna (Faria et al. 2007; Figure 3). This suggests that despite the relatively high habitat quality of the cabrucas that dominate the landscape, the amount of natural habitat remaining in the Ilhéus landscape is too low to retain completely the original species assemblages. Also, a greater variation in bird communities between individual forest fragments was observed in forest-poor Ilhéus than in forest-rich Una, suggesting that the connectivity provided by the cabrucas between forest fragments may be insufficient to allow rapid recolonization of fragments following local extinctions (Faria et al. 2007).

The important contribution of the cabrucas and the vital role of forest remnants for maintaining the region's biodiversity also emerge from other research. In a study by Alves (1990), the species richness of medium and large sized birds and mammals was greater in two cabrucas close to large forest remnants than in cabrucas that were distant from forest fragments, suggesting that the forest remnants served as a refuge for these animals. In this study, typical understory birds of the Formicaridae and Pipridae families were less common in cabrucas than in forest while ground-dwelling species of the Cracidae and Tinamidae families where almost absent, confirming that cabrucas offer habitat for some but not all forest birds. Among mammals, the collared peccary (Pecari tajacu), deer (Mazama sp.) and two large primates (the yellow-breasted capuchin monkey, Cebus xanthosternos, and the southern Bahian masked titi monkey, Callicebus melanochir) were rarely recorded in cabrucas, while small primates (Wied's black-tufted-ear marmoset, Callithrix kuhlii, and the golden-headed lion-tamarin, Leontopithecus chrysomelas) as well as generalist species such as tayra (Eira barbara) and crab-eating raccoon (Procyon cancrivorus) were more common. Alves (1990) reported that the occurrence of $L$. chrysomelas in cabrucas was positively related to the proximity of forest remnants and their size. These observations are supported by a camera-trap study where golden-headed lion-tamarins were recorded in five out of 20 cabrucas and in five out of seven forest fragments, with all cabrucas that harbored tamarins being close to forest remnants (Cassano 2007). On the other hand, groups of lion tamarins that live continuously in cabrucas without access to forest are also known (Leonardo Oliveira, pers. com. 2008). In another study comparing cabrucas, secondary forests and young fallows throughout the 
region, Neves et al. (2007) recorded C. kuhlii and L. chrysomelas in all three habitats (the two species were found in, respectively, $72 \%$ and $32 \%$ of the cabrucas visited), but did not find large-sized primate species such as howler monkey (Alouatta guariba) and yellowbreasted capuchin monkey in cabrucas.

Deforestation and the increase in cultivated areas in the southern Bahian landscape were suggested as causal factors in the replacement of the leafcutter ant, Atta cephalotes, a typical species of forest environments, by Atta sexdens, a species more typical of degraded areas in this region (Delabie 1990, Delabie et al. 1999, Delabie et al. 2007). Forest loss is also held responsible by these authors for the replacement of some ant genera previously recorded in cabrucas, such as the decrease in abundance of species of the Ponerinae and Ecitoninae sub-families and the concomitant increase in species of the Formicinae and Dolichoderinae. According to Delabie et al. (2007), several species of army ants of the genus Eciton can be found in cabrucas, provided there are contiguous forest remnants to maintain their colonies. Open areas, such as pastures and clearings, are barriers to foraging for some army ant species. A predictable consequence of the decline in army ants (Eciton and Neivamyrmex) in the cocoa region would be the disappearance of their associated fauna, especially ant birds (Delabie 1990, Delabie et al. 2007) and many invertebrates that benefit from the niches created by the periodic elimination of litter fauna along ant trails (Franks 1989).

\section{Biodiversity conservation and cocoa management within the cabruca system}

The conversion of forest into cabrucas implies a major alteration of plant species composition and forest structure, including the clearing of the forest understory which hosts most of the forest plant species (Martini 2007) and the loss of over $90 \%$ of the overstory trees (Alves 1990). Nevertheless, botanical surveys in cabrucas have found large numbers of native canopy tree species, including timber species such as Cedrela odorata, Nectandra sp. and Cariniana spp. that have become rare in unprotected natural forest due to over-use (Vinha \& Silva 1982, Sambuichi 2002, 2006, Lobão 2007). For example, Sambuichi \& Haridasan (2007) found 293 morpho-species of trees in five cabrucas in Ilhéus county, and Rolim \& Chiarello (2004) inventoried 105 species in a cabruca in the neighboring state of Espírito Santo. Considering the extremely high tree diversity of southern Bahia (Thomas et al. 1998), this is an important conservation service provided by 
cabrucas. However, common management practices in cabrucas tend to decrease tree diversity over time. These include the progressive thinning of shade canopies - partly motivated by official recommendations to keep only 25-30 trees per hectare to maximize cocoa yields (Alvin 1966, Alvin \& Pereira 1970) - and the substitution of old forest trees typically climax and late secondary species - by faster growing pioneer and economically valuable species, often exotics (Sambuichi 2006, Mota et al. 2007, Sambuichi \& Haridasan 2007). The reduction of shade tree density and diversity is likely to negatively affect habitat conditions for many fauna species that depend on the microclimate, food and other habitat conditions created by the shade canopy, although this relationship has not been well studied. For example, shade trees in cabrucas provide food for fruit and nectar-eating bats (Faria \& Baumgarten 2007) and can be used for displacement and food by two endangered arboreal mammals, the golden-headed lion-tamarin (Leontopithecus chrysomelas) and the maned three-toed sloth (Bradypus torquatus; see following section). Greater diversity of shade trees in cocoa plantations was also positively related to parasitoid richness and abundance and thus supported natural pest control (Sperber et al. 2004).

Common management practices of cabrucas also impact herbaceous and understory plant species. According to Martini (2007), approximately two thirds of the plant species in forest fragments in southern Bahia are understory species. Except for species that re-sprout after cutting, these species are eliminated by the establishment and periodic weeding of cocoa plantations, and therefore depend on natural forest areas for their conservation. Like canopy trees, understory plants are also an important basis for fauna species in cabrucas. Heliconias and a large number of Marantaceae, which resprout between weedings, account for the diversity and abundance of small butterflies of the Satyrinae sub-family in the cabrucas of Una (Accacio 2004). The leaves of Heliconia spp. in cabrucas are also used as shelter by bats (e.g. Thyroptera tricolor), while other bat species use termite nests and tree holes (e.g. Lophostoma sivicolum nests in active termite hills; Faria \& Baumgarten 2007). According to Faria et al. (2007), epiphytic ferns are less abundant in cabrucas than in forest, possibly because they are removed from the trees by farm workers. The pruning of cocoa trees and removal of epiphytes from their stems and branches are part of the normal cocoa management and may reduce the diversity of epiphytes in the cabruca understory (Alves 2005). Micro-climatic modifications such as lower atmospheric humidity and lack of suitable dispersers probably also reduce the richness of the bromeliad flora in cabrucas, 
although some species with a high vegetative reproduction capacity seem to do well (Alves 2005).

The suspended soil in the shade canopies of cabrucas provides a rooting substrate for bromeliads and other epiphytes (Figure 4) and thus helps to maintain a rich fauna of ant species that are either arboreal or normally live in the litter layer, in addition to many other invertebrate species (Delabie 2003). Cocoa plantations shaded by Erythrina sp. are considered good ant habitat because the architecture of these leguminous trees favors the development of a great number of epiphytes (J.H.C. Delabie, per. obs.). The same can be said for tree snakes that use epiphytes as shelter and feeding sites (A.J.S. Argôlo, pers. com. 2007).

The lower abundance or even absence of understory birds and small arboreal mammals in cabrucas compared to forest can partly be explained by differences in vegetation structure, especially the simplification of the understory and absence of connecting vines between understory and tree canopies (Alves 1990, Moura 1999, Faria et al. 2006). Cassano \& Moura (2003) found a possible relationship between vegetation structure and small mammal diversity among cocoa plantations. They recorded five small mammal species in the simplified environment of a cocoa plantation shaded by rubber trees (Hevea brasiliensis, Euphorbiaceae) with complete suppression of the herbaceous stratum; seven species in a similar plantation where the herbaceous stratum was maintained; and 12 species in a cabruca with complex shade canopy whose understory had not been slashed for three years. The structural complexity of the vegetation was also suggested by Pinto et al. (1993) to be a determinant of the richness and abundance of small mammals in a comparison of native forest, an oil palm plantation, a cocoa plantation shaded by rubber trees, and a cabruca.

Majer et al. (1994)found that arboreal ant communities in the understory of three cocoa plantations shaded by erythrinas showed stronger dominance of species of the genera Azteca, Ectatomma or Crematogaster than the understory of a cabruca, despite similar overall ant diversity. They explained the difference with greater diversity of the shade canopy, greater plantation age and no insecticide use in the cabruca. The cabruca was the only of the four plantations where the "little fire ant" Wasmannia auropunctata was not recorded. This species shows great capacity for population growth and colonization of new areas where other ant species were eliminated by insecticides (Delabie 1990). Insecticide use and the removal of nests of social ants in cabrucas are held responsible for the 
replacement of ants of the genus Solenopsis and, in the tree stratum, Azteca spp. by $W$. auropunctata (Delabie 1990). In a more recent study, Delabie et al. (2007) showed that W. auropunctata has a common but discrete presence in forest remnants where it is limited to small populations in the litter stratum, while in cocoa plantations it colonizes the tree canopies to raise sucking insects and excludes other ant species. Delabie et al. (2007) emphasized the importance of maintaining an intact litter layer in cocoa plantations because, similar to forest, this stratum concentrates the highest ant diversity. Pruning of the cocoa canopies and the reduction of their height to control infestations by the witches' broom disease are singled out for their negative effect on the arboreal ant communities which consequently cease to play their role in the biological control of herbivorous insects that damage the cocoa trees (Delabie \& Mariano 2001, Delabie et al. 2007). The same authors suggested that the rarity of the forest ant Typhlomyrmex rogenhoferi in cocoa plantations in southern Bahia is a consequence of the rarity of fallen tree trunks where these ants build their nests (Delabie et al. 2007).

\section{Contribution of cabrucas to the conservation of endangered species}

Cabrucas provide habitat and resources to several endangered endemic species of the Atlantic forest and should therefore be considered in action plans for their conservation.

Mammals: At least two endangered mammal species have been recorded in cabrucas: the golden-headed lion-tamarin (Leontopithecus chrysomelas; Alves 1990, Raboy et al. 2004, Cassano 2007, Neves et al. 2007) and the maned three-toed sloth (Bradypus torquatus; Cassano 2006). Two groups of lion-tamarins that were monitored in the Una Biological Reserve used a nearby cabruca in their daily activities and as sleeping sites (Raboy et al. 2004). The tamarins preferentially used tree holes as shelter and the greater frequency of suitable holes seemed to be a reason why they slept more often in mature forest than in secondary forest and cabrucas (Raboy et al. 2004). Oliveira et al. (2007) listed 118 tree species used by these same groups of lion tamarins in the Una Biological Reserve between 1998 and 2006, with 80 species being used for food and 63 species as sleeping sites. Such information on preferred tree species could be used for improving the habitat quality of cabrucas and other farm areas for this endangered primate (and similarly other fauna species), thereby contributing to their more effective conservation. In addition, bromeliads of the genus Aechmea, including A. conifera and A. cf. depressa, were used as food and 
foraging sites by the tamarins (Nascimento et al. 2007) and were their main food item in abandoned cabrucas in the Una Biological Reserve (Catenacci 2008).

Cassano (2006) monitored a female maned three-toed sloth, Bradypus torquatus, an endemic species of the Atlantic forest, and its offspring in a cabruca near the Una Biological Reserve. The sloths used the cabruca, which had an unusually dense canopy, as their main habitat and the most abundant tree species in the shade canopy were part of their diet (Correia et al. 2006, Barreto \& Cassano 2007).

The cocoa region of southern Bahia is also the main area of occurrence of the endemic painted tree rat, Callistomys pictus. The cabrucas are probably important habitat for this rodent given that they are the main environment where the species has recently been recorded. Hollow trees and epiphytic bromeliads are apparently used as shelter. Cocoa leaves and fruits are consumed, but the species does not appear to cause significant economic damage (Moura 2005, 2008). However, this rodent is being captured and killed by farm workers, suggesting a need for local education programs to enhance the conservation of the species.

Birds: Faria et al. (2006) reported the occurrence of the pileated antwren (Herpsilochmus pileatus) in cabrucas both in the forest-dominated Una and the cabruca-dominated Ilhéus counties. However, in the latter area the species was very rarely found, indicating that despite its ability to utilize cabrucas it is vulnerable to forest loss in a landscape-scale. The cabrucas between Camacan and Itabuna are considered the main area of occurrence of the acrobat bird (Acrobatornis fonsecai), a species that was first discovered and described in a cabruca (Pacheco et al. 1996). Most of the subsequent recordings of the species are also linked to the cabruca environment and Pacheco et al. (1996) believe that the conversion of natural forest into cabrucas may have actually contributed to a widening of its range, including to altitudes of up to $600 \mathrm{~m}$. The acrobat bird is a canopy species and observations have indicated that it forages in mixed flocks, feeding mainly on insects and nesting preferentially in legume trees which are common in cabrucas. The species has recently been reported from cabrucas near the Una Biological Reserve (André de Luca, pers. com. 2007) and in the Ilhéus area (Faria et al. 2006).

Invertebrates: Cabrucas may also play a role in invertebrate conservation. The ant Dinoponera lucida is on the list of Brazilian fauna threatened with extinction. It is found in the southern part of the cocoa region, including in cocoa plantations adjacent to forest 
remnants, indicating that, as a minimum, cabrucas can facilitate species dispersion among forest remnants (Delabie et al. 2007). On the other hand, the rare endemic ant species, Blepharidatta sp. n., has been found in forest areas through much of the cocoa region, but only a single encounter in a cabruca has so far been reported (Figure 1). These ants are exceptional by not having winged forms and thus depend on suitable habitat for their dispersal. If it is true that cabrucas do not provide suitable habitat, then these ants would be severely threatened by forest fragmentation (J.H.C. Delabie, unpublished data).

While several endangered species of mammals, birds and invertebrates of the region use cabrucas as (secondary) habitat, for others these agroforests do not seem to offer suitable conditions. Two endangered primates of the region, the yellow-breasted capuchin monkey (Cebus xanthosternos) and the Southern Bahian masked titi monkey (Callicebus melanochir), as well as the bristle-spined porcupine (Chaetomys subspinosus), do not seem to enter cabrucas (Alves 1990, Giné et al. 2006, Neves et al. 2007), reinforcing again the complementarity of forest conservation and the conservation of cabrucas in an integrated landscape management strategy. Still, cabrucas may benefit these species indirectly by helping to maintain vital ecological processes, including maintaining prey species and reducing edge effects in forest fragments.

\subsection{Discussion and recommendations}

\section{Landscape management in southern Bahia cocoa region}

Research in the cocoa region of southern Bahia has shown that although cabrucas are suboptimal habitat for many typical forest species, they can to some extent mitigate the fragmentation and loss of natural habitat for a significant part of the regional biota. In the forest-rich landscape of Una, small forest remnants $(<200$ ha $)$ have biological communities as rich and abundant as the large forest blocks, suggesting that the cabrucas pose no obstacle to the movements of forest species through the landscape. In the forestpoor landscape of Ilhéus, on the other hand, the cabrucas that dominate the landscape provide habitat for many species while the remaining forest fragments are essential for those species that cannot use cabrucas. Large forest remnants are then fundamental to maintaining viable populations, especially for rare, large-bodied and area-demanding species. Research in other regions has shown that species that tolerate matrix habitat (such as cabrucas) are better able to survive in fragmented forest landscapes than species that do 
not, with the latter being particularly dependent on large, contiguous forest blocks (Laurance 1991, Gascon et al. 1999), hence the importance of an adequate system of protected areas and private forest reserves even in an overall "biodiversity-friendly" landscape like the cocoa region of southern Bahia.

Theoretical studies on forest fragmentation suggest that below 20 to $30 \%$ forest remnants in the landscape, species richness is negatively affected by fragmentation over and above forest loss per se (Fahrig 1998). While the lower overall diversity of the Ilhéus landscape (with $5 \%$ forest) compared to the Una landscape (with $50 \%$ forest) is in agreement with this theoretical conclusion, it is nevertheless striking that the forest-poor landscape of Ilhéus still has relatively diverse biological communities with presence of a large proportion of the native species of the region. There is no doubt that the combination of forest remnants with a matrix dominated by cabrucas and secondary forests are fundamental for the maintenance of these rich biological communities. Further studies are needed, however, to define limits in terms of percent cover and spatial configuration of forest remnants as well as the percent cover, configuration and characteristics of the cabrucas and other matrix habitat beyond which ecological processes and biodiversity would be substantially and irreversibly impaired.

While such questions await further study, some lessons clearly emerge from the existing evidence. In cocoa landscapes with still a high proportion of forest remnants (as in Una), these should be conserved to ensure the perpetuation of forest species, while cabrucas should be maintained in the matrix especially to provide connectivity and prevent the impoverishment of isolated, small remnants. In landscapes dominated by cabrucas with only little remaining forest cover (as in Ilhéus), on the other hand, the forest area should be increased to ensure the conservation of strict forest species, while the cabrucas should be maintained both for their essential role as habitat for many native species and to ensure a maximum of connectivity among the forest remnants. In this latter situation, adherence to current legislation requiring legal reserves (20\% of each property) and areas of permanent preservation (river margins and hill slopes) of native vegetation would lead to a substantial increase of total forest cover to about $30 \%$, in addition to the public protected areas (Faria 2007). The creation of private reserves (for which Brazilian law offers tax rebates) and expansion of public protected areas are further options to increase the total amount of forest habitat. Care should be taken to increase the proportion of natural forest in the landscape in a way that takes account of the beta diversity of natural species assemblages 
and is adequately stratified across underlying climatic, edaphic and topographic features. Special attention needs to be given to species with limited capacity to use cabrucas (Table 2). Action plans should be developed to maintain viable populations of these species in large remnants, possibly aided by dispersion corridors whose effectiveness should be monitored.

While all conversion of mature forest is illegal in the Atlantic Forest biome, the clearing of fallow land (e.g. for pasture or annual crops) should be done in such a way that forest remnants and cabrucas do not become isolated and that abrupt borders between forest and open areas are not unnecessarily created. Microclimatic effects and especially the increased prevalence of fire tend to progressively degrade especially small forest fragments with exposed borders (Gascon et al. 2000). Such effects can probably be reduced if forest edges are buffered by fallows, secondary forest or cabrucas, although the effectiveness of such spatial arrangements has not been established in Bahia.

\section{Cocoa management within the cabruca system}

The conservation of diversified and structurally complex shade canopies composed of native trees species in the cabrucas is important for the conservation of a large number of native tree species and as a structurally diverse habitat for many other organisms. Research is needed to establish new recommendations for shade tree densities, taking into account not only direct effects of shade on cocoa production, but also effects on production costs via suppression of weeds and biological pest control, as well as tree products (fruits, wood etc.). Incipient markets that specifically reward the conservation-friendly production of cocoa in cabruca systems may expand in the future. The internalization of environmental services such as carbon sequestration and contribution to the scenic beauty of the southern Bahian landscape with its high potential for tourism would create further incentives for maintaining traditional shade canopies. Guidelines need to be developed for managing the regeneration of the shade trees in cabrucas to prevent the gradual loss of late successional tree species and their replacement by (often exotic) pioneers. The management should ensure the persistence of endemic and endangered tree species (Figure 4), as well as species used by endemic fauna (Table 3), and should strengthen those features of cabrucas that are known to contribute to their habitat quality. Hollow trees, fallen logs, termite nests, trees and branches supporting bird's nests (especially of rare species) and other structures 
that are used by fauna should be conserved. Epiphytes and vines should not be removed from shade trees unless they interfere with the management of the area. When thinning or pruning the canopy, it may often be possible to maintain some connectivity in the canopy to facilitate the movement of species such as sloths and other arboreal fauna, especially where cabrucas abut on natural habitat. Education and capacity building programs that increase cocoa farmers' ability to identify tree species and their seedlings in the field are also needed (Eduardo Mariano Neto, pers. com. 2008). Pesticides should be used only locally if at all, and preference should be given to organic practices.

Hunting is illegal throughout the Atlantic Forest biome, although this law is generally not enforced. Hunting is widespread in the region and is likely to affect the density and distribution of most medium to large terrestrial mammals (Pardini 2001). Observations suggest that the farm owners' prohibition of hunting and their encouragement to keep small livestock as an alternative source of protein have potential to reduce hunting by farm workers (Santos 1999). Snakes are often killed for fear and because farm workers are often unable to distinguish poisonous from nonpoisonous species, hence the need for educational programs about the prevention of snake accidents, the harmlessness of most snake species, and the ecological importance of snakes in the control of their prey (e.g. rodents some of which can damage cocoa; Argôlo 2004). These recommendations are broadly valid for shaded cocoa (and other tree crop) systems elsewhere (Schroth et al. 2004).

\section{Conservation of endangered species}

Cabrucas should be considered priority landscape elements in action plans for the conservation of the pileated antwren (Herpsilochmus pileatus), the acrobat bird (Acrobatornis fonsecai), the golden-headed lion-tamarin (Leontopithecus chrysomelas), the maned three-toed sloth (Bradypus torquatus), the painted tree rat (Callistomys pictus) and the ant Dinoponera lucida. However, with the possible exception of the acrobat bird, sufficiently large forest remnants are essential for the conservation of these species, in addition to cabrucas. More research is needed to establish the exact role that cabrucas can play in the life cycles of these species and to identify management practices to increase their habitat value. Educational programs to increase the knowledge about these rare and endangered species in cabrucas among farm owners and workers should also be a priority. 


\subsection{Conclusions}

This review demonstrates that cabrucas are utilized by a substantial part of the fauna and flora native to southern Bahia. Given the high degree of forest loss and fragmentation in parts of the region, cabrucas have an important role to play in biodiversity conservation by providing alternative or additional habitat for many forest species, increasing connectivity between forest fragments, and reducing edge effects to which fragments are exposed.

Conservation strategies should consider the role of cabrucas at two spatial scales: the local management of the plantations, and the scale of the landscape within which cabrucas interact with other vegetation types. The studies reviewed here indicate that where a large part of the landscape is still covered by forest remnants, the landscape as a whole, and the cabrucas within it, are richer in species than where much of the original forest cover has been converted into cabrucas and other land-uses. Initiatives to conserve cabrucas as important habitat for many native species should thus always be seen in context with the conservation and restoration of natural forest habitat. Brazilian environmental legislation offers a legal framework to increase forest cover to $20-30 \%$ outside of protected areas, a value that, according to theoretical models, would be enough to support metapopulation dynamics in a fragmented landscape, especially where much of the remainder is covered by cabrucas that are sympathetically managed for conservation. Current scientific knowledge of the ecology of many species of the cocoa producing region of Bahia already allows us to identify management practices that help to maintain and increase the habitat value of cabrucas, although studies are needed on questions such as optimum shade tree densities and management practices to ensure the regeneration of canopy trees. Since cabrucas are production systems, any recommendation needs to take economic viability into account, and both costs and benefits of conservation friendly management should be monitored to inform a long-term plan of adaptive management. Long-term scientific studies are needed that relate biological diversity and the persistence of sensitive species to different combinations of cabrucas and natural forest in landscapes in order to determine threshold levels of deforestation and fragmentation beyond which biodiversity is significantly impaired. Further research should also be encouraged to relate variables such as the presence of food resources, shelter, vegetation structure and microclimate to the richness and composition of native species assemblages and especially the presence of sensitive forest species in cabrucas. It should also be remembered that no two cabrucas are the same. Cabrucas are derived from already highly heterogeneous forest through histories 
of establishment and subsequent plantation management that are, in combination, unique for each area. Thus, even when a list of general recommendations is set out to reconcile production and conservation, adaptation to local conditions will always be necessary, requiring ecologically educated and conscious farm owners and workers.

Finally, while this review focused on Bahia with its specific fauna, flora and culture of cocoa growing, many of our conclusions on the management of landscapes and cocoa production systems to reconcile biodiversity conservation with tree crop production are applicable to other geographical regions and add to an increasing pool of information on the biodiversity-friendly management of tropical land-use mosaics (Schroth et al. 2004, Schroth \& Harvey 2007).

\section{Acknowledgments}

The authors thank the participants of the First Symposium on the Cocoa Landscape and its Biodiversity in Southern Bahia held at the State University of Santa Cruz, Ilhéus, on 8-9 October 2007 who contributed information and ideas to this study. Tony Gardner, Bill Laurance, an anonymous referee and the editor made very useful comments on an earlier version. This paper benefited from grants from Seeds of Change to Conservation International, and from the European Union and the Brazilian Ministry of the Environment to IESB. CRC and JHCD acknowledge their research grants from FAPESP and CNPq, respectively.

\section{References}

ACCACIO, G. M. 2004. Comunidades de borboletas frugívoras em mosaico de ambientes florestais na região de Una, Bahia. PhD Thesis, Universidade de São Paulo, São Paulo, SP.

Alger, K., and M. CALDAS. 1994. The declining cocoa economy and the Atlantic forest of southern Bahia, Brazil: Conservation attitudes of cocoa planters. The Environmentalist 14: 107-119.

Alves, M. C. 1990. The role of cacao plantations in the conservation of the Atlantic forest of southern Bahia, Brazil. MSc Dissertation, University of Florida, Gainesville, FL. 
Alves, T. F. 2005. Distribuição geográfica, forófitos e espécies de bromélias epífitas nas matas e plantações de cacau da região de Una, Bahia. PhD Thesis, Universidade Estadual de Campinas, Campinas, SP.

Alvin, P. T. 1966. Problemas do sombreamento do cacaueiro. Cacau Atualidades 3: 3-5.

Alvin, P. T., and C. P. Pereira. 1970. Sombra e espaçamento nas plantações de cacau da Bahia. XXII Reunião Anual da Sociedade Brasileira para o Progresso da Ciência: Simpósio de pesquisas sobre o cacau, pp. 33-34.

Araújo, M., V. M. A. Fernandes, A. Marques, P. V. N. Souza, and A. Braga. 2007. Uso da terra e adequação ambiental da propriedade rural na região cacaueira da Bahia. I Simpósio sobre Paisagem Cacaueira e Biodiversidade no Sudeste da Bahia. Universidade Estadual de Santa Cruz, Ilhéus, BA.

ARGÔLO, A. J. S. 2004. As serpentes dos cacauais do sudeste da Bahia. Editus, Ilhéus, BA.

BARReto, R. M. F., and C. R. CASSANO. 2007. Uso do habitat por uma preguiça-de-coleira (Bradypus torquatus) em plantação de cacau (Theobroma cacao L.) sombreada por árvores nativas no sul da Bahia. I Simpósio sobre Paisagem Cacaueira e Biodiversidade no Sudeste da Bahia. Universidade Estadual de Santa Cruz, Ilhéus, BA.

Bencke, G. A., G. N. Maurício, P. R. Develey, and J. M. Goerck. 2006. Áreas importantes para a conservação das aves no Brasil: Parte I - estados do domínio da Mata Atlântica, inclui áreas de Cerrado, Caatinga e Pampas. SAVE-Brasil, São Paulo, SP.

BROWN JR., K. S. 1982. Paleoecology and regional patterns of evolution in Neotropical forest butterflies. In: G. T. Prance (Ed.). Biological Diversification in the Tropics, Columbia University Press, New York, NY, pp. 255-308.

CASSANO, C. R. 2006. Ecologia e conservação da preguiça-de-coleira (Bradypus torquatus, Illiger, 1812) no sul da Bahia. MSc Dissertation, Universidade Estadual de Santa Cruz, Ilhéus, BA.

CASSANO, C. R. 2007. Registros fotográficos de mico-leão-de-cara-dourada (Leontopithecus chrysomelas) em plantações de cacau no município de Una, Bahia. I Simpósio sobre Paisagem Cacaueira e Biodiversidade no Sudeste da Bahia. Universidade Estadual de Santa Cruz, Ilhéus, BA. 
Cassano, C. R., and R. T. Moura. 2003. Mamíferos em sistemas produtivos de cultura permanente no entorno da Reserva Biológica de Una, Una, BA. II Congresso Brasileiro de Mastozoologia. PUC, Belo Horizonte, MG.

CATENACCI, L. S. 2008. Ecologia alimentar do mico-leão-da-cara-dourada (Leontopithecus chrysomelas, Callitrichidae, Primates) em áreas degradadas da Mata Atlântica do sul da Bahia. MSc Dissertation, Universidade Estadual de Santa Cruz, Ilhéus, BA.

Correia, T. L., C. R. Cassano, and R. M. F. Barreto. 2006. Comportamento de filhote desmamado e fêmea adulta de preguiça-de-coleira (Bradypus torquatus), Bahia, Brasil. VII Congresso Internacional sobre Manejo de Fauna Silvestre na Amazônia e América Latina. Ilhéus, BA.

Delabie, J. H. C. 1990. The ant problems of cocoa farms in Brazil. In: R. K. V. Meer, K. Jaffe and A. Cedeno (Eds.). Applied Myrmecology: A World Perspective. Boulder, pp. 555-569.

Delabie, J. H. C. 2003. Comunidades de formigas das árvores nas formações florestais da América do Sul, com ênfase no sudeste da Bahia. XVI Simpósio de Mirmecologia. Florianopolis, SC.

Delabie, J. H. C., B. Jahyny, I. C. do Nascimento, C. S. F. Mariano, S. Lacau, S. CAMPIOLO, S. M. PhilPOTT, and M. LEPONCE. 2007. Contribution of cocoa plantations to the conservation of native ants (Insecta: Hymenoptera: Formicidae) with a special emphasis on the Atlantic forest fauna of southern Bahia, Brazil. Biodiversity Conserv. 16: $2359-2384$.

Delabie, J. H. C., and C. S. F. MARiano. 2001. Papel das formigas (Insecta: Hymenoptera: Formicidae) no controle biológico natural das pragas do cacaueiro na Bahia: síntese e limitações. XIII International Cocoa Research Conference. Sabah, Malásia.

Delabie, J. H. C., C. S. F. Mariano, and I. C. Nascimento. 1998. As formigas do Município de Ilhéus (Insecta: Hymenoptera: Formicidae). Especiaria 1: 133-152.

Delabie, J. H. C., I. C. Nascimento, and C. S. F. Mariano. 1999. Importance de l'agriculture cacaoyère pour le maintien de la biodiversité: étude comparée de la myrmécofaune de différents milieux du sud-est de Bahia, Brésil (Hymenoptera; Formicidae). XII International Cocoa Research Conference. Lagos, Nigeria. 
DIXO, M. 2001. Efeito da fragmentação da floresta sobre a comunidade de sapos e lagartos de serapilheira no Sul da Bahia. MSc Dissertion, Universidade de São Paulo, São Paulo, SP.

FAHRIG, L. 1998. When does fragmentation of breeding habitat affect population survival? Ecological Modelling 105: 273-292.

FARIA, A. 2002. Comunidade de morcegos em uma paisagem fragmentada da Mata Atlântica do sul da Bahia, Brasil. PhD Thesis, Universidade Estadual de Campinas, Campinas, SP.

FARIA, A. 2007. Cobertura de remanescentes florestais e plantações de cacau na paisagem da região cacaueira do sul da Bahia. I Simpósio sobre Paisagem Cacaueira e Biodiversidade no Sudeste da Bahia. Universidade Estadual de Santa Cruz, Ilhéus, BA.

FARIA, D. 2006. Phyllostomids bats of a fragmented landscape in north-eastern Atlantic forest, Brazil. J. Trop. Ecol. 22: 531-542.

FARIA, D., and J. BAUMGARTEN. 2007. Shade cacao plantations (Theobroma cacao) and bat conservation in southern Bahia, Brazil. Biodiversity Conserv. 16: 291-312.

Faria, D., R. R. Laps, J. Baumgarten, and M. Cetra. 2006. Bat and bird assemblages from forests and shade cacao plantations in two contrasting landscapes in the Atlantic forest of southern Bahia, Brazil. Biodiversity Conserv. 15: 587-612.

Faria, D., M. L. B. Paciencia, M. DiXo, R. R. Laps, and J. Baumgarten. 2007. Ferns, frogs, lizards, birds and bats in forest fragments and shade cacao plantations in two contrasting landscapes in the Atlantic forest, Brazil. Biodiversity Conserv. 16: 23352357.

FARIAS, S., and D. FARIA. 2007. Artibeus obscuros e as cabrucas do sudeste da Bahia: dados preliminares. I Simpósio sobre Paisagem Cacaueira e Biodiversidade no Sudeste da Bahia. Universidade Estadual de Santa Cruz, Ilhéus, BA

Fenton, M. B., L. Acharya, D. Audet, M. B. C. Hickey, C. Merriman, M. K. Obrist, D. M. SYME, and B. ADKINS. 1992. Phyllostomid bats (Chiroptera - Phyllostomidae) as indicators of habitat disruption in the Neotropics. Biotropica 24: 440-446.

FranKS, N. R. 1989. Army ants - A collective intelligence. American Scientist 77: 138145. 
Gascon, C., T. E. Lovejoy, R. O. Bierregaard, J. R. Malcolm, P. C. Stouffer, H. L. Vasconcelos, W. F. Laurance, B. Zimmerman, M. Tocher, and S. Borges. 1999. Matrix habitat and species richness in tropical forest remnants. Biol. Conserv. 91: 223229.

Gascon, C., G. B. Williamson, and G. A. B. DA Fonseca. 2000. Ecology - Receding forest edges and vanishing reserves. Science 288: 1356-1358.

Giné, G. A. F., Y. Le Pendu, J. M. B. Duarte, S. Farias, and D. Faria. 2006. Uso do espaço pelo ouriço-preto (Chaetomys subspinosus, Olfers 1818) na região cacaueira do sul da Bahia. VII Congresso Internacional sobre Manejo de Fauna Silvestre na Amazônia e América Latina. Ilhéus, BA.

Harvey, C. A., J. Gonzalez, and E. Somarriba. 2006. Dung beetle and terrestrial mammal diversity in forests, indigenous agroforestry systems and plantain monocultures in Talamanca, Costa Rica. Biodiversity Conserv. 15: 555-585.

Harvey, C. A., and J. A. G. Villalobos. 2007. Agroforestry systems conserve speciesrich but modified assemblages of tropical birds and bats. Biodiversity Conserv. 16: 2257-2292.

Henry, M., and E. K. V. KalKo. 2007. Foraging strategy and breeding constraints of Rhinophylla pumilio (Phyllostomidae) in the Amazon lowlands. J. Mammal. 88: 8193.

IUCN. 2008. IUCN Red List of Threatened Species. www.redlist.org, accessed March 18, 2008.

IZAC, A. M. N., and P. A. SANCHEZ. 2001. Towards a natural resource management paradigm for international agriculture: The example of agroforestry research. Agricultural Systems 69: 5-25.

Johns, N. D. 1999. Conservation in Brazil's chocolate forest: The unlikely persistence of the traditional cocoa agroecosystem. Environ. Manage. 23: 31-47.

LaCau, S., C. Villemant, and J. H. C. Delabie. 2004. Typhlomyrmex meire, a remarkable new species endemic to southern Bahia, Brazil (Formicidae: Ectatomminae). Zootaxa 678: 1-23.

LANDAU, E. C. 2003. Padrões de ocupação espacial da paisagem na Mata Atlântica do sudeste da Bahia, Brasil. In: P. I. Prado, E. C. Landau, R. T. Moura, L. P. Pinto, K. 
Alger and G. A. B. Fonseca (Eds.). Corredor de Biodiversidade da Mata Atlântica do Sul da Bahia. IESB/CI/CABS/UFMG/UNICAMP, Ilhéus, BA, CD-Room.

LAURANCE, W. F. 1991. Ecological correlates of extinction proneness in Australian tropical rain-forest mammals. Conserv. Biol. 5: 79-89.

Lobão, D. E. V. P. 2007. Agroecossistema cacaueiro da Bahia: Cacau cabruca e fragmentos florestais na conservação de espécies arbóreas. PhD Thesis, Universidade Estadual Paulista, Jaboticabal, SP.

Majer, J. D., J. H. C. Delabie, and M. R. B. Smith. 1994. Arboreal ant community patterns in Brazilian Cocoa Farms. Biotropica 26: 73-83.

MARques, J. R. B., and W. R. MonTeiro. 2006. Adoção do sistema agroflorestal cacau x seringa - Melhoria de condições de cultivo e agregação de valores. $28^{\mathrm{a}}$ Semana do Fazendeiro. CEPLAC/CENEX/EMARC, Itabuna, BA, pp. 9-14.

MARTINI, A. M. Z. 2007. Florestas não são compostas apenas de árvores: A importância do componente não-arbóreo nas florestas do sul da Bahia. I Simpósio sobre Paisagem Cacaueira e Biodiversidade no Sudeste da Bahia. Universidade Estadual de Santa Cruz, Ilhéus, BA

Martini, A. M. Z., P. Fiaschi, A. M. Amorim, and J. L. DA PAiXAO. 2007. A hot-point within a hot-spot: A high diversity site in Brazil's Atlantic Forest. Biodiversity Conserv. 16: 3111-3128.

Medellin, R. A., M. EquinuA, and M. A. Amin. 2000. Bat diversity and abundance as indicators of disturbance in neotropical rainforests. Conserv. Biol. 14: 1666-1675.

Mota, L., E. MARIANO-Neto, and D. FARIA. 2007. Aspectos da estrutura e diversidade da flora arbórea na região cacaueira do sul da Bahia. I Simpósio sobre Paisagem Cacaueira e Biodiversidade no Sudeste da Bahia. Universidade Estadual de Santa Cruz, Ilhéus, BA

MourA, R. T. 1999. Análise comparativa da estrutura de comunidades de pequenos mamíferos em remanescente de Mata Atlântica e em plantio de cacau em sistema de cabruca no sul da Bahia. MSc Dissertation, Universidade Federal de Minas Gerais, Belo Horizonte, MG. 
MOURA, R. T. 2005. Observações preliminares sobre ocorrência, distribuição, biologia e ecologia do rato-do-cacau (Callistomys pictus), na Mata Atlântica, sul da Bahia. III Congresso Brasileiro de Mastozoologia. Aracruz, ES

MourA, R. T. 2008. Callistomys pictus. In: A. B. M. Machado, G. M. Drummond and A. P. Paglia (Eds.). Livro Vermelho da Fauna Brasileira Ameaçada de Extinção. Ministry of the Environment, Brasília, DF, pp. 823-825.

NAscimento, W., T. A. FontourA, and B. E. RABOY. 2007. Interação entre mico-leão-dacara-dourada e bromélias em uma cabruca no sul da Bahia, Brasil. I Simpósio sobre Paisagem Cacaueira e Biodiversidade no Sudeste da Bahia. Universidade Estadual de Santa Cruz, Ilhéus, BA

Neves, L. G., N. Cardoso, G. R. Santos, and B. E. Raboy. 2007. Ocorrência de primatas em diversos tipos de cobertura florestal no sul da Bahia, com ênfase na cabruca. I Simpósio sobre Paisagem Cacaueira e Biodiversidade no Sudeste da Bahia. Universidade Estadual de Santa Cruz, Ilhéus, BA

OliveirA, L. C., J. M. Dietz, and B. E. RABOy. 2007. Árvores importantes para o micoleão-de-cara-dourada (Leontopithecus chrysomelas): Implicações para o manejo da agrofloresta cabruca no sudeste da Bahia. I Simpósio sobre Paisagem Cacaueira e Biodiversidade no Sudeste da Bahia. Universidade Estadual de Santa Cruz, Ilhéus, BA

Ortiz, J. V., D. Faria, J. Baumgarten, and R. Pardini. 2002. Faunal responses to different habitats and landscape configurations in southeastern Bahia: Implications for ecological corridors planning. III Congresso Brasileiro de Unidades de Consevação. Fortaleza, CE, pp. 629-638.

Pacheco, J. F., B. M. Whitney, and L. P. Gonzaga. 1996. New genus and species of furnariid (Aves: Furnariidae) from the cocoa-growing region of southeastern Bahia, Brazil. Wilson Bulletin 108: 397-433.

Paciencia, M. L. B., and J. Prado. 2004. Efeitos de borda sobre a comunidade de pteridófitas na Mata Atlântica da região de Una, sul da Bahia, Brasil. Revista Brasileira de Botânica 27: 641-653.

Paciencia, M. L. B., and J. Prado. 2005a. Distribuição espacial da assembléia de pteridófitas em uma paisagem fragmentada de Mata Atlântica no sul da Bahia, Brasil. Hoehnea 32: 103-117. 
PACIENCIA, M. L. B., and J. PrAdo. 2005b. Effects of forest fragmentation on pteridophyte diversity in tropical rain forest in Brazil. Plant Ecology 180: 87-104.

PARDINI, R. 2001. Pequenos mamíferos e a fragmentação da Mata Atlântica de Una, Sul da Bahia - Processos e conservação. PhD Thesis, Universidade de São Paulo, São Paulo, SP.

PARDINI, R. 2004. Effects of forest fragmentation on small mammals in an Atlantic forest landscape. Biodiversity Conserv. 13: 2567-2586.

Pinto, L. P., I. R. LAmas, M. A. L. SABAtO, and L. I. TAVARES. 1993. Inventário faunístico e conservação da Mata Atlântica do sul da Bahia. Fundação Biodiversitas, Belo Horizonte, MG.

Prado, J. 2000. A new species of Adianturn (Pteridaceae) from Bahia, Brazil. Brittonia 50: $210-212$.

Raboy, B. E., M. C. Christman, and J. M. Dietz. 2004. The use of degraded and shade cocoa forests by endangered golden-headed lion-tamarins Leontopithecus chrysomelas. Oryx 38: 75-83.

Rice, R. A., and R. GreEnBerg. 2000. Cacao cultivation and the conservation of biological diversity. Ambio 29: 167-173.

Rolim, S. G., and A. G. Chiarello. 2004. Slow death of Atlantic forest trees in cocoa agroforestry in southeastern Brazil. Biodiversity Conserv. 13: 2679-2694.

RuF, F., and G. Schroth. 2004. Chocolate forests and monocultures: A historical review of cocoa growing and its conflicting role in tropical deforestation and forest conservation. In: Schroth, G., G. A. B. Fonseca, C. A. Harvey, C. Gascon, H. L. Vasconcelos, and A. M. N. Izac. (Eds.). Agroforestry and Biodiversity Conservation in Tropical Landscapes. Island Press, Washington, DC, pp. 135-150.

SAMBUICHI, R. H. R. 2002. Fitossociologia e diversidade de espécies arbóreas em cabruca (Mata Atlântica raleada sobre plantação de cacau) na região sul da Bahia, Brasil. Acta Botanica Brasilica 16: 89-101.

SAMBUICHI, R. H. R. 2006. Estrutura e dinâmica do componente arbóreo em área de cabruca na região cacaueira do sul da Bahia, Brasil. Acta Botanica Brasilica 20: 943954. 
SAMBUiCHI, R. H. R., and M. HARIDASAN. 2007. Recovery of species richness and conservation of native Atlantic forest trees in the cacao plantations of southern Bahia in Brazil. Biodiversity Conserv. 16: 3681-3701.

SAnTos, G. R. 1999. Caracterização da caça na região do entorno da Reserva Biológica de Una-BA. Projeto Remanescentes de Florestas na Região de Una, BA, RestaUna/PROBIO, Ilhéus, BA.

Schroth, G., G. A. B. Fonseca, C. A. Harvey, C. Gascon, H. L. Vasconcelos, and A. M. N. IZAC. 2004. Agroforestry and Biodiversity Conservation in Tropical Landscapes. Island Press, Washington, DC.

Schroth, G., and C. A. Harvey. 2007. Biodiversity conservation in cocoa production landscapes: an overview. Biodiversity Conserv. 16: 2237-2244.

Sperber, C. F., K. Nakayama, M. J. Valverde, and F. D. Neves. 2004. Tree species richness and density affect parasitoid diversity in cacao agroforestry. Basic and Applied Ecology 5: 241-251.

Thomas, W. W. 2003. Lista preliminaria das angiospermas localmente endêmicas do sul da Bahia e norte do Espírito Santo, Brasil. In: P. I. Prado, E. C. Landau, R. T. Moura, L. P. Pinto, K. Alger and G. A. B. Fonseca (Eds.). Corredor de Biodiversidade da Mata Atlântica do Sul da Bahia. IESB/CI/CABS/UFMG/UNICAMP, Ilhéus, BA, CDRoom.

Thomas, W. W., A. de Carvalho, A. M. A. Amorim, J. Garrison, and A. L. Arbelaez. 1998. Plant endemism in two forests in southern Bahia, Brazil. Biodiversity Conserv. 7: 311-322.

VinHA, S. G., and L. A. M. Silva. 1982. Árvores aproveitadas como sombreadoras de cacaueiros no sul da Bahia e norte do Espírito Santo. Comissão Executiva do Plano da Lavoura Cacaueira, Ilhéus, BA. 
Table 1: Number of species and total recordings of small mammals, bats, birds, litter frogs and lizards, frugivorous butterflies, ferns, and bromeliads in the interior of large forest remnants and cabrucas in the county of Una, southern Bahia, Brazil.

\begin{tabular}{|c|c|c|c|c|c|}
\hline Biological group & $\begin{array}{l}\text { Forest } \\
\text { interior }\end{array}$ & Cabruca & $\begin{array}{l}\text { Species common to } \\
\text { both habitats }\end{array}$ & Principal changes in communities & Source \\
\hline $\begin{array}{l}\text { Small mammals } \\
\text { \# recordings } \\
\text { \# species }\end{array}$ & $\begin{array}{c}195 \\
11\end{array}$ & $\begin{array}{c}299 \\
13\end{array}$ & * & Change in the relative dominance among species & Pardini 2004 \\
\hline $\begin{array}{l}\text { Bats } \\
\text { \# recordings } \\
\text { \# species }\end{array}$ & $\begin{array}{c}278 \\
18\end{array}$ & $\begin{array}{c}1314 \\
39\end{array}$ & 16 & $\begin{array}{l}\text { Greater richness and abundance in cabrucas (with possible influence of } \\
\text { the sampling method in the more open environment); change in the } \\
\text { relative dominance between the two most common species }\end{array}$ & $\begin{array}{l}\text { Faria 2002; } \\
\text { Faria et al. } 2006\end{array}$ \\
\hline $\begin{array}{l}\text { Birds } \\
\text { \# recordings } \\
\text { \# species }\end{array}$ & $\begin{array}{c}1610 \\
121\end{array}$ & $\begin{array}{c}2459 \\
158\end{array}$ & 94 & $\begin{array}{l}\text { Greater richness in cabrucas as effect of the invasion of species from } \\
\text { more open environments; change in the relative abundance among } \\
\text { species }\end{array}$ & Laps 2006 \\
\hline $\begin{array}{l}\text { Litter frogs } \\
\text { \# recordings } \\
\text { \# species }\end{array}$ & $\begin{array}{c}763 \\
12\end{array}$ & $\begin{array}{c}217 \\
12\end{array}$ & 11 & No significant change in richness, abundance or species composition & Dixo 2001 \\
\hline $\begin{array}{l}\text { Litter lizards } \\
\text { \# recordings } \\
\text { \# species }\end{array}$ & $\begin{array}{l}53 \\
10\end{array}$ & $\begin{array}{c}148 \\
9\end{array}$ & 9 & Change in the relative dominance among species & Dixo 2001 \\
\hline $\begin{array}{l}\text { Frugivorous butte } \\
\text { \# recordings } \\
\text { \# species }\end{array}$ & $\begin{array}{c}233 \\
43\end{array}$ & $\begin{array}{c}636 \\
51\end{array}$ & 30 & Change in the relative dominance among species & Accacio 2004 \\
\hline $\begin{array}{l}\text { Ferns } \\
\text { \# recordings } \\
\text { \# species }\end{array}$ & $\begin{array}{c}1479 \\
32\end{array}$ & $\begin{array}{c}1019 \\
26\end{array}$ & 7 & Different species composition & $\begin{array}{l}\text { Paciencia \& } \\
\text { Prado } 2005\end{array}$ \\
\hline $\begin{array}{l}\text { Bromeliads } \\
\text { \# recordings } \\
\text { \# species } * *\end{array}$ & $\begin{array}{l}711 \\
25\end{array}$ & $\begin{array}{c}264 \\
18\end{array}$ & 13 & Different species composition & Alves 2005 \\
\hline
\end{tabular}


Table 2: Species known to rarely occur in cabrucas

\begin{tabular}{|c|c|c|c|}
\hline Taxon & Common name & Restrictions to use of cabrucas & Source \\
\hline $\begin{array}{l}\text { Mammals } \\
\text { Cebus xanthosternos } \\
\text { Callicebus melanochir } \\
\text { Mazama sp } \\
\text { Pecari tajacu } \\
\text { Chaetomys subespinosus }\end{array}$ & $\begin{array}{l}\text { yellow-breasted capuchin monkey } \\
\text { coastal black-handed titi } \\
\text { deer } \\
\text { wild pig } \\
\text { bristle-spined porcupine }\end{array}$ & Low probability to use cabrucas & $\begin{array}{l}\text { Alves 1990; } \\
\text { Giné et al. } 2006\end{array}$ \\
\hline $\begin{array}{l}\text { Callistomys pictus } \\
\text { Didelphis marsupialis }\end{array}$ & $\begin{array}{l}\text { painted tree rat } \\
\text { common oppossum }\end{array}$ & $\begin{array}{l}\text { Relatively tolerant to the habitat modifications occurring } \\
\text { when forest is converted into cabruca, but abundance in } \\
\text { these plantations probably reduced by hunting }\end{array}$ & $\begin{array}{l}\text { Moura 2005; } \\
\text { Moura 2008; } \\
\text { Alves 1990 } \\
\end{array}$ \\
\hline $\begin{array}{l}\text { Bradypus torquatus } \\
\text { Leontopithecus } \\
\text { chrysomelas }\end{array}$ & $\begin{array}{l}\text { maned three-toed sloth } \\
\text { golden-headed lion-tamarin }\end{array}$ & $\begin{array}{l}\text { Use of cabrucas dependent on the occurrence of plant } \\
\text { species that make up its diet, density of shade trees and } \\
\text { proximity of forest remnants }\end{array}$ & $\begin{array}{l}\text { Cassano 2006; } \\
\text { Raboy et al. 2004; } \\
\text { Alves } 1990\end{array}$ \\
\hline $\begin{array}{l}\text { Oryzomys laticeps } \\
\text { Marmosops incanus } \\
\text { Monodelphis americana }\end{array}$ & $\begin{array}{l}\text { forest rat } \\
\text { three-striped short-tailed oppossum }\end{array}$ & Low probability of using cabrucas & Pardini 2004 \\
\hline Rhinophylla pumilio & bat & $\begin{array}{l}\text { Low probability of using cabrucas when they are } \\
\text { inserted in a landscape with little native forest }\end{array}$ & $\begin{array}{l}\text { Faria et al. 2006; } \\
\text { Faria \& Baumgarten } 2007\end{array}$ \\
\hline $\begin{array}{l}\text { Birds } \\
\text { Lipaugus vociferans }\end{array}$ & & Low probability of using cabrucas & Faria et al. 2006 \\
\hline $\begin{array}{l}\text { Drymorphyla squamata } \\
\text { Herpsilochmus pileatus } \\
\text { Pyriglena leucoptera } \\
\text { Rhytipterna simplex } \\
\text { Formicarius colma }\end{array}$ & "chorozinho-da-Bahia" & $\begin{array}{l}\text { Low probability of using cabrucas when they are } \\
\text { inserted in a landscape with little native forest }\end{array}$ & Faria et al. 2006 \\
\hline $\begin{array}{l}\text { Formicaridae and Pipridae } \\
\text { Cracidae and Tinamidae }\end{array}$ & $\begin{array}{l}\text { understory birds } \\
\text { terrestrial birds }\end{array}$ & Low probability of using cabrucas & Alves 1990 \\
\hline
\end{tabular}


Table 2 (cont.)

\begin{tabular}{|c|c|c|c|}
\hline Taxon & Common name & Restrictions to use of cabrucas & Source \\
\hline $\begin{array}{l}\text { Reptiles and Amphibians } \\
\text { Enyalus catenatus pictus } \\
\text { Adelophrine pachydactyla } \\
\text { Cycloramphus migueli } \\
\text { Leptodactylus spixi } \\
\text { Chiasmocleis gnoma }\end{array}$ & $\begin{array}{l}\text { lizard } \\
\text { litter frog } \\
\text { litter frog } \\
\text { litter frog } \\
\text { littler frog }\end{array}$ & Low probability of using cabrucas & $\begin{array}{l}\text { Dixo 2001; } \\
\text { Faria et al. } 2007\end{array}$ \\
\hline $\begin{array}{l}\text { Bothrops bilineatus } \\
\text { Lachesis muta }\end{array}$ & $\begin{array}{l}\text { forest pitviper } \\
\text { South American bushmaster }\end{array}$ & Low probability of using cabrucas & Argolo 2005 \\
\hline Subfamily Morfidae & fruit eating butterflies & Low probability of using cabrucas & Accacio 2004 \\
\hline $\begin{array}{l}\text { Epiphytic bromeliads } \\
\text { Aechmea mollis } \\
\text { A. turbinocalyx } \\
\text { Areococcus paviflorus } \\
\text { Lymania globosa } \\
\text { L. azurea } \\
\text { L. smithii } \\
\text { Nidularium amorimii } \\
\text { Vriesea drepanocarpa } \\
\text { V. duvaliana }\end{array}$ & understory bromeliads & Low probability of occurring in cabrucas & Alves 2005 \\
\hline $\begin{array}{l}\text { Aechmea conifera } \\
\text { A. leonard-kentiana } \\
\text { Aechmea sp. }\end{array}$ & canopy bromeliads & Low probability of occurring in cabrucas & Alves 2005 \\
\hline
\end{tabular}


Table 3: Tree species recorded in cabrucas (Sambuichi and Haridasan 2007) that are part of the diet of golden-headed lion-tamarins - GHLT (Raboy et al. 2004) and maned threetoed sloths (Cassano 2006, Correia et al. 2006) or listed as endemic (Thomas 2003) or endangered species (IUCN 2008).

\begin{tabular}{|c|c|c|c|c|c|}
\hline Family / Species & Common name & GHLT diet & Sloth diet & Endemic & IUCN $^{1}$ \\
\hline \multicolumn{6}{|l|}{ Anacardiaceae } \\
\hline Tapirira guianensis & pau-pombo & $\mathrm{x}$ & $\mathrm{x}$ & & \\
\hline \multicolumn{6}{|l|}{ Annonaceae } \\
\hline Rollinia bahiensis & & & & $\mathrm{x}$ & VU \\
\hline \multicolumn{6}{|l|}{ Apocynaceae } \\
\hline Lacmellea aculeata & & $\mathrm{x}$ & & & \\
\hline Rauvolfia bahiensis & & & & $\mathrm{x}$ & \\
\hline \multicolumn{6}{|l|}{ Bignoniaceae } \\
\hline Tabebuia elliptica & & $\mathrm{x}$ & & & \\
\hline \multicolumn{6}{|l|}{ Bombacaceae } \\
\hline Eriotheca sp. & imbiruçú & & E. globosa & & \\
\hline \multicolumn{6}{|l|}{ Caesalpiniaceae } \\
\hline Arapatiella psilophylla & & & & $\mathrm{x}$ & VU \\
\hline Caesalpinia echinata & pau-brasil & & & & EN \\
\hline Dialium guianense & jitaí-preto & $\mathrm{x}$ & $\mathrm{x}$ & & \\
\hline Hymenaea oblongifolia & & & & $\mathrm{x}$ & \\
\hline Macrolobium latifolium & & $\mathrm{x}$ & $\mathrm{x}$ & & \\
\hline Senna multijuga & canafístula/cobi & & $\mathrm{x}$ & & \\
\hline \multicolumn{6}{|l|}{ Cecropiaceae } \\
\hline Cecropia spp. & embaúba & & Cecropia & & \\
\hline
\end{tabular}

\section{Clusiaceae}

Symphonia globulifera

guanandí

$\mathrm{X}$

\section{Ebenaceae}

Diospyros melinonii

$\mathrm{x}$

\section{Euphorbiaceae}

Mabea piriri

\section{Fabaceae}

Dalbergia nigra

jacarandá

VU

\section{Lauraceae}

Aniba intermedia

VU

\section{Lecythidaceae}

Cariniana legalis

jequitiba-cipó

Lecythis lurida

inhaíba

$\mathrm{LR} / \mathrm{cd}$

\section{Malpighiaceae}

Byrsonima laevigata 
Table 3 (cont.)

\begin{tabular}{|c|c|c|c|c|c|}
\hline Family / Species & Common name & GHLT diet & Sloth diet & Endemic & $\mathbf{I U C N}^{2}$ \\
\hline \multicolumn{6}{|l|}{ Meliaceae } \\
\hline Cedrela odorata & cedro roxo & & & & VU \\
\hline \multicolumn{6}{|l|}{ Mimosaceae } \\
\hline Parkia pendula & jueirana & $\mathrm{x}$ & & & \\
\hline \multicolumn{6}{|l|}{ Monimiaceae } \\
\hline Bracteanthus atlanticus & & & & $\mathrm{x}$ & \\
\hline \multicolumn{6}{|l|}{ Moraceae } \\
\hline Artocarpus heterophyllus & jaqueira & $\mathrm{x}$ & & & \\
\hline Brosimum guianense & & & $\mathrm{x}$ & & \\
\hline Brosimum rubescens & condurú & $\mathrm{x}$ & $\mathrm{x}$ & & \\
\hline Ficus pulchella & figueira & & & & VU \\
\hline Ficus spp. & figueira & $\mathrm{x}$ & $\mathrm{x}$ & & \\
\hline Sorocea guilleminiana & & & & & VU \\
\hline \multicolumn{6}{|l|}{ Myristicaceae } \\
\hline Virola gardneri & bicuíba & & $\mathrm{x}$ & & \\
\hline \multicolumn{6}{|l|}{ Myrtaceae } \\
\hline Eugenia flamingensis & & & & $\mathrm{x}$ & \\
\hline Eugenia sp. & & $\mathrm{x}$ & & & \\
\hline Psidium sp. & & P. guajava & & & \\
\hline \multicolumn{6}{|l|}{ Polygonaceae } \\
\hline Coccoloba alnifolia & & Coccoloba & & & \\
\hline \multicolumn{6}{|l|}{ Rubiaceae } \\
\hline Guettarda platyphylla & & $\mathrm{x}$ & & & \\
\hline
\end{tabular}

\section{Santalaceae}

Acanthosyris paulo-alvinii

$\mathrm{X}$

\begin{tabular}{|c|c|c|c|}
\hline \multicolumn{4}{|l|}{ Sapotaceae } \\
\hline Chrysophyllum splendens & & & VU \\
\hline Manilkara elata & maçaranduba & Manilkara & EN \\
\hline Micropholis compta & & & VU \\
\hline Micropholis & & & $\mathrm{LR} / \mathrm{cd}$ \\
\hline Micropholis sp. & & Micropholis & \\
\hline Pouteria beaurepairei & & & $\mathrm{LR} / \mathrm{cd}$ \\
\hline Pouteria grandiflora & & & $\mathrm{LR} / \mathrm{nt}$ \\
\hline Pouteria bangii & & $\mathrm{x}$ & \\
\hline \multicolumn{4}{|l|}{ Simaroubaceae } \\
\hline Simarouba amara & arubá & $\mathrm{x}$ & \\
\hline
\end{tabular}




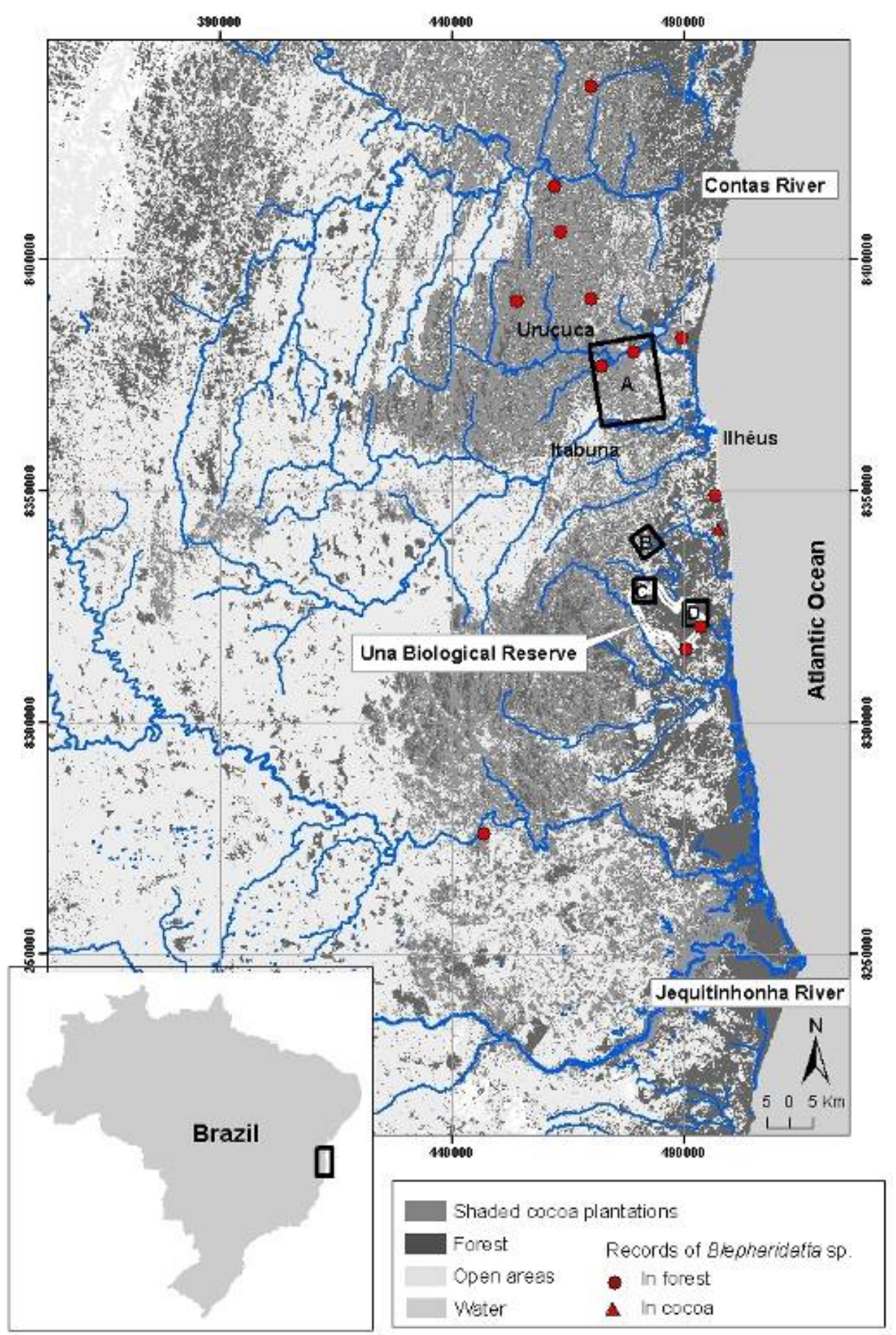

Figure 1: The cocoa region of southern Bahia, Brazil, delimited by the Rio Contas and Rio Jequitinhonha, with the location of two landscapes with low forest cover (Ilhéus - A) and high forest cover (Una - B, C and D) where the biodiversity of cabrucas and forests was studied. The symbols refer to sampling locations of the endemic ant species, Blepharidatta sp. n (modified after Landau et al. 2003). 
(A)

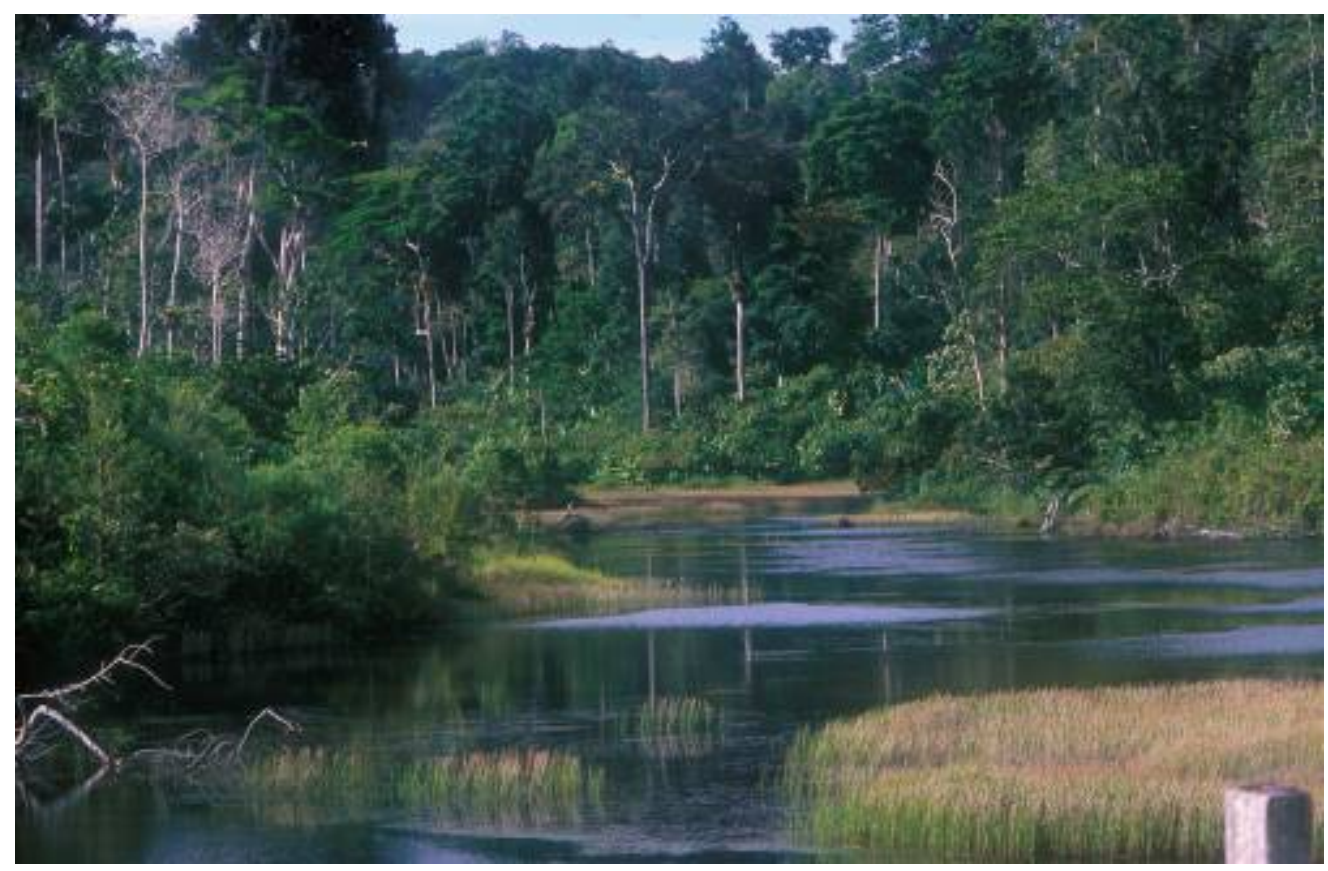

(B)

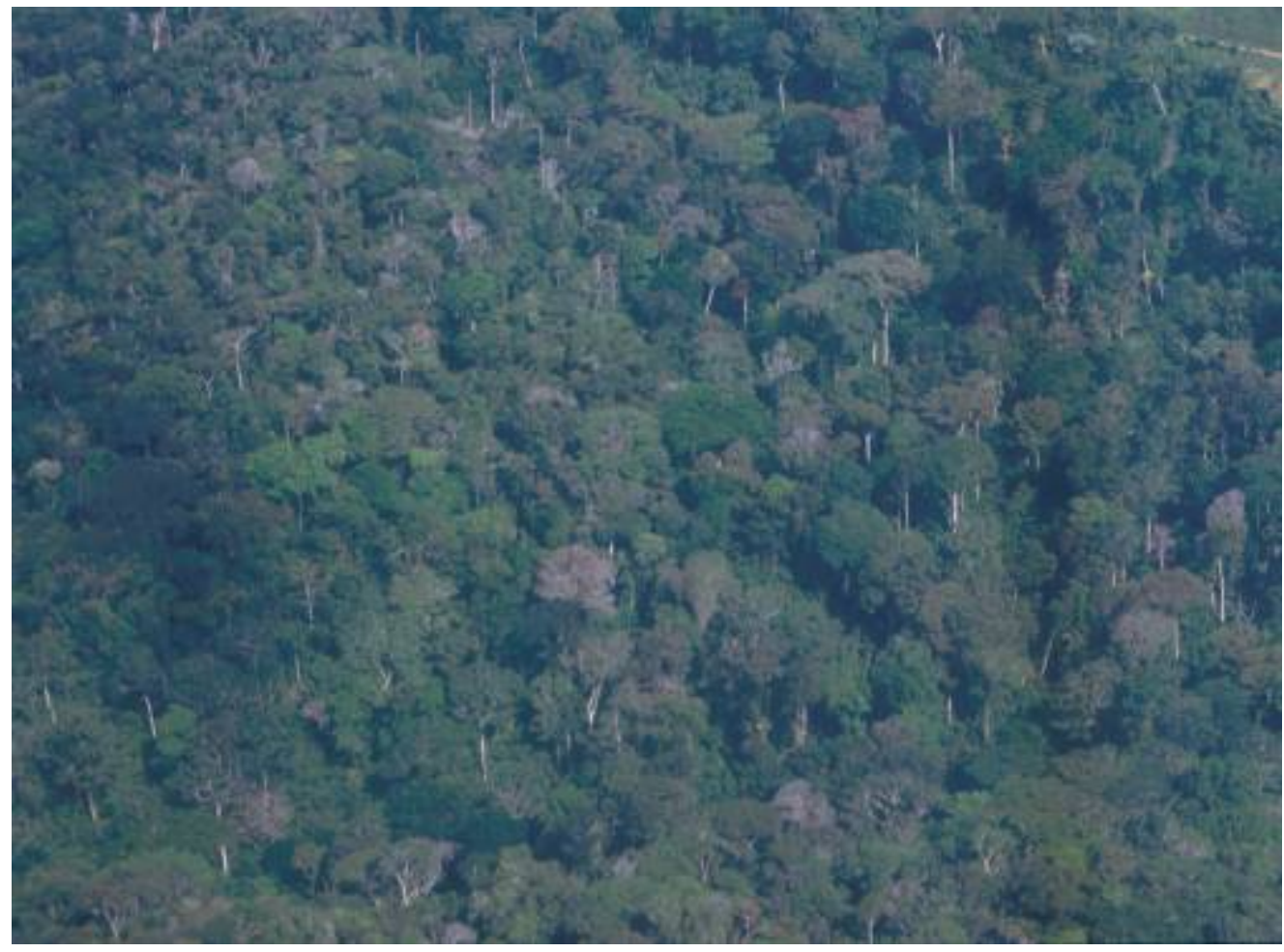

Figure 2: Traditional cabrucas of southern Bahia, Brazil, retain much of the original forest structure. A) Cabruca in the county of Una; B) Aerial view of a cabruca in the same region (Photos by G. Accacio, with permission). 


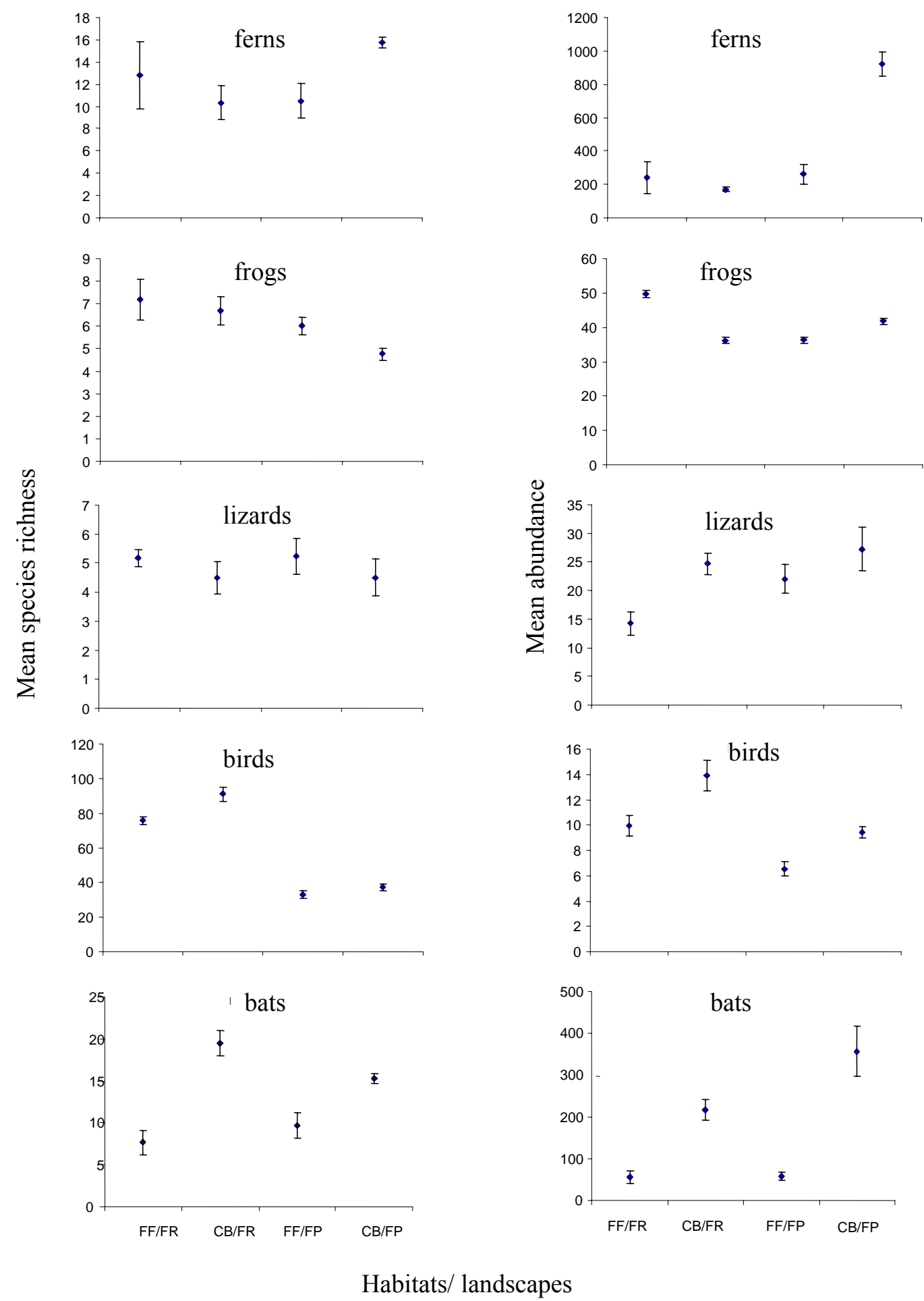

Figure 3: Richness and abundance of different biological groups in forest fragments (FF) and cabrucas (CB) in a forest-rich (Una - FR) and a forest-poor (Ilhéus - FP) landscape in southern Bahia, Brazil (from Faria et al. 2007, modified). 


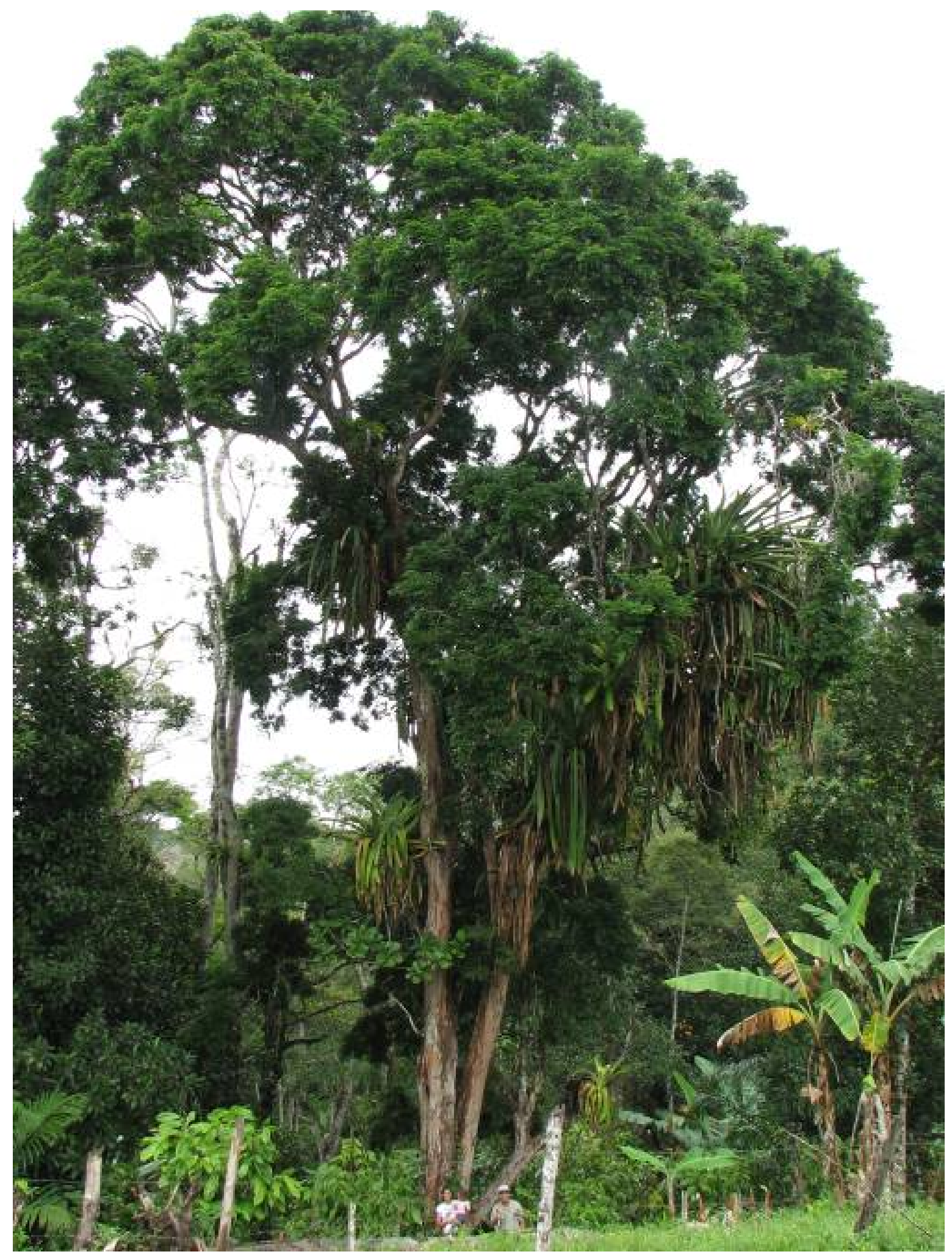

Figure 4: Brazil wood tree (Caesalpinia echinata) with high density of epiphytes in a cabruca in the region of Ilhéus where cabrucas represent most of the tree cover in the landscape (photo by G. Schroth). 


\section{Large mammals in an agroforestry mosaic in the Brazilian Atlantic forest}

Camila Righetto Cassano, Jos Barlow and Renata Pardini

Submetido para a revista Biotropica em 21 de julho de 2011 


\begin{abstract}
The forest-like characteristics of agroforestry systems create a unique opportunity to combine agricultural production with biodiversity conservation in human-modified tropical landscapes. The cacao growing region in southern Bahia, Brazil, encompasses Atlantic forest remnants and large extensions of agroforests, locally known as cabrucas, and harbors several endemic large mammals. Based on the differences between cabrucas and forests, we hypothesized that: (1) non-native and carnivore mammals that feed on small prey are more frequent, while arboreal, frugivore and hunted mammals are less frequent, in cabrucas than forests; (2) the two systems differ in assemblage structure and composition, but not in species richness; and (3) higher species turn-over occurs in cabrucas. We then used camera-traps to sample mammals in nine pairs of cabruca-forest sites. The high conservation value of the agroforests was supported by the presence of species of conservation concern in cabrucas, and similar species composition between forests and cabrucas. However, arboreal species were less frequently recorded, and non-native species and a carnivore adapted to open environments were more frequently recorded, in cabrucas. Additional factors that may overestimate the conservation value of cabrucas are: the high proportion of total forest cover in the study landscape, the apparent impoverishment of large mammal fauna in forest controls, and the uncertainty about long term maintenance of agroforestry systems. We highlight the importance of agroforests and forest remnants to provide connectivity in deforested tropical forest landscapes, but emphasize the importance of controlling hunting and dogs in order to increase the value of agroforestry mosaics.
\end{abstract}

Key words: Camera-trap; fragmentation; matrix; shade cacao plantation; Theobroma cacao; vertebrates 


\subsection{Introduction}

Protected areas have been created with the main purpose of biodiversity conservation. Nevertheless, they alone do not guarantee the maintenance of ecological processes over large spatial and temporal scales, and are dependent on the long term processes and dynamics of the surrounding landscape (Rosenzweig 2003, Rodrigues et al. 2004, Chazdon et al. 2009, Gardner et al. 2009). Human-modified landscapes are composed of a mosaic of environments with different degrees of suitability for the occurrence and dispersal of individuals from native and non-native species (Daily et al. 2003, Harvey et al. 2006, Harvey \& Villalobos 2007, Umetsu et al. 2008). Understanding changes in populations and communities between different environments and the linkages and dynamics across landscape mosaics are research priorities for conservation planning of tropical forests (Chazdon et al. 2009, Gardner et al. 2009).

In tropical forest regions, agroforestry systems represent an opportunity for the development of multi-functional landscapes that combine agricultural production and biodiversity conservation as they retain more forest-like characteristics than any other agricultural land-uses (Perfecto \& Vandermeer 2008). Landscapes harboring large extensions of cacao (Theobroma cacao) and coffee (Coffea arabica) agroforests have raised special conservation interest, since they occur in areas originally occupied by biologically-diverse tropical forest (Rice \& Greenberg 2000, Clough et al. 2009, Tscharntke et al. 2011). Species richness and abundance in cacao and coffee agroforests may parallel those of primary forest, but the composition and structure of communities usually differ. As a general rule, these shaded plantations harbor more generalist and fewer forest-dwelling species of small vertebrates and invertebrates than forests (Pardini et al. 2009, Waltert et al. 2011). However, species richness and composition in agroforests depends on the maintenance of forest cover at larger spatial scales, as has been shown in studies contrasting landscapes with different proportions of forest cover (Faria et al. 2007) or plantations at varying distances to the nearest forest (Bali et al. 2007). Moreover, landuse intensification - decreasing shade and shade diversity, and increasing agrochemical use - are negatively correlated with species richness (Perfecto et al. 2005, Gordon et al. 2007).

Large mammals play important roles in many ecosystems through a diverse array of mechanisms. These roles can be either played directly, via seed dispersal and predation (Tabarelli \& Peres 2002, Terborgh et al. 2008) or prey population control (Terborgh et al. 2001, Sinclair et al. 2003), or indirectly, by helping maintain assemblages of dung-beetles 
responsible for nutrient cycling, soil aeration and the secondary dispersal of seeds contained in mammal dung (Nichols et al. 2009). Many large mammals are threatened by habitat loss and disturbance, and overhunting is also a significant threat (Morrison et al. 2007) that can extirpate species from apparently intact forests (Redford 1992). The ease of access to forest remnants in highly fragmented landscapes increases both hunting pressure (Chiarello 1999, Cullen et al. 2000, Peres \& Nascimento 2006, Michalski \& Peres 2007, Galetti et al. 2009) and the damage caused by invasive species (e.g. domestic dogs Fiorello et al. 2006). Furthermore, human-wildlife conflicts resulting from crop damage and predation of livestock often result in the persecution and death of mammals (Naughton-Treves et al. 2003, Michalski et al. 2006a). Studies of large mammal communities in agroforestry systems have shown that species differ in their sensibility to the conversion of forest into agroforests, but species traits driving such responses are still poorly understood (Estrada et al. 1994, Harvey et al. 2006).

The Brazilian Atlantic forest has endured a long history of human influence, and current strategies for biodiversity conservation in this biome require the reestablishment of functional connectivity between forest remnants (Tabarelli et al. 2005, Ribeiro et al. 2009). The Atlantic forest from southeastern Bahia is recognized for its high species richness and endemism (Silva \& Casteleti 2003, Martini et al. 2007). It also encompasses large extensions of agroforests, with approximately $6000 \mathrm{~km}^{2}$ of land under cocoa plantations shaded by native trees (data from the years 1996/97; Landau et al. 2008). These agroforests are known regionally as cabrucas, and their management is likely to be of major importance for biodiversity conservation (Cassano et al. 2009).

Like other agroforestry systems, cabrucas are structurally simplified when compared to native forests; the canopy layer has lower tree diversity and density, the understory is exclusively composed by cacao trees and undergrowth vegetation is periodically removed by mechanical and chemical means (Sambuichi 2002). This structurally simplified vegetation has negative effects on species that disperse and forage through the vegetation, such as small arboreal rodents and marsupials, and understory birds (Moura 1999, Faria et al. 2006). The same negative effect can be expected on larger arboreal mammals as well as on frugivores, since this simplified vegetation should present lower fruit productivity. On the other hand, large mammals that feed on small vertebrates and insects might find higher food availability in cabrucas than in forests. The abundance of such prey is similar in cabrucas and forests (Faria et al. 2007, Pardini et al. 2009), but may be easier to capture in 
the more open cabrucas. Other differences in large mammal assemblages between cabrucas and forests are expected to result from the increased human and invasive species disturbance in managed agroforest compared to forest. Finally, there is also great variation in the implementation processes and management practices (Sambuichi \& Haridasan 2007) that might produce greater among-site variation in resources and disturbances, and thus higher beta diversity, within cabrucas than within forests.

Few studies have been conducted on the use of cabrucas by large mammals, and these focused on single, endangered species (Raboy et al. 2004, 2008; Cassano et al. 2011, Oliveira et al. 2011). We used camera-traps and a paired design of cabrucas and forest remnants to sample large mammals across a complex agroforestry mosaic in southern Bahia, and test the following hypotheses: (1) non-native and carnivore mammals that feed on small prey use cabrucas more frequently, while arboreal, frugivore and hunted mammals use these systems less frequently than forests; (2) consequently, the two systems differ in assemblage structure and composition, but not in richness (alpha diversity); and (3) species turn-over (beta diversity) is higher in cabrucas. We use our results to critically examine the conservation value of cabrucas.

\subsection{Methods}

\section{Study area and sampling design}

This study was carried out in the cacao growing region of southern Bahia, in a landscape encompassing part of the municipalities of Una and Arataca $\left(\sim 60 \mathrm{~km}^{2}\right.$; between $39^{\circ} 5^{\prime}-$ $39^{\circ} 22^{\prime} \mathrm{W}$ and $15^{\circ} 4^{\prime}-15^{\circ} 14^{\prime} \mathrm{S}$ ), largely covered by mature and late secondary forest (roughly $50 \%$ of the area; see Figure 1). The original vegetation is the Southern Bahian Wet Forest (Mori et al. 1983, Thomas 2003), which varies among lowland rainforest over latisols, lowland rainforest over podzols and montane forest (above the $500 \mathrm{~m}$ asl) from East to West in the study region (Thomas 2003). The mean annual temperature is $24^{\circ} \mathrm{C}$ and rainfall is around $2000 \mathrm{~mm} /$ year. There is no clear seasonality, although a warmer and rainless period usually occurs between December and March (Mori et al. 1983, Oliveira \& Fontes 2000).

The study sites were located in farms around and between two protected areas: the Una Biological Reserve in the East, and the Serra das Lontras National Park in the West. This agroforestry mosaic outside the reserves (Figure 1) is covered by 38 percent of mature and 
late secondary forests, and by 21, 20 and 10 percent of cabruca, pasture and permanent monocultures respectively. The land-use is strongly related to edaphic and topographic conditions, and larger forest patches persist in areas that are less favorable for the development of cacao plantations (sandy soils in the East and the steeper slopes in the West).

We sampled 18 sites located in nine blocks, each composed of a cabruca site and an adjacent site in a forest remnant (varying from tens to hundreds of hectares in size) 200 to $450 \mathrm{~m}$ apart from each other. The criteria for site selection were: (1) cacao plantations shaded mainly by native trees (excluding the more intense managed plantations) and adjacent to a forest remnant (used as a control); and (2) blocks were at least $2.5 \mathrm{~km}$ from each other (distances varied from 2.5 to $6.2 \mathrm{~km}$ ). The block design increased the power of our analysis by helping control for the variable landscape context, soil, and topography.

\section{Large mammal sampling}

Two camera-traps (analog Trapacamera - www.trapacamera.com) were placed in each site, one on the ground and one in the understory (3-4 m above ground level), 50 to $100 \mathrm{~m}$ apart from each other. Ground stations were baited with banana and sardine, and understory station just with banana. The position of cameras and the types of bait aimed at being able to sample terrestrial as well as arboreal, frugivoure as well as carnivore mammals. Cameratraps are frequently used to sample terrestrial large mammals (Silveira et al. 2003, Tobler et al. 2008a, Espartosa et al., in press) and have also proved effective for sampling arboreal species (Kierulff et al. 2004).

Data collection occurred during four sampling sessions in July-October of 2007 and 2008, and January-April of 2008 and 2009, when all sites were sampled. During each of the four sampling sessions, three cabruca-forest pairs were sampled simultaneously for four consecutive weeks and checked weekly to exchange film and re-bait (all nine pairs of sites sampled within four months). Nevertheless, the malfunction of camera-traps and the depletion of some films led to an unequal effort among sites and stations, which ranged from 90 to 127 trap day in forest sites and from 100 to 128 trap day in cabruca sites. The total sampling effort was 1895 and 2080 trap day, respectively. 
Species classification and expected responses to agroforest

The potential pool of 32 native large mammals occurring in the study region was identified following Moura (2003), excluding Pseudalopex vetulus which is not considered native to the region (Emmons \& Feer 1999). Species were classified as hunted or not following Cullen et al. (2000), Peres (2001), Naughton-Treves et al. (2003), Michalski et al. (2006a), Peres \& Nascimento (2006) and Whiteman et al. (2007). Hunted species included ungulates, armadillos, large primates and large rodents hunted for meat, and felids, which are often persecuted to protect livestock. We also included the opossum (Didelphis aurita) as it is known to be heavily hunted in the study region (Santos 1999). Classification of species according to dietary and locomotor habits followed Fonseca et al. (1996). Dietary classes were simplified to "frugivore", including all species that rely mainly on plant material with large proportion of fruit (frugivore/omnivore plus frugivore/herbivore) and "carnivore", including all species that include prey in their diet (omnivore plus carnivore).

From the 32 species, 14 were classified as hunted, 10 as arboreal, seven as frugivore and 19 as carnivore (Table 1). All species classified as frugivore were also either hunted or arboreal. Three species (Sylvilagus brasiliensis, Tamandua tetradactila and Lontra longicaudis) were not classified, but these were also rare or absent in our data and were not suitable for further analyses. Based on these classifications and our hypotheses, we expected 24 species to exhibit lower capture rates in cabrucas than forests and five to exhibit the opposite trend (Table 1).

\section{Data analysis}

The capture rate was calculated for each species and site by dividing the total number of records by the total sampling effort. A single record was defined as the presence of at least one picture of one species in one station during a 24-h period (starting at $0000 \mathrm{~h}$ ending at $2400 \mathrm{~h}$ ). To calculate sampling effort (trap-days) we only included days with no apparent camera-trap malfunction or film depletion. For arboreal and scansorial species we considered both ground-level and understory stations. We calculated capture rate by strata and then the average between them to prevent uneven effort between stations to bias capture rate. For terrestrial species, just the ground-level stations were considered. To compare the capture rate of each species between forests and cabrucas, we used a permutation test equivalent to a paired t-test, with 10,000 randomizations implemented in 
R 2.10.1 (R Development Core Team 2009). Only species recorded in at least four sites in one type of system (forests or cabrucas) were included in this analysis.

We used non-metric multi-dimensional scaling (MDS) and analysis of similarity (ANOSIM) to summarize and test for differences in assemblage structure and composition between forests and cabrucas. Analyses were run using square-root transformed capture rates (for structure) or presence-absence data (for composition) and Bray-Curtis distance. A similarity percentage analysis (SIMPER) was used to identify the contribution of each species to the dissimilarity in assemblage structure between forests and cabrucas (Clarke 1993). To test for differences in species turn-over (beta-diversity) between forests and cabrucas, we used an analysis of multivariate homogeneity of group dispersions and a permutation test (10,000 randomizations), which tests for differences in assemblage composition among groups contrasting the average dissimilarity from individual sites to their group centroid in multivariate space (Anderson et al. 2006). The MDS, ANOSIM and multivariate homogeneity of group dispersions analyses were implemented in R 2.10.1 (R Development Core Team 2009), using the Vegan package. SIMPER analysis was implemented in PRIMER 5.2.4 (Clarke \& Gorley 2006).

Alpha diversity was estimated for each site using Jackknife1 (as suggested by Tobler et al. 2008a,b) using sampling day as the unit of effort, and considering only the days in which both camera-traps (ground and understory stations) were working (78 to 126 days among sites). The abundance-based coverage (ACE) and the Chao1 estimators were also calculated and produced similar results, except for two cabruca sites with large number of rare species where alpha diversity estimated by ACE was 1.5 times larger than that found by other estimators. We compared differences in alpha diversity between forests and cabrucas using the same randomization procedure as previously described for species capture rates, and considering native species only. To examine gamma diversity, we constructed species accumulation curves with 95\% CI for each environment, considering sites as the unit of effort. To standardize sampling effort per site we only used records of native species from the first 78 days in which camera-traps in both stations per site worked simultaneously. Mean number of species and the $95 \%$ CI were calculated by the Mao Tau method, using EstimateS 8.2.0 (Cowell 2006). 


\subsection{Results}

We recorded 19 native and three non-native large mammal species in trap stations. Fifteen native and three non-native species were registered in forest remnants (1010 and 22 records, respectively), while 17 native and three non-native were registered in cabrucas (460 and 76 records, respectively; Table 1). Capture rates were higher but fewer species were recorded in understory stations. Four additional species that eluded the camera-trap stations were fortuitously detected once or twice in cabrucas (Bradypus torquatus, Pecari tajacu and Tamandua tetradactyla) and forest remnants (Callicebus melanochir) during the period of this study.

\section{Capture rates in forests and cabrucas}

Opossum (Didelphis aurita), black-tufted-ear marmoset (Callithrix kuhlii), golden-headed lion-tamarin (Leontopithecus chrysomelas), nine-banded armadillo (Dasypus novemcinctus), coati (Nasua nasua), tayra (Eira barbara), crab-eating raccoon (Procyon cancrivorus), crab-eating fox (Cerdocyon thous) and domestic cod (Canis familiaris) were recorded in at least four forest or cabruca sites. Our expectation that capture rate would be lower in cabrucas was met for both arboreal species (C. kuhlii and L. chrysomelas; Figure 2A-B). Our expectation that capture rate would be higher in cabrucas was met for the only non-native (C. familiars) and one carnivore species (C. thous; Figure 2H-I). The other carnivores (P. cancrivorus and N. nasua) and the hunted species (D. aurita and D. novemcinctus) had similar capture rates in forests and cabrucas, or did not match the expected pattern of distribution (E. barbara; Figure 2C-G).

\section{Assemblage metrics in forests and cabrucas}

The two-dimensional MDS shows that large mammal assemblages in forests and cabrucas were significantly distinct in structure (ANOSIM: $R=0.23, p<0.01$; Figure $3 \mathrm{~A}$ ), but not in species composition (ANOSIM: $R=-0.03, p=0.66$; Figure S1). The SIMPER analysis revealed that five species (the same for which capture rates varied significantly between the two systems) were responsible for $61 \%$ of the variation in assemblage structure between forests and cabrucas (Table S1). Capture rates of these species were plotted on the two-dimensional MDS plot (Figure 3B-F). 
Contrary to expectations, species turn-over (beta diversity) within cabrucas was not significantly greater than within forests (permutation test, $p=0.67$ ). However, as expected alpha diversity was similar between the two systems (permutation test, $p=0.44$ ), with an average of $7.6( \pm 1.8 \mathrm{SD})$ species in forest and $7.2( \pm 3.6 \mathrm{SD})$ species in cabruca sites (Figure 4A). Thus gamma diversity was also similar, and species accumulation curves were approaching their asymptote after nine samples (Figure 4B).

\subsection{Discussion}

We recorded 23 species during the study (including the four species fortuitously detected) compared to the 32 species of large mammals that Moura (2003) reported to be present in the largest forest remnants (the current protected areas) in the region. A simplistic interpretation of these numbers indicates that this agroforestry mosaic provides habitat for more than 70 percent of the native large mammal species. However, here we opted to critically assess the conservation value of cabrucas, first highlighting the results that help demonstrate the conservation value of these agroforests, second examining why this value should be viewed with caution, and finally discussing the importance of cabrucas at a regional scale.

\section{Evidence supporting the conservation value of cabrucas}

Our results on assemblage structure, composition and richness suggest that cabrucas have a high conservation value: they held as many species as forests in the mixed agroforestry mosaic, there was no significant change in species composition, and no evidence that different management practices led to a higher species turn-over. Although we did observe a significant difference in assemblage structure, these changes were generally much weaker than those previously reported in comparisons of large mammals between mature forest and either secondary forest or diverse shaded agroforests, where both assemblage structure and composition were significantly altered (Harvey et al. 2006, Barlow et al. 2007, Parry et al. 2007). Furthermore, the conservation value of cabrucas for large mammals was much higher than alternative anthropogenic land-uses such as urban areas (Crooks 2002), pastures (Daily et al. 2003), annual monocultures (Gehring \& Swihart 2003), banana (Harvey et al. 2006) and eucalyptus plantations (Barlow et al. 2007), all of which differ greatly from forests in terms of assemblage structure, composition and species 
richness. When compared to such land-uses, cabrucas are likely to increase both habitat availability and forest connectivity, increasing the population viability of forest-dependent species.

The records of species of conservation concern also support the high conservation value of cabrucas. The widespread presence of the threatened golden-headed lion-tamarin (Leonthopithecus chrysomelas) and the endemic marmoset (Callithix kuhlii), recorded in all forest and most of cabrucas sites, indicates that the agroforestry mosaic harbors a highly interconnected (meta)population of these species. Sparse records of other threatened mammals such as the maned sloth (Bradypus torquatus), the yellow-breasted capuchin monkey (Cebus xanthosternos) and the thin-spined porcupine (Chaetomys subspinosus) suggest that in some situations they might be able to enter and eventually inhabit cabrucas. This has been previously reported for B. torquatus, in a highly shaded cabruca in a farm bordering the Una Biological Reserve (Cassano et al. 2011), but the extent to which this species is able to utilize agroforests remains poorly understood.

Hunting pressure could reduce the value of cabrucas for large mammals, but we did not find any evidence that the impact of hunting was significantly higher in agroforests than in the forest remnants from the agroforestry mosaic. The two game species analyzed (the opossum, Didelphis aurita, and the nine-banded armadillo, Dasypus novemcinctus) had similar capture rates in forest and cabruca sites, which suggests they are adapted to changes in habitat and that hunting pressure does not decrease their use of the agroforests. The former is not surprising, as both species are common in forest fragments and agroforestry systems, and are well adapted to human-modified landscapes even when open environments are created (Estrada et al. 1994, Crooks 2002, Harvey et al. 2006, Michalski \& Peres 2007, Espartosa 2009). The latter indicates that hunting is not focused on the cabrucas where humans are more active, but it might be widespread across land-uses (see further discussion below). 
Questioning the conservation value of cabrucas

A number of factors indicate we should be cautious when interpreting our results regarding the high conservation value of cabrucas. The high proportion of forest in the study landscape is likely to improve local species richness and abundance. Furthermore, the paired nature of the study could complicate the extrapolation of our results to all cabrucas and forest remnants. Especially for highly vagile species, like large mammals, it is likely that the observed differences between environments would be stronger if we had compared the interior of large forest remnants with cabrucas isolated from forest patches.

Some species may still require forests, even if observed in cabrucas. For example, the capture rate of arboreal species (C. kuhlii e L. chrysomelas) was lower in cabrucas than in forests, indicating cabrucas represent sub-optimal habitat. The use of cabrucas by both species had been previously recorded (Raboy et al. 2004, Raboy et al. 2008), including groups of L. chrysomelas that had home ranges entirely within cabrucas in a landscape comprised mostly by cacao plantations (Oliveira et al. 2011). The two species are apparently well adapted to cabrucas with a high density of canopy trees (Raboy et al. 2004) or a high abundance of key food resources (e.g. jackfruit and bromeliads - Oliveira et al. 2011). As tree density and plant species diversity varies greatly between cabrucas (Sambuichi 2002, Sambuichi \& Haridasan 2007), not all cacao plantations should be expected to provide habitat for these primates. The tayra (E. barbara) was also recorded less frequently in cabrucas. The species was recorded in cacao and banana agroforests from Talamanca, Costa Rica (Harvey et al. 2006), but not in agroforests from southern Mexico (Estrada et al. 1994), where it was restricted to the larger forest remnants. The carnivore habit of species not persecuted by humans was not a good predictor of a high ability to use cabrucas as we predicted. Further investigation on the vertical use of the vegetation, of prey items and their availability in cabrucas should help to disentangle differences in carnivore responses.

Some of the species that benefit from agroforests are of little or no conservation concern. For example, both the non-native domestic dog (Canis familiaris) and the crab-eating fox (Cerdocyon thous), which is well adapted to open areas (Michalski \& Peres 2005, Michalski et al. 2006b), had higher capture rates in cabrucas. Clearly it is not intuitive to manage forested environments for open-area species such as $C$. thous, while the presence of domestic dogs can have many negative consequences for native fauna, from predation, 
competition and the spread of disease (Fiorello et al. 2006, Oliveira et al. 2008, Vanak \& Gompper 2009). Domestic dogs have been widely recorded in forest remnants (Fiorello et al. 2006, Whiteman et al. 2007, Srbek-Araujo \& Chiarello 2008, Espartosa 2009), and their distribution in forests has been related to the abundance they occur in nearby houses (Espartosa 2009) and also to the use of dogs by hunters (Fiorello et al. 2006, Whiteman et al. 2007). Domestic dogs were present at all properties within the study, and were frequently taken into cabrucas by the farm laborers (C.R. Cassano, pers. obs.). The widespread distribution of dogs through both forests and cabrucas certainly decrease the conservation value of the agroforestry mosaic for native fauna.

As in many tropical studies, our forest "controls" are likely to have a relatively low conservation value compared to the "original" state of southern Bahia Atlantic forest. Although we recorded a relatively large number of species in the cabrucas and the agroforestry mosaic, a significant number of species commonly reported in camera-trap studies from mature forests (e.g.: Silveira et al. 2003, Srbek-Araujo \& Chiarello 2005, Tobler et al. 2008a) were rare or absent in our data. Most of these species are frequently hunted or persecuted, including the ungulates (Pecary tajacu, Mazama spp.), large bodied primates and rodents (Cebus xanthosternos, Cuniculus paca, Dasyprocta aff. leporina.) and felids (Leopardus spp., Puma yagouaroundi, Puma concolor). Other species from these hunted groups that could occur in the area, such as the jaguar (Panthera onca), primates (Alouatta guariba, Brachyteles hypoxanthus) and ungulates (Tayassu pecari and Tapirus terrestris; Emmons \& Feer 1999), have not been recorded recently even within the largest forest remnants (Moura 2003). The rarity of these large bodied hunted species is further demonstrated by hunter preferences in the study region, as some of the smaller species (e.g. D. aurita) are listed amongst the most hunted (Santos 1999). The decline in these large-bodied animals is most likely explained by the local depletion of game stocks (Jerozolimski \& Peres 2003), and has also been reported in other landscapes with a high proportion of agroforestry systems (Harvey et al. 2006, Bali et al. 2007). This "shifted baseline" driven by hunting means we may overestimate the relative conservation value of the cabrucas, as these large-bodied species may also be vulnerable to land-use change. Recognition of such shifting baseline is important both to interpret observed results and to set conservation goals (Gardner et al. 2009).

Finally, it is important to balance the current conservation value against uncertainty regarding the long term future of cabrucas and the mosaic in which they lie. The absence 
of hunted mammals decreases large seed dispersal, which is likely to have cascading effects on tree community dynamics in tropical forests (Stoner et al. 2007, Terborgh et al. 2008). Tree impoverishment has already been observed in small forest remnants in the eastern part of the study landscape (Pardini et al. 2009) and elsewhere in the Atlantic forest (Santos 2008). Furthermore, tree regeneration is strongly influenced by management in agroforests, and in older cabrucas the composition of the shade trees is increasingly dominated by fast growing native species (pioneers and species found in young secondary forests) and exotic tree species (Sambuichi \& Haridasan 2007). Other long-term trends include the thinning of the canopy layer and the replacement of agroforests by other landuses (Clough et al. 2009). This latter activity can result in further deforestation of native forest for the establishment of new cacao plantations. This cacao "boom and bust" cycle (Clough et al. 2009) has not yet become widespread in the southern Bahia cacao growing region, despite the long time since the first cacao plantations started in this region. However, it has been occurring on a small scale (either through management practices intensification or land-use change) and remains as a potential threat (Schroth et al. 2011).

\section{Implications for the conservation of large mammals in southern Bahia}

While our results are intended to provide information about the value of cacao agroforests for large mammals, they are also informative about the importance of these systems in the specific landscape we worked in. The forest-cabruca mosaic dominates the landscape between Una Biological Reserve and Serra das Lontras National Park, and potentially constitutes an important biodiversity corridor, increasing habitat availability and decreasing patch isolation for large mammals. However, the scarcity of game species in our study indicates that the functionality of this corridor is severely impaired by past and present hunting pressure and the presence of domestic dogs in the cabrucas and forest remnants.

Our results also help underline the importance of maintaining large forest remnants. The large areas of forest may provide the only habitat for species that are sensitive to the synergetic effects of forest fragmentation, overhunting and the invasion of non-native species, while smaller forest remnants might represent higher quality habitat patches within the agroforestry mosaic for some species of conservation concern, such as L. chrysomelas. The importance of maintaining forest remnants in this landscape is even higher considering 
that cabrucas are agricultural environments, and economic pressures may lead to land-use intensification and change (Schroth et al. 2011).

\subsection{Conclusion}

Given the increasing demand for food and other agricultural products, the implementation of large scale "wildlife-friendly" but low productive agroforestry systems has been questioned (Balmford et al. 2005). In this paper we demonstrate how cacao agroforests in a mixed forest and agroforestry landscape can be beneficial for large mammal conservation, considering a range of responses to the conversion of forests to cabrucas. Because biodiversity conservation in protected areas will increase if functional connectivity at a broad scale exists, wildlife-friendly land-uses may benefit even species that are unable to use it as permanent habitat, and therefore deserve attention of researches and resource managers. Moreover, diverse and highly shaded agroforests can confer higher resilience to ecosystems and help maintain environmental services (Tscharntke et al. 2005). Agroforests also deliver socio-economic benefits to the rural poor being a lower intake and more resilient productive systems (Perfecto \& Vandermeer 2008), and providing income from exploitation of other (not the main crop) food and non-food resources (Tscharntke et al. 2011).

\section{Acknowledgments}

This paper benefited from grants from the European Union, the Brazilian Ministry of the Environment and Seeds of Change. CRC acknowledge her scholarship from FAPESP (07/54888-1), and is grateful to her field assistant, Rubens Vieira Lopes, and the owners and employees of the farms were the study was developed. We thank Ricardo Faustino de Lima for valuable comments on an early version of this manuscript. 


\section{References}

Anderson, M. J., K. E. Ellingsen, and B. H. MCArdle. 2006. Multivariate dispersion as a measure of beta diversity. Ecol. Lett. 9: 683-693.

Bali, A., A. Kumar, and J. Krishnaswamy. 2007. The mammalian communities in coffee plantations around a protected area in the Western Ghats, India. Biol. Conserv. 139: 93-102.

Balmford, A., R. E. Green, and J. P. W. Scharlemann. 2005. Sparing land for nature: Exploring the potential impact of changes in agricultural yield on the area needed for crop production. Global Change Biology 11: 1594-1605.

Barlow, J., T. A. Gardner, I. S. Araujo, T. C. Avila-Pires, A. B. Bonaldo, J. E. Costa, M. C. Esposito, L. V. Ferreira, J. Hawes, M. M. Hernandez, M. S. Hoogmoed, R. N. Leite, N. F. Lo-Man-Hung, J. R. Malcolm, M. B. Martins, L. A. M. Mestre, R. Miranda-Santos, A. L. Nunes-Gutjahr, W. L. Overal, L. Parry, S. L. Peters, M. A. Ribeiro-Junior, M. N. F. DA Silva, C. D. Motta, and C. A. PERES. 2007. Quantifying the biodiversity value of tropical primary, secondary, and plantation forests. Proc. Natl. Acad. Sci. USA 104: 18555-18560.

Cassano, C. R., M. C. M. Kierulff, and A. G. Chiarello. 2011. The cacao agroforests of the Brazilian Atlantic forest as habitat for the endangered maned sloth Bradypus torquatus. Mammalian Biology 76: 243-250.

Cassano, C. R., G. Schroth, D. Faria, J. H. C. Delabie, and L. Bede. 2009. Landscape and farm scale management to enhance biodiversity conservation in the cocoa producing region of southern Bahia, Brazil. Biodiversity Conserv. 18: 577-603.

Chazdon, R. L., C. A. Harvey, O. Komar, D. M. Griffith, B. G. Ferguson, M. Martinez-Ramos, H. Morales, R. Nigh, L. Soto-Pinto, M. van Breugel, and S. M. PhiLPOTT. 2009. Beyond Reserves: A research agenda for conserving biodiversity in human-modified tropical landscapes. Biotropica 41: 142-153.

Chiarello, A. G. 1999. Effects of fragmentation of the Atlantic forest on mammal communities in south-eastern Brazil. Biol. Conserv. 89: 71-82.

Clarke, K. R. 1993. Non-parametric multivariate analyses of changes in community structure. Aust. J. Ecol. 18: 117-143. 
Clarke, K. R., and R. N. Gorley. 2006. PRIMER v6: User Manual/Tutorial. PRIMER-E, Plymont.

Clough, Y., H. FAust, and T. TsCharnTKE. 2009. Cacao boom and bust: Sustainability of agroforests and opportunities for biodiversity conservation. Conservation Letters 2: 197-205.

COWELL, R. K. 2006. EstimateS: Statistical estimation of species richness and shared species from samples. Version 8. Persistent IRL < purl.oclc.org/estimates>.

Crooks, K. R. 2002. Relative sensitivities of mammalian carnivores to habitat fragmentation. Conserv. Biol. 16: 488-502.

Cullen, L., R. E. Bodmer, and C. V. PADUA. 2000. Effects of hunting in habitat fragments of the Atlantic forests, Brazil. Biol. Conserv. 95: 49-56.

Daily, G. C., G. Ceballos, J. Pacheco, G. Suzan, and A. Sanchez-Azofeifa. 2003. Countryside biogeography of neotropical mammals: Conservation opportunities in agricultural landscapes of Costa Rica. Conserv. Biol. 17: 1814-1826.

EMmons, L. H., and F. FeER. 1999. Neotropical Rainforest Mammals: A Field Guide. The University of Chicago Press, Chicago, CA.

EspartosA, K. D. 2009. Mamíferos terrestres de maior porte e a invasão de cães domésticos em remanescentes de uma paisagem fragmentada de Mata Atlântica: avaliação da eficiência de métodos de amostragem e da importância de múltiplos fatores sobre a distribuição das especies. MSc Dissertation, Universidade de São Paulo, São Paulo, SP.

Espartosa, K. D., B. T. PinOtTI, and R. PARdini. in press. Performance of camera trapping and track counts for surveying large mammals in rainforest remnants. Biodiversity Conserv.

Estrada, A., R. Coatesestrada, and D. Meritt. 1994. Non-flying mammals and landscape changes in the tropical rain-forest region of Los-Tuxtlas, Mexico. Ecography 17: 229-241.

Faria, D., R. R. Laps, J. Baumgarten, and M. Cetra. 2006. Bat and bird assemblages from forests and shade cacao plantations in two contrasting landscapes in the Atlantic forest of southern Bahia, Brazil. Biodiversity Conserv. 15: 587-612. 
Faria, D., M. L. B. Paciencia, M. Dixo, R. R. LAPS, and J. BAumgarten. 2007. Ferns, frogs, lizards, birds and bats in forest fragments and shade cacao plantations in two contrasting landscapes in the Atlantic forest, Brazil. Biodiversity Conserv. 16: 23352357.

Fiorello, C. V., A. J. Noss, and S. L. DeEm. 2006. Demography, hunting ecology, and pathogen exposure of domestic dogs in the Isoso of Bolivia. Conserv. Biol. 20: 762771.

Fonseca, G. A. B., G. Herrmann, Y. L. R. Leite, R. A. Mittermeier, A. B. Rylands, and J. L. Patton. 1996. Lista Anotada dos Mamíferos do Brasil. Conservation International, Washington, DC.

Galetti, M., H. C. Giacomini, R. S. Bueno, C. S. S. Bernardo, R. M. Marques, R. S. Bovendorp, C. E. Steffler, P. Rubim, S. K. Gobbo, C. I. Donatti, R. A. Begotti, F. Meirelles, R. D. Nobre, A. G. Chiarello, and C. A. Peres. 2009. Priority areas for the conservation of Atlantic forest large mammals. Biol. Conserv. 142: 1229-1241.

Gardner, T. A., J. Barlow, R. Chazdon, R. M. Ewers, C. A. Harvey, C. A. Peres, and N. S. SoDHI. 2009. Prospects for tropical forest biodiversity in a human-modified world. Ecol. Lett. 12: 561-582.

Gehring, T. M., and R. K. Swihart. 2003. Body size, niche breadth, and ecologically scaled responses to habitat fragmentation: Mammalian predators in an agricultural landscape. Biol. Conserv. 109: 283-295.

Gordon, C., R. Manson, J. Sundberg, and A. Cruz-Angón. 2007. Biodiversity, profitability, and vegetation structure in a Mexican coffee agroecosystem. Agric., Ecosyst. Environ. 118: 256-266.

Harvey, C. A., J. Gonzalez, and E. SomarribA. 2006. Dung beetle and terrestrial mammal diversity in forests, indigenous agroforestry systems and plantain monocultures in Talamanca, Costa Rica. Biodiversity Conserv. 15: 555-585.

Harvey, C. A., and J. A. G. Villalobos. 2007. Agroforestry systems conserve speciesrich but modified assemblages of tropical birds and bats. Biodiversity Conserv. 16: 2257-2292. 
Jerozolimski, A., and C. A. Peres. 2003. Bringing home the biggest bacon: A cross-site analysis of the structure of hunter-kill profiles in Neotropical forests. Biol. Conserv. 111: 415-425.

Kierulff, M. C. M., G. R. Santos, G. Canale, C. E. Guidorizzi, and C. R. Cassano. 2004. The use of camera-traps in a survey of the buff-headed capuchin monkey, Cebus xanthosternos. Neotropical Primates 12: 56-59.

Landau, E. C., A. Hirsch, and J. MusinKy. 2008. Vegetation cover and land use in the Atlantic forest of southern Bahia, Brazil, based on satellite imagery: A comparison among municipalities. In: W. W. Thomas and E. G. Britton (Eds.). The Atlantic Coastal Forest of Northeastern Brazil. The New York Botanical Garden Press, New York, NY, pp. 221-244

Martini, A. M. Z., P. Fiaschi, A. M. Amorim, and J. L. DA PaiXaO. 2007. A hot-point within a hot-spot: A high diversity site in Brazil's Atlantic forest. Biodiversity Conserv. 16: 3111-3128.

Michalski, F., R. L. P. Boulhosa, A. Faria, and C. A. Peres. 2006a. Human-wildlife conflicts in a fragmented Amazonian forest landscape: Determinants of large felid depredation on livestock. Animal Conservation 9: 179-188.

Michalski, F., P. G. Crawshaw, T. G. De Oliveira, and M. E. Fabian. 2006b. Notes on home range and habitat use of three small carnivore species in a disturbed vegetation mosaic of southeastern Brazil. Mammalia 70: 52-57.

Michalski, F., and C. A. Peres. 2005. Anthropogenic determinants of primate and carnivore local extinctions in a fragmented forest landscape of southern Amazonia. Biol. Conserv. 124: 383-396.

Michalski, F., and C. A. Peres. 2007. Disturbance-mediated mammal persistence and abundance-area relationships in Amazonian forest fragments. Conserv. Biol. 21: 16261640.

Mori, S. A., B. M. Boom, A. M. Carvalho, and T. S. Santos. 1983. Southern Bahia moist forest. The Botanical Review 49: 155-232.

Morrison, J. C., W. Sechrest, E. Dinerstein, D. S. Wilcove, and J. F. Lamoreux. 2007. Persistence of large mammal faunas as indicators of global human impacts. J. Mammal. 88: 1363-1380. 
MourA, R. T. 1999. Análise comparativa da estrutura de comunidades de pequenos mamíferos em remanescente de Mata Atlântica e em plantio de cacau em sistema de cabruca no sul da Bahia. MSc Dissertation, Universidade Federal de Minas Gerais, Belo Horizonte, MG.

MourA, R. T. 2003. Distribuição e ocorrência de mamíferos na Mata Atlântica do sul da Bahia. In: P. I. Prado, E. C. Landau, R. T. Moura, L. P. Pinto, K. Alger and G. A. B. Fonseca (Eds.). Corredor de Biodiversidade da Mata Atlântica do Sul da Bahia. IESB/CI/CABS/UFMG/UNICAMP, Ilhéus, BA, CD-Room.

Naughton-Treves, L., J. L. Mena, A. Treves, N. Alvarez, and V. C. Radeloff. 2003. Wildlife survival beyond park boundaries: The impact of slash-and-burn agriculture and hunting on mammals in Tambopata, Peru. Conserv. Biol. 17: 1106-1117.

Nichols, E., T. A. Gardner, C. A. Peres, and S. Spector. 2009. Co-declining mammals and dung beetles: An impending ecological cascade. Oikos 118: 481-487.

Oliveira, A. T., and M. A. L. Fontes. 2000. Patterns of floristic differentiation among Atlantic forests in southeastern Brazil and the influence of climate. Biotropica 32: 793-810.

Oliveira, L. C., L. G. Neves, B. E. Raboy, and J. Dietz. 2011. Abundance of jackfruit (Artocarpus heterophyllus) affects group characteristics and use of space by goldenheaded lion-tamarins (Leontopithecus chrysomelas) in cabruca agroforest. Environ. Manage. 48: 248-262.

Oliveira, V. B., A. M. Linares, G. L. C. CorrêA, and A. G. Chiarello. 2008. Predation on the black capuchin monke Cebus nigritus (Primates: Cebidae) by domestic dogs Canis lupus familiaris (Carnivoa: Canidae), in the Parque Estadual Serra do Brigadeiro, Minas Gerais, Brazil. Revista Brasileira de Zoologia 23: 376-378.

Pardini, R., D. Faria, G. M. Accacio, R. R. Laps, E. Mariano-Neto, M. L. B. Paciencia, M. Dixo, and J. Baumgarten. 2009. The challenge of maintaining Atlantic forest biodiversity: A multi-taxa conservation assessment of specialist and generalist species in an agro-forestry mosaic in southern Bahia. Biol. Conserv. 142: $1178-1190$.

PARry, L., J. BARlow, and C. A. Peres. 2007. Large-vertebrate assemblages of primary and secondary forests in the Brazilian Amazon. J. Trop. Ecol. 23: 653-662. 
PERES, C. A. 2001. Synergistic effects of subsistence hunting and habitat fragmentation on Amazonian forest vertebrates. Conserv. Biol. 15: 1490-1505.

Peres, C. A., and H. S. NAscimento. 2006. Impact of game hunting by the Kayapo of south-eastern Amazonia: Implications for wildlife conservation in tropical forest indigenous reserves. Biodiversity Conserv. 15: 2627-2653.

Perfecto, I., and J. VAndermeer. 2008. Biodiversity conservation in tropical agroecosystems - A new conservation paradigm. Ann. N.Y. Acad. Sci. 1134: 173-200.

Perfecto, I., J. Vandermeer, A. Mas, and L. S. Pinto. 2005. Biodiversity, yield, and shade coffee certification. Ecological Economics 54: 435-446.

R Development Core Team. 2009. R: a language and environment for statistical computing. R Foundation for Statistical Computing. Viena. Available: http://www.Rproject.org. Accessed December 2009.

Raboy, B. E., G. R. Canale, and J. M. Dietz. 2008. Ecology of Callithrix kuhlii and a review of eastern Brazilian marmosets. Int. J. Primatol. 29: 449-467.

Raboy, B. E., M. C. Christman, and J. M. Dietz. 2004. The use of degraded and shade cocoa forests by endangered golden-headed lion-tamarins Leontopithecus chrysomelas. Oryx 38: 75-83.

REDFORD, K. H. 1992. The empty forest. Bioscience 42: 412-422.

Ribeiro, M. C., J. P. Metzger, A. C. Martensen, F. J. Ponzoni, and M. M. Hirota. 2009. The Brazilian Atlantic forest: How much is left, and how is the remaining forest distributed? Implications for conservation. Biol. Conserv. 142: 1141-1153.

Rice, R. A., and R. GreEnBerg. 2000. Cacao cultivation and the conservation of biological diversity. Ambio 29: 167-173.

Rodrigues, A. S. L., S. J. Andelman, M. I. Bakarr, L. Boitani, T. M. Brooks, R. M. Cowling, L. D. C. Fishrool, G. A. B. Da Fonseca, K. J. Gaston, M. Hoffmann, J. S. Long, P. A. Marquet, J. D. Pilgrim, R. L. Pressey, J. Schipper, W. Sechrest, S. N. Stuart, L. G. Underhill, R. W. Waller, M. E. J. Watts, and X. Yan. 2004. Effectiveness of the global protected area network in representing species diversity. Nature 428: 640-643. 
RosenzWeIG, M. L. 2003. Reconciliation ecology and the future of species diversity. Oryx 37: 194-205.

SAMBUICHI, R. H. R. 2002. Fitossociologia e diversidade de espécies arbóreas em cabruca (Mata Atlântica raleada sobre plantaçao de cacau) na região sul da Bahia, Brasil. Acta Botanica Brasilica 16: 89-101.

SAMBUiCHI, R. H. R., and M. HARIDASAN. 2007. Recovery of species richness and conservation of native Atlantic forest trees in the cacao plantations of southern Bahia in Brazil. Biodiversity Conserv. 16: 3681-3701.

Santos, B. A., C. A. Peres, M. A. Oliveira, A. Grillo, C. P. Alves-Costa, And M. TABARELl. 2008. Drastic erosion in functional attributes of tree assemblages in Atlantic forest fragments of northeastern Brazil. Biol. Conserv. 141: 249-260.

SANTOS, G. R. 1999. Caracterizacão da caça na região do entorno da Reserva Biológica de Una-BA. Projeto Remanescentes de Florestas na Região de Una, BA, RestaUna/PROBIO, Ilhéus, BA.

Schroth, G., D. Faria, L. Bede, S. A. Van Bael, C. R. Cassano, L. C. Oliveira, and J. H. C. Delabie. 2011. Conservation in tropical landscape mosaics: The case of the cacao landscape of southern Bahia, Brazil. Biodiversity Conserv. 20: 1635-1654.

Silva, J. M. C., and C. H. Casteleti. 2003. Status of the biodiversity of the Atlantic Forest of Brazil. In: C. Gallino-Leal and I. G. Câmara (Eds.). The Atlantic Forest of South America: Biodiversity, Threats, and Outlook. Island Press, Washington, DC, pp. 43-59.

Silveira, L., A. T. A. JACOMO, and J. A. F. Diniz. 2003. Camera trap, line transect census and track surveys: A comparative evaluation. Biol. Conserv. 114: 351-355.

Sinclair, A. R. E., S. Mduma, and J. S. Brashares. 2003. Patterns of predation in a diverse predator-prey system. Nature 425: 288-290.

Srbek-Araujo, A. C., and A. G. Chiarello. 2005. Is camera-trapping an efficient method for surveying mammals in neotropical forests? A case study in south-eastern Brazil. J. Trop. Ecol. 21: 121-125.

Srbek-Araujo, A. C., and A. G. Chiarello. 2008. Domestic dogs in Atlantic forest preserves of south-eastern Brazil: A camera-trapping study on patterns of entrance and site occupancy rates. Brazilian Journal of Biology 68: 771-779. 
Stoner, K. E., K. Vulinec, S. J. Wright, and C. A. Peres. 2007. Hunting and plant community dynamics in tropical forests: A synthesis and future directions. Biotropica 39: 385-392.

Tabarelli, M., and C. A. Peres. 2002. Abiotic and vertebrate seed dispersal in the Brazilian Atlantic forest: Implications for forest regeneration. Biol. Conserv. 106: 165176.

Tabarelli, M., L. P. Pinto, J. M. C. Silva, M. Hirota, and L. Bede. 2005. Challenges and opportunities for biodiversity conservation in the Brazilian Atlantic forest. Conserv. Biol. 19: 695-700.

Terborgh, J., L. Lopez, P. Nunez, M. RaO, G. Shahabuddin, G. Orihuela, M. Riveros, R. Ascanio, G. H. Adler, T. D. Lambert, and L. Balbas. 2001. Ecological meltdown in predator-free forest fragments. Science 294: 1923-1926.

Terborgh, J., G. Nunez-Iturri, N. C. A. Pitman, F. H. C. Valverde, P. Alvarez, V. Swamy, E. G. Pringle, and C. E. T. PAine. 2008. Tree recruitment in an empty forest. Ecology 89: 1757-1768.

Thomas, W. W. 2003. Natural vegetation types in southern Bahia. In: P. I. Prado, E. C. Landau, R. T. Moura, L. P. Pinto, K. Alger and G. A. B. Fonseca (Eds.). Corredor de Biodiversidade da Mata Atlântica do Sul da Bahia. IESB/CI/CABS/UFMG/UNICAMP, Ilhéus, CD-Room.

Tobler, M. W., S. E. Carrillo-Percastegui, R. L. Pitman, R. Mares, and G. Powell. 2008a. An evaluation of camera traps for inventorying large- and medium-sized terrestrial rainforest mammals. Animal Conservation 11: 169-178.

Tobler, M. W., S. E. Carrillo-Percastegui, R. L. Pitman, R. Mares, and G. Powell. 2008 b. Further notes on the analysis of mammal inventory data collected with camera traps. Animal Conservation 11: 187-189.

Tscharntke, T., Y. Clough, S. A. Bhagwat, D. Buchori, H. Faust, D. Hertel, D. Holscher, J. Juhrbandt, M. Kessler, I. Perfecto, C. Scherber, G. Schroth, E. VELDKAMP, and T. C. WANGER. 2011. Multifunctional shade-tree management in tropical agroforestry landscapes - A review. J. Appl. Ecol. 48: 619-629. 
Tscharntke, T., A. M. Klein, A. Kruess, I. Steffan-Dewenter, and C. Thies. 2005. Landscape perspectives on agricultural intensification and biodiversity - Ecosystem service management. Ecol. Lett. 8: 857-874.

Umetsu, F., J. P. MetzGer, and R. PARDinI. 2008. Importance of estimating matrix quality for modeling species distribution in complex tropical landscapes: A test with Atlantic forest small mammals. Ecography 31: 359-370.

VanaK, A. T., and M. E. Gomprer. 2009. Dogs Canis familiaris as carnivores: Their role and function in intraguild competition. Mamm. Rev. 39: 265-283.

Waltert, M., K. S. Bobo, S. Kaupa, M. L. Montoya, M. S. Nsanyi, and H. Fermon. 2011. Assessing conservation values: Biodiversity and endemicity in tropical land use systems. Plos One 6: e16238.

Whiteman, C. W., E. R. Matushima, U. E. C. Confalonieric, M. D. C. Palha, A. D. L. DA Silva, and V. C. MonTEIRO. 2007. Human and domestic animal populations as a potential threat to wild carnivore conservation in a fragmented landscape from the Eastern Brazilian Amazon. Biol. Conserv. 138: 290-296. 
Table 1: Large mammals potentially occurring in the forest-agroforest mosaic (following Moura 2003), showing: (1) classification of commonly hunted species, locomotor and diet habits; (2) the number of capture records per type of camera-trap station (on the ground or understory) and per system (forests and cabrucas), as well as the number of sites species were recorded; and (3) the predicted and observed responses to conversion of forest to cabrucas: arrows indicate greater or smaller capture rates in cabrucas than in forests, zero indicates no directional response and "na" stands for species not analyzed.

\begin{tabular}{|c|c|c|c|c|c|c|c|c|c|c|c|c|c|}
\hline \multirow[b]{2}{*}{ Species } & \multicolumn{3}{|c|}{ 1. Classification } & \multicolumn{4}{|c|}{ 2. Forest } & \multicolumn{4}{|c|}{ Cabruca } & \multicolumn{2}{|c|}{ 3. Response } \\
\hline & 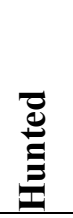 & 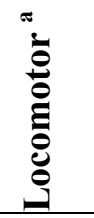 & $\stackrel{0}{\circ}$ & 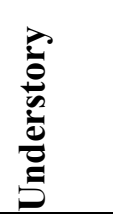 & 를 & है & 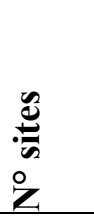 & $\begin{array}{l}\overrightarrow{0} \\
\stackrel{0}{0} \\
\frac{0}{0} \\
\stackrel{0}{0} \\
0\end{array}$ & $\underset{0}{0}$ & & 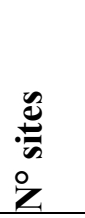 & : & $\begin{array}{l}\text { D. } \\
\sum_{0}^{0} \\
0 \\
0 \\
0 \\
0\end{array}$ \\
\hline \multicolumn{14}{|l|}{ Order Didelphimorphia } \\
\hline Didelphis aurita & $\mathrm{x}$ & $\mathrm{SC}$ & $\mathrm{CR}$ & 6 & 30 & 36 & 7 & 6 & 20 & 26 & 7 & $\downarrow$ & 0 \\
\hline \multicolumn{14}{|l|}{ Order Cingulata } \\
\hline Cabassous sp. & $\mathrm{x}$ & $\mathrm{SF}$ & & 0 & 4 & 4 & 2 & 0 & 2 & 2 & 2 & $\downarrow$ & na \\
\hline Dasypus novemcinctus & $\mathrm{x}$ & $\mathrm{TE}$ & & 0 & 6 & 6 & 4 & 0 & 2 & 2 & 2 & $\downarrow$ & 0 \\
\hline Euphractus sexcinctus & $\mathrm{x}$ & SF & & 0 & 0 & 0 & 0 & 0 & 2 & 2 & 1 & $\downarrow$ & na \\
\hline \multicolumn{14}{|l|}{ Order Pilosa } \\
\hline Bradypus variegatus & & AR & & & & & & & & & & $\downarrow$ & na \\
\hline Bradypus torquatus & & AR & & & & & & & & & & $\downarrow$ & na \\
\hline Tamandua tetradactyla & & $\mathrm{SC}$ & & & & & & & & & & & na \\
\hline \multicolumn{14}{|l|}{ Order Primates } \\
\hline Callicebus melanochir & $\mathrm{x}$ & AR & $\mathrm{CR}$ & & & & & & & & & $\downarrow$ & na \\
\hline Callithrix kuhlii & $\mathrm{x}$ & AR & $\mathrm{CR}$ & 377 & 83 & 460 & 9 & 161 & 39 & 200 & 8 & $\downarrow$ & $\downarrow$ \\
\hline Cebus xanthosternos & & AR & $\mathrm{CR}$ & 2 & 1 & 3 & 1 & 3 & 0 & 3 & 1 & $\downarrow$ & na \\
\hline Leontopithecus chrysomelas & & AR & $\mathrm{CR}$ & 290 & 89 & 379 & 9 & 100 & 20 & 120 & 7 & $\downarrow$ & $\downarrow$ \\
\hline \multicolumn{14}{|l|}{ Order Lagomorpha } \\
\hline Sylvilagus brasiliensis & & $\mathrm{TE}$ & & 0 & 0 & 0 & 0 & 0 & 1 & 1 & 1 & & na \\
\hline
\end{tabular}


Table 1 (cont.)

\begin{tabular}{|c|c|c|c|c|c|c|c|c|c|c|c|c|c|}
\hline \multirow[b]{2}{*}{ Species } & \multirow{2}{*}{\multicolumn{3}{|c|}{ 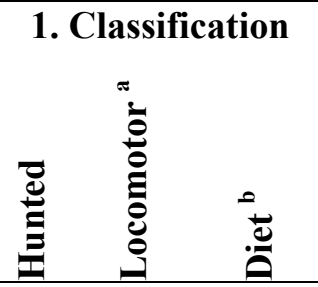 }} & \multicolumn{4}{|c|}{ 2. Forest } & \multicolumn{4}{|c|}{ Cabruca } & \multicolumn{2}{|c|}{ 3. Response } \\
\hline & & & & 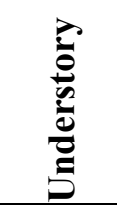 & 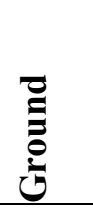 & $\stackrel{\overline{\tilde{\sigma}}}{\underline{\theta}}$ & $\begin{array}{l}\stackrel{n}{0} \\
\stackrel{\tilde{n}}{n} \\
\stackrel{0}{Z}\end{array}$ & 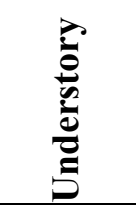 & 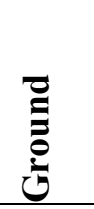 & हैّ & 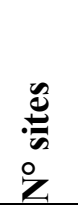 & 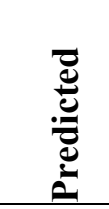 & $\begin{array}{l}\overrightarrow{0} \\
0 \\
0 \\
0 \\
0 \\
0\end{array}$ \\
\hline \multicolumn{14}{|l|}{ Order Rodentia } \\
\hline Chaetomys subspinosus & & $\mathrm{AR}$ & FR & 0 & 0 & 0 & 0 & 0 & 1 & 1 & 1 & $\downarrow$ & na \\
\hline Cuniculus paca & $\mathrm{x}$ & $\mathrm{TE}$ & FR & 0 & 10 & 10 & 3 & 0 & 15 & 15 & 1 & $\downarrow$ & na \\
\hline Dasyprocta aff. leporina & $\mathrm{x}$ & $\mathrm{TE}$ & FR & 0 & 1 & 1 & 1 & 0 & 0 & 0 & 0 & $\downarrow$ & na \\
\hline Guerlinguetus ingrami & & AR & $\mathrm{CR}$ & & & & & & & & & $\downarrow$ & na \\
\hline Hydrochoerus hydrochaeris & $\mathrm{x}$ & SA & & & & & & & & & & $\downarrow$ & na \\
\hline Sphigurus insidiosus & & $\mathrm{AR}$ & FR & 0 & 0 & 0 & 0 & 1 & 0 & 1 & 1 & $\downarrow$ & na \\
\hline \multicolumn{14}{|l|}{ Order Carnivora } \\
\hline Cerdocyon thous & & $\mathrm{TE}$ & $\mathrm{CR}$ & 0 & 17 & 17 & 8 & 0 & 50 & 50 & 7 & $\uparrow$ & $\uparrow$ \\
\hline Eira barbara & & $\mathrm{SC}$ & $\mathrm{CR}$ & 1 & 43 & 44 & 6 & 0 & 8 & 8 & 3 & $\uparrow$ & $\downarrow$ \\
\hline Galictis vittata & & $\mathrm{TE}$ & $\mathrm{CR}$ & & & & & & & & & $\uparrow$ & na \\
\hline Lontra longicaudis & & SA & $\mathrm{CR}$ & & & & & & & & & & \\
\hline Leopardus pardalis & $\mathrm{x}$ & $\mathrm{TE}$ & $\mathrm{CR}$ & & & & & & & & & $\downarrow$ & na \\
\hline Leopardus sp. & $\mathrm{x}$ & $\mathrm{SC}$ & $\mathrm{CR}$ & 0 & 1 & 1 & 1 & 0 & 0 & 0 & 0 & $\downarrow$ & na \\
\hline Nasua nasua & & $\mathrm{SC}$ & $\mathrm{CR}$ & 13 & 18 & 31 & 4 & 2 & 0 & 2 & 2 & $\uparrow$ & 0 \\
\hline Potus flavus & & $\mathrm{AR}$ & $\mathrm{CR}$ & 4 & 0 & 4 & 2 & 1 & 0 & 1 & 1 & $\downarrow$ & na \\
\hline Procyon cancrivorus & & $\mathrm{SC}$ & $\mathrm{CR}$ & 0 & 13 & 13 & 5 & 2 & 23 & 25 & 6 & $\uparrow$ & 0 \\
\hline Puma yagouaroundi & $\mathrm{x}$ & $\mathrm{TE}$ & $\mathrm{CR}$ & & & & & & & & & $\downarrow$ & na \\
\hline Puma concolor & $\mathrm{x}$ & $\mathrm{TE}$ & $\mathrm{CR}$ & & & & & & & & & $\downarrow$ & na \\
\hline \multicolumn{14}{|l|}{ Order Artiodactyla } \\
\hline Mazama sp. ${ }^{\mathrm{c}}$ & $\mathrm{x}$ & $\mathrm{TR}$ & FR & 0 & 1 & 1 & 1 & 0 & 1 & 1 & 1 & $\downarrow$ & na \\
\hline Pecari tajacu & $\mathrm{x}$ & TR & FR & & & & & & & & & $\downarrow$ & na \\
\hline Total native & & & & 693 & 317 & 1010 & & 276 & 184 & 460 & & & \\
\hline
\end{tabular}


Table 1 (cont.)

\begin{tabular}{|c|c|c|c|c|c|c|c|c|c|c|c|c|c|}
\hline \multirow[b]{2}{*}{ Species } & \multicolumn{3}{|c|}{ 1. Classification } & \multicolumn{2}{|c|}{ 2. Forest } & \multicolumn{6}{|c|}{ Cabruca } & \multicolumn{2}{|c|}{ 3. Response } \\
\hline & ت્ّ & 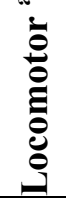 & $\stackrel{\circ}{\stackrel{*}{\sigma}}$ & 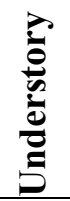 & 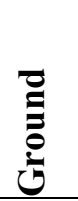 & हैं & 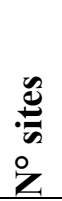 & 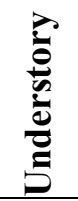 & 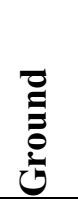 & हैं & 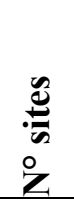 & 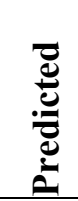 & $\begin{array}{l}\overrightarrow{0} \\
\stackrel{0}{0} \\
0 \\
0 \\
0\end{array}$ \\
\hline \multicolumn{14}{|l|}{ Order Carnivora } \\
\hline Canis familiaris & & & & 0 & 21 & 21 & 6 & 0 & 66 & 66 & 9 & $\uparrow$ & $\uparrow$ \\
\hline Felis catus & & & & 0 & 1 & 1 & 1 & 0 & 3 & 3 & 1 & $\uparrow$ & na \\
\hline \multicolumn{14}{|c|}{ Order Artiodactyla } \\
\hline Bos taurus & & & & 0 & 0 & 0 & 0 & 0 & 7 & 7 & 3 & $\uparrow$ & na \\
\hline Total non-native & & & & $\mathbf{0}$ & 22 & 22 & & $\mathbf{0}$ & 76 & 76 & & & \\
\hline
\end{tabular}

a Locomotor habits: $\mathrm{AR}=$ arboreal, $\mathrm{SC}=$ scansorial, $\mathrm{AS}=$ semi-aquatic, $\mathrm{SF}=$ semi-fossorial and $\mathrm{TE}=$ terrestrial, after Fonseca et al. $(1996) ;{ }^{\mathrm{b}}$ Diet: $\mathrm{FR}=$

frugivore and $\mathrm{CR}=$ carnivore, modified from Fonseca et al. (1996); ${ }^{\mathrm{c}}$ two species are listed in Moura (2003): M. americana and M. gouazoubira. 


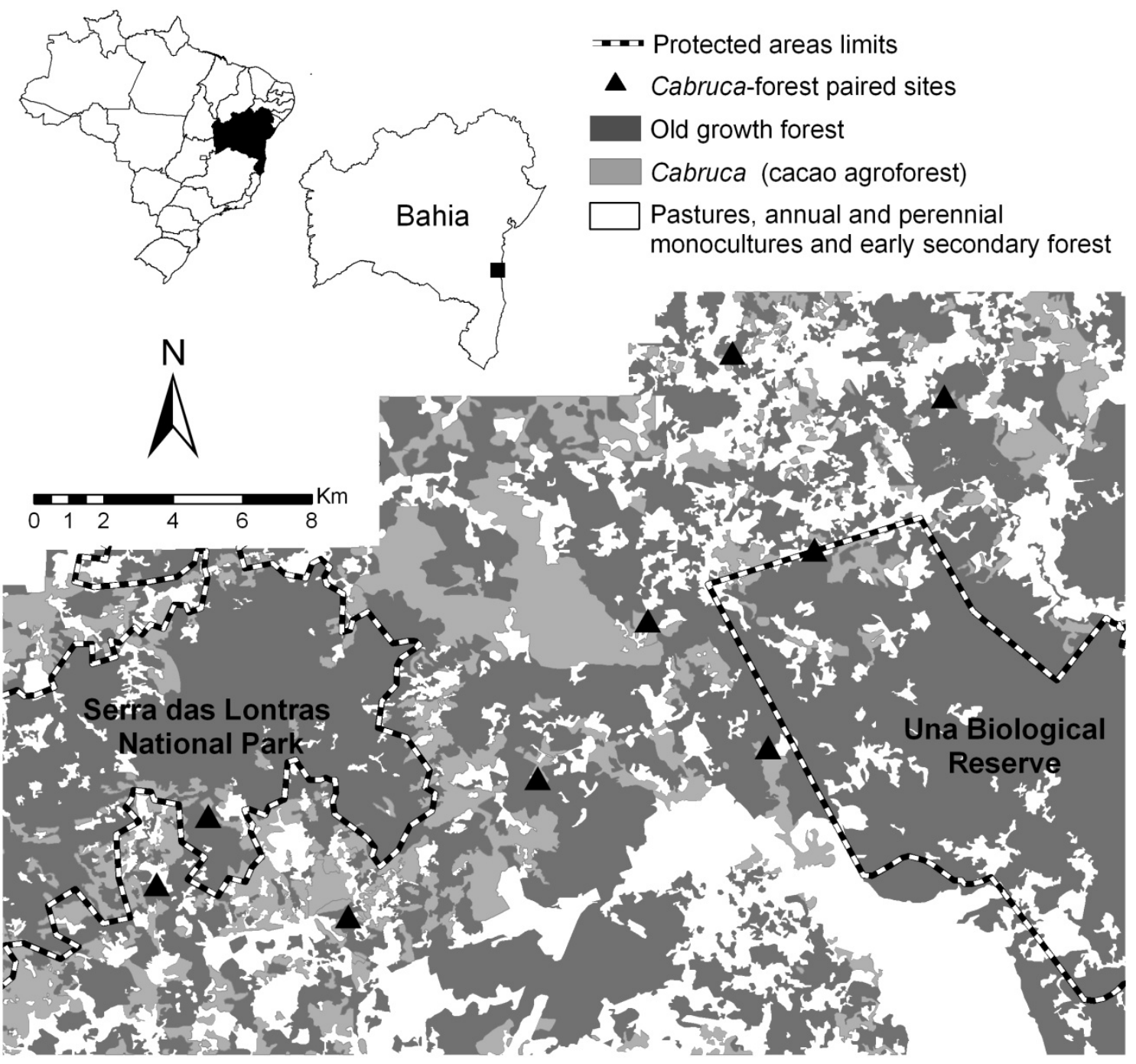

Figure 1: Map of study area, showing the location of the nine cabruca-forest sampling blocks in southern Bahia and the main land-uses. 


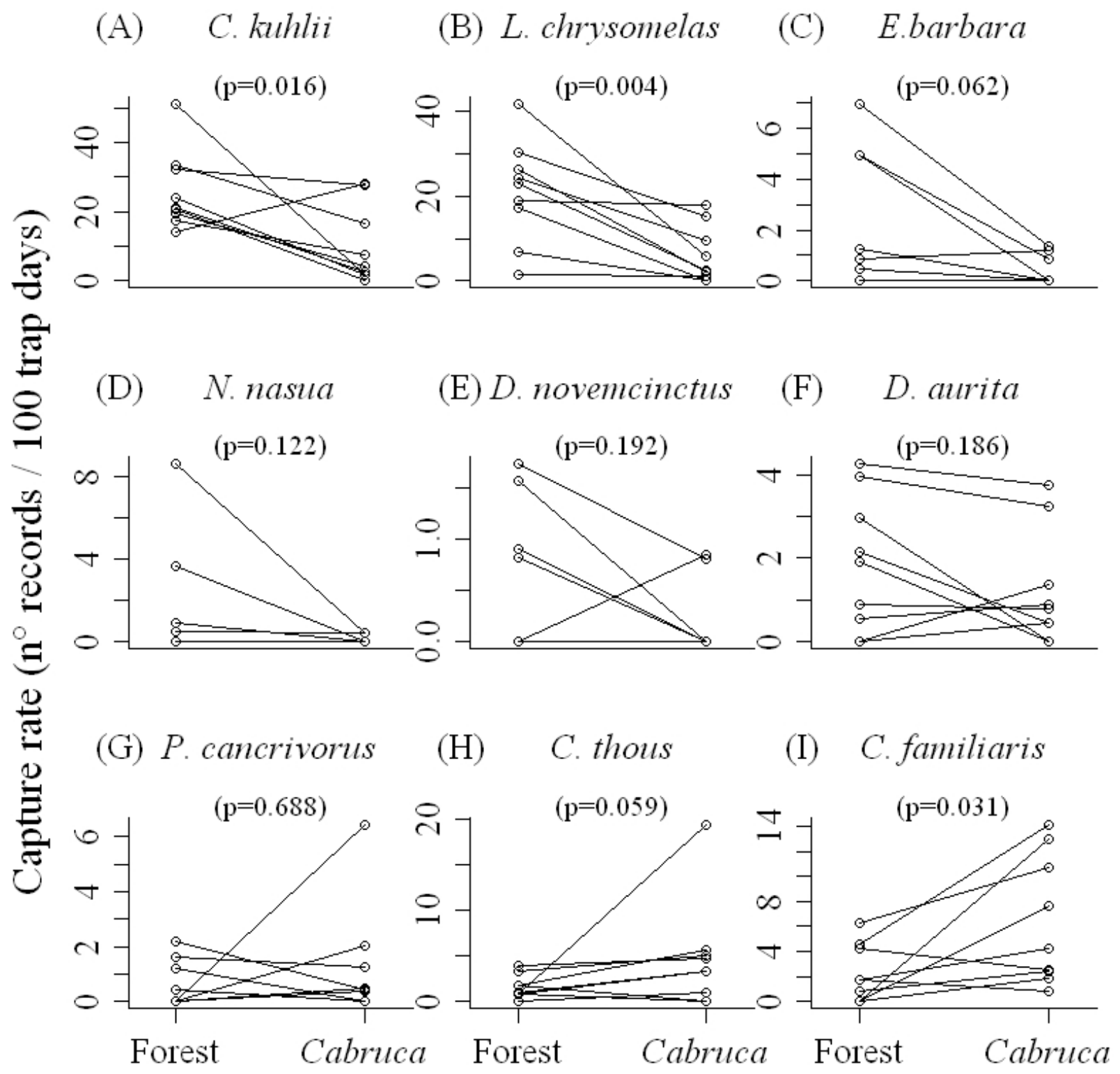

Figure 2: Capture rates of (A-H) eight native and (I) one non-native large mammal species in forest and cabruca sites. 


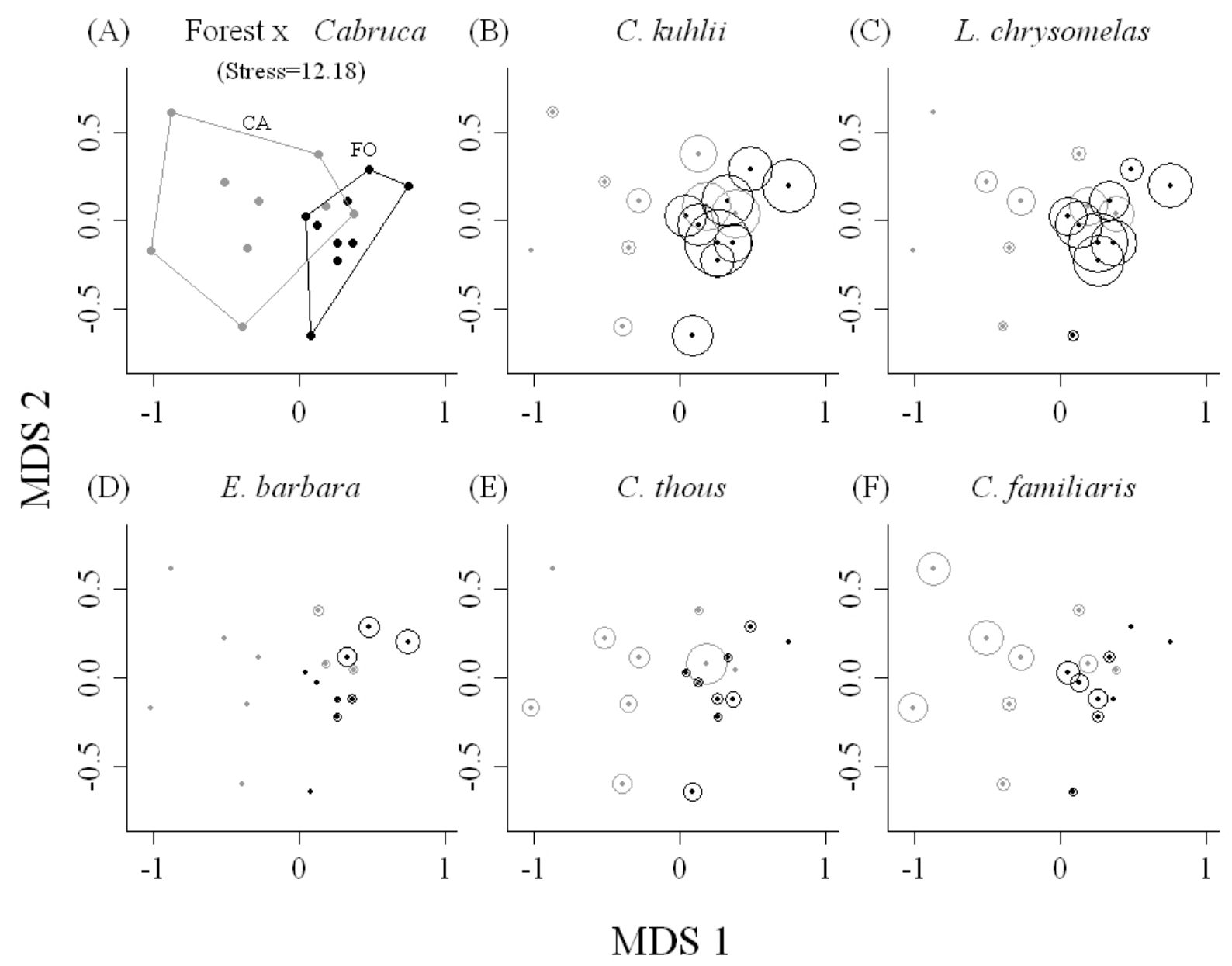

Figure 3: (A) Two-dimensional MDS plots on the similarity in assemblage structure among forest sites (FO) in black and cabruca sites (CA) in gray; (B-F) capture rates of species with significant differences between the two systems plotted over two-dimensional MDS (circle diameters are scaled according to square-root of the capture rate). 

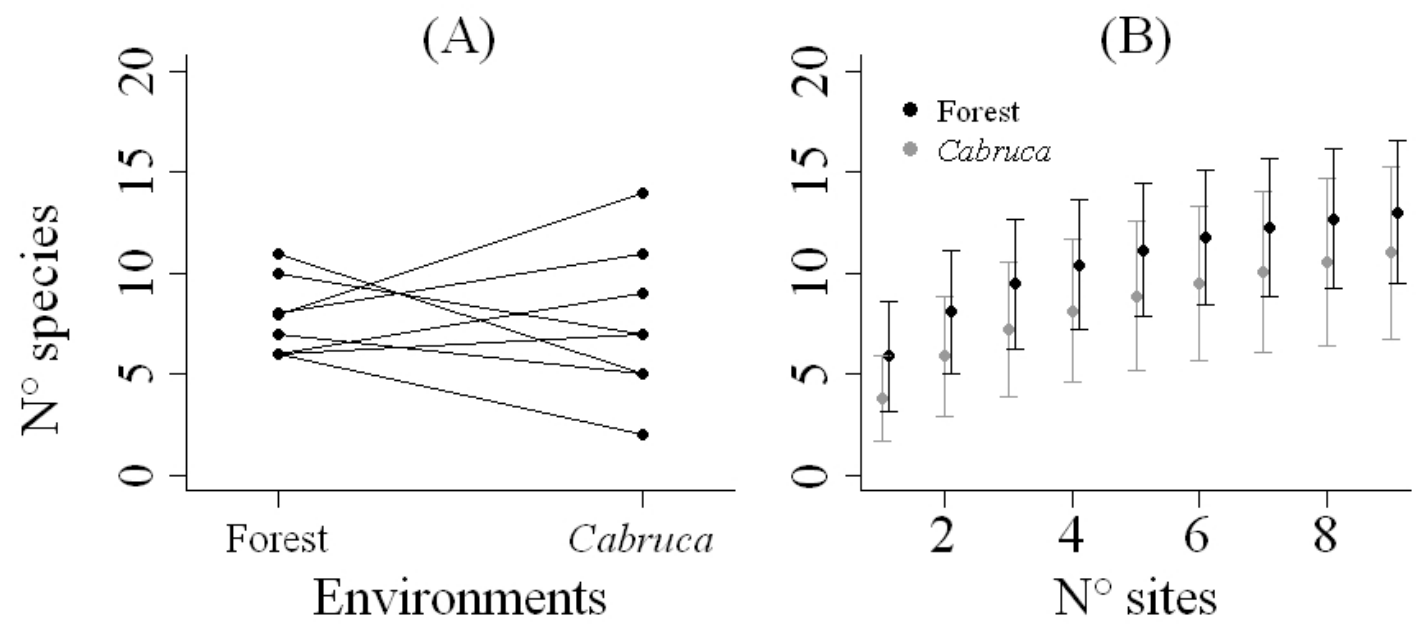

Figure 4: Comparisons of native large mammals richness in forest and cabruca sites. (A) Paired comparison of alpha diversity (based on estimated richness by Jackknife1) and (B) Comparison of gamma diversity through species accumulation curves (mean $\pm 95 \% \mathrm{CI}$ ). 


\subsection{Supporting Information}

Table S1: Results from SIMPER analysis, showing the contribution of each species for the dissimilarity in assemblage structure between cabrucas and forests.

\begin{tabular}{lcc}
\hline Species & Species contribution (\%) & Cumulated percentage \\
\hline Leontopithecus chrysomelas & 18.42 & $\mathbf{1 8 . 4 2}$ \\
Callithrix kuhlii & 18.2 & $\mathbf{3 6 . 6 2}$ \\
Canis familiaris & 10.18 & $\mathbf{4 6 . 8 0}$ \\
Cerdocyon thous & 7.60 & $\mathbf{5 4 . 3 9}$ \\
Eira barbara & 6.96 & $\mathbf{6 1 . 3 5}$ \\
Didelphis aurita & 5.48 & 66.83 \\
Cuniculus paca & 4.96 & 71.79 \\
Procyon cancrivorus & 4.92 & 76.71 \\
Nasua nasua & 4.78 & 81.49 \\
Dasypus novemcinctus & 3.27 & 84.76 \\
Bos taurus & 3.07 & 87.83 \\
Cabassous sp. & 2.69 & 90.52 \\
Potus flavus & 1.76 & 92.28 \\
Cebus xanthosternos & 1.43 & 93.71 \\
Felis catus & 1.25 & 94.96 \\
Euphractus sexcinctus & 1.13 & 96.09 \\
Mazama sp. & 1.06 & 97.14 \\
Sylvilagus brasiliensis & 0.74 & 97.89 \\
Dasyprocta aff. agouti & 0.62 & 98.5 \\
Leopardus sp. & 0.51 & 99.02 \\
Sphygurus insidiosus & 0.50 & 99.52 \\
Chaetomys subspinosus & 0.48 & 100.00 \\
\hline
\end{tabular}




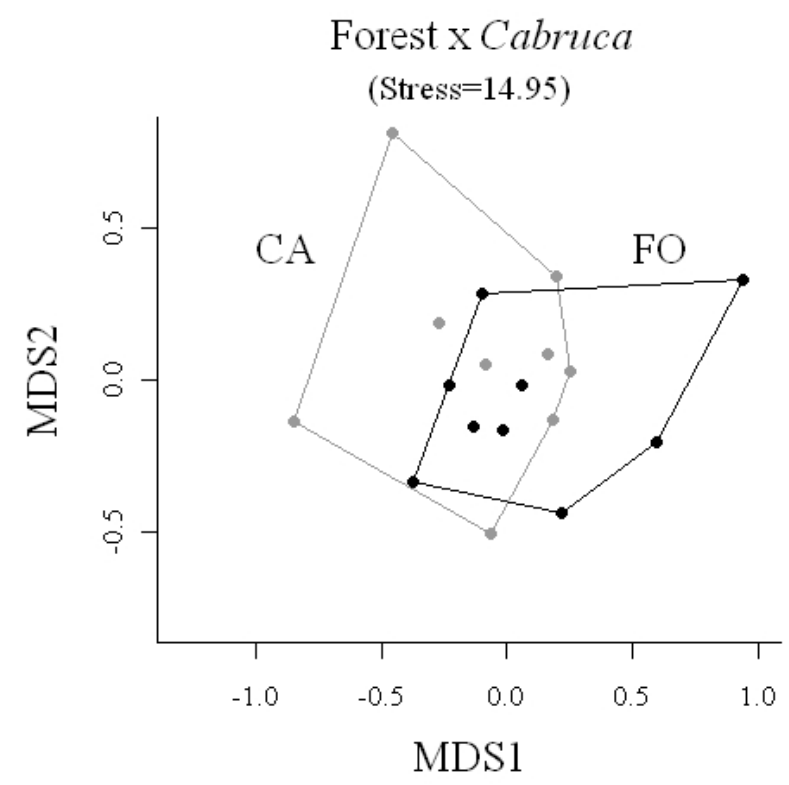

Figure S1: Two-dimensional MDS plots on the similarity in assemblage composition showing a high degree of overlap between forest sites (FO) in black and cabruca sites (CA) in gray. The ANOSIM tests did not reveal any significant differences $(R=-0.03$, $p=0.66)$. 
Forest loss or management intensification? Proximal causes of mammal decline in cacao agroforests

Camila Righetto Cassano, Jos Barlow and Renata Pardini 


\begin{abstract}
The extent and spatial configuration of native vegetation remnants, the intensification of different land-uses and the synergetic effects that result from increasing human use of landscapes exert great influence on biodiversity and associated ecosystem services. Disentangling the influence of deforestation and land-use intensification on species persistence is as important step forward in reconciling conservation and agriculture production. We studied how forest cover and management intensification affect the conservation value of cacao agroforests for mammals in an Atlantic forest landscape in southern Bahia, Brazil. Native mammal assemblages were considerably diverse in agroforests, but hunted and persecuted species were rare. Management intensification had the most important negative effects on large mammal distribution. High domestic dog capture rate, an indirect consequence of management intensification, had negative effect for several species, low canopy connectivity was negative correlated to the distribution of arboreal species and herbaceous vegetation clearance had a minor positive influence on species of non conservation concern. In highly forested regions, restricting the negative effects of land-use intensification, such as the control of domestic dog populations and overhunting, and the careful planning of shade management, is likely to bring greater benefit to native mammals in agroforests than the spatial arrangement of forest remnants. However, the importance of both shade management and remaining forest cover are likely to be higher as deforestation and intensification increase. Current scientific knowledge can already support better policy and management practices to reconcile agricultural production and biodiversity conservation in agroforestry mosaics. Best practices should be continuously adapted from further understanding of agroforestry mosaics and shade management.
\end{abstract}

Key words: Agroforestry system; domestic dog invasion; landscape management; large mammal; occupancy model; shade management 


\subsection{Introduction}

Land-use change and intensification have led to extensive modification of the Earth's ecosystems and engender great concern regarding the long term conservation of natural resources (Foley et al. 2005). An undesirable consequence of such practices is the loss of biodiversity, especially in tropical forest regions (Laurance 2007, Gardner et al. 2009). When the original vegetation is converted into alternative land-uses, patches of native vegetation are created and may become functionally isolated, negatively affecting species persistence (Fahrig 2003). While the amount and spatial configuration of the remaining native vegetation is important, population dynamics and chances of species survival in human-modified landscapes is also affected by the intensification of different land-uses (Ricketts 2001, Holzschuh et al. 2007, Fischer et al. 2011). Incorporating knowledge on how biodiversity is affected by land-use change and intensification into landscape management can enhance conservation outcomes while also meeting goals for agricultural production and improving the maintenance of crucial ecosystem services (Bennett et al. 2006, Kellermann et al. 2008, Gardner et al. 2009).

For decades studies of human-modified landscapes has been dominated by a binary classification of land as either habitat or inhospitable non-habitat, which is also known as the island-model (Lindenmayer \& Fischer 2007, Laurance 2008). This approach has allowed the identification of extremely important patterns in human-modified landscapes, such as species-area relationships (Ferraz et al. 2007), landscape habitat cover thresholds (Fahrig 2003) and interactions between habitat cover at the landscape and local (patch) scales (Andren 1994, Pardini et al. 2010). However, recognition that antropogenic environments can provide habitat for native species and influence community composition and dynamics in forest fragments (Gascon et al. 1999, Kupfer et al. 2006, Umetsu et al. 2008) has led to a growing interest in these environments (collectively known as the matrix). As a general rule, the matrix supports more diverse biological communities and provide more ecosystem services in extensive land-uses (Schulze et al. 2004, Harvey et al. 2006, Holzschuh et al. 2007) and in more forested and heterogeneous landscapes (Faria et al. 2007, Holzschuh et al. 2007). However, extensive farming uses more land than intensive farming, and the relative benefits of wildlife-friendly farming versus land-use intensification and land sparing has attracted increasing attention in recent years (Green et al. 2005, Fischer et al. 2008, Phalan et al. 2011). 
The concept of wildlife-friendly farming is epitomized by agroforestry systems, where forage or crops are cultivated in association with native or planted trees (Somarriba 1992). These systems have been viewed as an important tool for integrating socio-economic and environmental goals in tropical regions (Izac \& Sanchez 2001, Perfecto \& Vandermeer 2008). From a biodiversity conservation perspective, large areas of cacao (Theobroma cacao) and coffee (Coffea spp.) agroforests have replaced the original vegetation, but provide important habitat for native tropical forest species (Perfecto et al. 1996, Bhagwat et al. 2008, Cassano et al. 2009, Pardini et al. 2009). However, in many regions the long term conservation value of these shaded plantations is threatened by two processes: management intensification, and the loss of native vegetation from land-use change (Clough et al. 2009a, Tscharntke et al. 2011). The intensification of agroforests often involves the removal of shade trees to attain increasing crop yields, especially in cacao plantations that become less sensitive to sun with age (Tscharntke et al. 2011), what can negatively affect native species assemblages (Harvey et al. 2006, Bos et al. 2007, Harvey \& Villalobos 2007, Clough et al. 2009b). Alternatively, ongoing land-use change can impoverish native species assemblages in agroforests through decreasing forest cover in the landscape (Faria et al. 2007) and increasing isolation from forest remnants (Clough et al. 2009b).

While both deforestation and land-use intensification are important processes, often occurring simultaneously, it is important to disentangle their relative influence to effectively guide biodiversity conservation and associated ecosystems services in humanmodified mosaics. In their review, Tscharntke et al. (2005) highlight that responses to local management practices in agroecosystems are likely to differ from simple to complex landscapes, with implications relevant to agri-environmental schemes (incentives for farmers to benefit the environment). This context-dependency started to receive increasing attention in the last decade, especially regarding the contrast of organic versus conventional agriculture (e.g. Weibull et al. 2003, Rundlof \& Smith 2006, Holzschuh et al. 2007, Fischer et al. 2011). Biodiversity responses to management intensification have been the scope of several studies also in cacao and coffee agroforests. However, not only most of these studies treat management intensification as a categorical variable but also very few have simultaneously addressed the influence of native vegetation cover (e.g. Bali et al. 2007, Clough et al. 2009b). 
Here we aim to contribute to the evaluation of the relative importance of forest cover and management intensification for species distribution in agroforestry mosaics. For that we focus on southern Bahia, a region that harbors the most extensive area of diverse shaded cacao plantations in Brazil, locally known as cabrucas, with management practices that vary considerably. We examined large mammals as this group is responsible for important ecological processes in tropical forest systems (Terborgh et al. 2001, Stoner et al. 2007, Nichols et al. 2009), and include many "umbrella species" that often form the basis of conservation policies (Simberloff 1998, Roberge \& Angelstam 2004, Barua 2011). Large mammals are also vulnerable to changes in land-use (Estrada et al. 1994, Daily et al. 2003) and to the synergetic effects that result from increasing human use of landscapes, such as hunting activities (Cullen et al. 2000, Morrison et al. 2007) and the contact with domestic dog populations (Fiorello et al. 2006, Vanak \& Gompper 2009). We used camera-traps to record large mammals in 30 cabrucas, where we measured independent variables describing: (1) the amount and proximity to forest remnants; and (2) direct and indirect aspects of management intensification, represented by vegetation structure and domestic dog capture rate, respectively. We used a model selection approach (Burnham \& Anderson 2002) to evaluate alternative hypotheses regarding the relative importance of forest cover and management intensification. In addition, we examine the importance of considering camera-trap detectability by comparing selected sets of occupancy and abundance models (Royle \& Nichols 2003, Mackenzie et al. 2006), which consider imperfect detectability, to selected sets of models that do not account for this parameter.

\subsection{Materials and methods}

\section{Study area and sites}

Southern Bahia encompasses some of the largest remnants of Atlantic forest in northeastern Brazil, which are recognized for high species richness and endemism (Silva \& Casteleti 2003, Martini et al. 2007). Part of southern Bahia was once one of the main cacao growing regions in the world, with approximately $6000 \mathrm{~km}^{2}$ covered by cacao plantations, mainly grown in agroforests. In the late 1900's, Bahian cacao yield dropped as consequence of increasing losses due to witches broom fungal disease (Moniliophthora perniciosa) and the low investment that followed the decrease in the international price of cacao (Johns 1999). Since then, a slow process of conversion of the traditional cabrucas towards non-shaded or single-species shaded plantation has taken place (Johns 1999). 
Nevertheless, landscapes in the region still harbor diverse and dense shaded cabrucas mixed with different proportions of native forest (Figure 1A). Two main shade management categories of cacao plantations in the study region are the diverse cabrucas and single species (usually Hevea brasiliensis or Erythrina spp.) shaded plantations. The cabrucas are highly heterogeneous, resulting from the shade trees that were kept during their creation and the subsequent tree mortality and recruitment (Sambuichi \& Haridasan 2007). Our interest was to evaluate management intensification within these diverse shaded systems, rather than compare diverse agrofrorests with those shaded by monocultures.

This study was developed in a highly forested landscape (50\% forest cover, $15 \%$ agroforest; between $39^{\circ} 5^{\prime}-39^{\circ} 22^{\prime} \mathrm{W}$ and $15^{\circ} 4^{\prime}-15^{\circ} 14^{\prime} \mathrm{S}$; Figure $1 \mathrm{~B}$ ) in the vicinity of two protected areas: the Una Biological Reserve and the Serra das Lontras National Park (for further information on landscape features, original vegetation and climate see Cassano et al., unpublished). Sample sites were located in 30 cabrucas with different management practices and surrounding landscape contexts. Two initial criteria for site selection were: (1) cacao plantations mainly shaded by native tree species (i.e. considered a cabruca); and (2) minimal distance of $1.5 \mathrm{~km}$ between sites. We maximized the variability and minimized spatial correlation of surrounding contexts by dividing the landscape into three groups (west, central and east) and searching for sites distant to forest and near small and large forest remnants within each group.

\section{Data collection}

\section{Vegetation samples}

Vegetation was sampled in four $10 \times 25 \mathrm{~m}$ plots at each site to quantify direct consequences of management intensification. The plots were spaced every $20 \mathrm{~m}$ in an area of $25 \times 100 \mathrm{~m}$ where two trap stations were placed (see section Mammal sampling). Within each plot, we counted and measured all shade trees and banana stems $\geq 10 \mathrm{~cm}$ diameter at breast height $(\mathrm{DBH})$. We identified the most common exotic trees and classified them according to whether they produce fleshy (Annona squamosa, Artocarpus heterophyllus, Carica sp., Citrus spp., Spondias mombin) or non-fleshy fruits (Erithryna spp., Gliricidia sp. and Hevea brasiliensis). The remaining native trees were not identified. We also counted all cacao shrubs inside half of each plot $(5 \times 25 \mathrm{~m})$. We counted the number of medium and large bromeliads on tree crowns and estimated the proportion of each tree 
crown connected to adjacent trees using an index ranging from 0 to 4 , corresponding to the number of quadrants of the tree crown connected to adjacent trees. The same index was used to estimate connectivity among cacao shrubs. We measured the height of herbaceous vegetation, the tallest herbaceous plant within a $0.5 \times 0.5 \mathrm{~m}$ quadrate, at 12 points that were evenly distributed at $5 \mathrm{~m}$ intervals along one of the plot sides and along its center. We interviewed farm laborers for an estimation of the frequency of herbaceous vegetation clearance. Shade trees, banana stems and cacao trees were measured just once, at the end of the second sampling session (see section Mammal sampling). Herbaceous vegetation height, highly variable in time, was measured at the end of the second, third and fourth sampling sessions.

\section{Mammal sampling}

Two camera-traps (analog Trapacamera - www.trapacamera.com) were placed in each sampling site, one on the ground and one in the understory, following the sampling protocol described in Cassano et al. (unpublished). Data on native and non-native mammals were collected on four sampling sessions, during July-October of 2007 and 2008, and January-April of 2008 and 2009. For logistical reasons, sampling was divided into three groups of sites, each composed of 10 cabrucas that were sampled simultaneously. During each sampling session the trap stations of all 30 cabruca sites were active for four weeks and checked weekly to exchange films and re-bait. The malfunction of camera-traps and the depletion of films before the weekly check prevented equal effort among sites, sessions and stations, which was taken into account in data analysis.

\section{Data analysis}

\section{Forest cover}

We used two forest cover variables to quantify the amount and proximity of forest remnants around each cabruca site: (1) forest cover index - quantifies the area covered by native forest in the immediate vicinity of cabruca sites (400-m radius circumferences), weighted by the distance to the sites (Table 1); and (2) proximity to large forest remnants a categorical variable distinguishing, at a larger spatial scale, cabruca sites near $(\leq 800 \mathrm{~m})$ or far $(>800 \mathrm{~m})$ from the main forest remnants in the landscape (Figure 1B; see supporting information (SI) for details on forest cover index and proximity to large forest remnants 
calculations). Data were extracted from a digital land-use map provided by the Instituto de Estudos Socioambientais do Sul da Bahia, based on aerial photographs from years 1996/97 and Ikonos satellite image from 2007, using ArcGIS 9.2 (ESRI 2007).

\section{Management intensification}

In order to select appropriate metrics of management intensification, we used a principal component analysis (PCA) to ordinate sites according to the 14 variables describing vegetation structure and composition (Table 1). From this analysis, we chose two vegetation measurements that are both impacted by management intensification and have ecological meaning to animals: (1) sum of canopy connectivity index (directly related to shade management); and (2) average herbaceous vegetation height (directly related to frequency of herbaceous vegetation clearance). Increasing canopy connectivity is expected to positively influence the ability of species that move through the vegetation (arboreal and scansorial). Increasing herbaceous vegetation height is expected to influence species that move on the ground (terrestrial and scansorial) either positively, providing shelter, or negatively, decreasing prey availability.

Domestic dog capture rate, calculated as the total number of records by total sampling effort at ground trap stations (Table 1), was also inserted into the PCA, providing inference about the relationship between this variable and management intensification. We considered one record the presence of at least one picture during a 24-hour period (starting at 00:00 h ending at 24:00 h) and sampling effort was computed (in trap-days) counting only days in which there was no apparent camera-trap malfunction or film depletion. PCA was run in a correlation matrix using Package Vegan and R 2.10.1 (R Development Core Team 2009). 
Modeling large mammal distribution as a function of forest cover and management intensification

We used abundance models (Royle \& Nichols 2003) to investigate the influence of the five explanatory variables (two forest cover and three management variables) on species abundance $(\lambda)$, and single-season occupancy models (Mackenzie et al. 2006) to investigate their influence on species occupancy ( $\Psi$ ) and detectability (p). Abundance models were used for one species recorded in 29 sites, while occupancy models were used for species recorded in more than five and less than 26 sites (Table S1). The detectability from occupancy models was modeled as a function of explanatory variables only for species recorded in more than 10 sites. This parameter was modeled as a function of explanatory variables because both forest cover context and management intensification are expected to change the use of the agroforests by mammals, which can influence species detectability. Additionally, the detectability from abundance and occupancy models were modeled as a function of sampling effort, which varied between sites and sessions. We controlled for uneven sampling effort in ground and understory stations by excluding extra days from the station with the larger sampling effort before accounting for detection or non-detection of the target species in each of the four sampling sessions. We assumed that (1) changes in occupancy and abundance during the period of the study are irrelevant for the analysis owing to the slow population dynamics and the long life expectancy of large mammals; and (2) that the study design guarantees the independence of the probability of detecting a species among sites. Given the small size of the sampling sites in relation to the home range of most large mammals, we interpreted occupancy estimates as the proportion of sites used by the species (for further discussion see Mackenzie et al. 2006, p.105), assuming random movement of the target species in and out of a study site during each sampling session. The parameters $\lambda$ from abundance model and $\mathrm{p}$ from occupancy models are interpreted as a proxy of site use intensity.

We also modeled species naïve occurrence (presence/absence) and the number of records (number of trap-days the species was recorded, considering only the ground trap station for terrestrial species and both ground and understory stations for arboreal and scansorial species) using general linear models (GLMs) and mixed models (GLMMs) (Table S1; see SI for detail on GLMs and GLMMs) to investigate how detectability affects the results. Hereafter we refer to these models as naïve occurrence and record count models, and we 
use the general term distribution when referring to both where a species occurs and the intensity it uses the sampling sites.

The dependant variables $\lambda, \Psi$, p, naïve occurrence and number of records were modeled using single and multi-variable models, and one constant reference model. Multi-variable models included additive combinations of two or three explanatory variables, but never included the two forest cover variables together as these quantify the same factor. We avoided multi-variable models with higher numbers of variables or interaction terms given the limited number of sampling units. The set of candidate models differed for arboreal, scansorial and terrestrial species, because we did not include canopy connectivity in models for terrestrial species or herbaceous vegetation in models for arboreal species (Table S1).

We compared alternative models using the difference in their AICc (Akaike's Information Criterion modified for small samples; Burnham \& Anderson 2002) values in relation to the best model $(\triangle \mathrm{AICc})$. A value of $\triangle \mathrm{AICc} \leq 2$ indicates equally plausible models. We standardized all explanatory variables dividing by maximum value before running the analysis. Models that did not converge using the default optimization method, BroydenFletcher-Goldfarb-Shanno (BFGS), were optimized by the method simulated annealing (SANN; Bélisle 1992). We selected the plausible occupancy models in a three-step procedure (see SI for details). R 2.10.1 (R Development Core Team 2009) was used to run the occupancy and the abundance models (using the Unmarked package), as well as the GLMs and GLMMs.

\subsection{Results}

The final effort per site ranged from 168 to 254 trap-days, with a total sampling effort of 6592 trap-days. We obtained a total of 1694 records from 20 native and 267 records from four non-native mammals. Wied's black-tufted-ear marmoset (Callithrix kuhlii), goldenheaded lion-tamarin (Leontopithecus chrysomelas), crab-eating fox (Cerdocyon thous) and opossum (Didelphis aurita) were the most common native species, representing $89 \%$ of the records from this group (Table 2). Domestic dog (Canis familiaris) was the most frequently recorded non-native species, representing alone $88 \%$ of the records from this group. It was also the third most common species overall, and the only species recorded at all sites (Table 2). 


\section{Cabruca management}

The first axis of the PCA explained $28 \%$ of the variation in vegetation structure and domestic dog capture rate among sites. This axis represents a gradient of management intensity, with increasing values representing the replacement of canopy trees by banana stems in the shade layer, and the increase in number of cacao shrubs and in the frequency of herbaceous vegetation clearance. The canopy connectivity and the herbaceous vegetation height were both negatively correlated with this axis, while domestic dog capture rate was positively correlated (Figure S1). The second axis of the PCA explained $16 \%$ of the variation in vegetation structure and also correlates with plantation management. Values for this axis increase from cabrucas shaded by a larger number (and size) of native trees to those shaded by a larger number of exotic non-fruit trees. Canopy connectivity was negatively correlated and herbaceous vegetation height positively correlated with this axis.

\section{Large mammal distribution as a function of forest cover and management intensification}

Nine species were recorded in six or more sites and were included in the analysis. We modeled abundance and number of records for one species: C. kuhlii; occupancy, detection probability, naïve occurrence and number of records for five species: the previously mentioned C. thous, D. aurita and L. chrysomelas, plus tayra (Eira barbara) and crabeating raccoon (Procyon cancrivorus); and only occupancy and naïve occurrence for three species: naked-tailed armadillo (Cabassous sp.), paca (Cuniculus paca) and wild cat (Leopardus sp.).

Arboreal species (C. kuhlii and L. chrysomelas) responded positively to the increase in the canopy connectivity index and the decrease in domestic dog capture rate (Table 3), variables that are directly and indirectly related to management intensification, respectively. For L. chrysomelas, decrease in domestic dog capture rate had a positive effect on both occupancy and naïve occurrence. Detectability of L. chrysomelas was positively related to canopy connectivity, while number of records was positively related to both the increase in canopy connectivity and the decrease in domestic dog capture rate. Abundance models selected for C. kuhlii always contained the canopy connectivity index, either alone or together with domestic dog capture rate. For this species, the record count 
model including the domestic dog capture rate was the best model, although it was equally likely as the reference model (Table 3).

For scansorial species (D. aurita, E. barbara, Leopardus sp. and Procyon cancrivorus), the reference model was always part of the selected sets of occupancy, naïve occurrence and record count models, with the exception of naïve occurrence of Leopardus sp. (Tables 3 and S2). Naïve occurrence of this species was negatively affected by management intensification, being negatively correlated to the increase in domestic dog capture rate and decrease in herbaceous vegetation height, as well as by forest cover context, being negatively affected by the proximity to large forest remnants (Table 3). For this species, the occupancy model with the lower AICc also had occupancy negatively affected by domestic dog capture rate and an evidence weight twice as large as the reference model. Moreover, herbaceous vegetation height and proximity to large forest remnants also appeared in plausible models with the same effects described to naïve occurrence. For D.aurita, the reference model had the lower AICc, independently of the parameter modeled. The selected sets of occupancy, naïve occurrence and record count models for $E$. barbara and $P$. cancrivorus were composed by a large number of plausible models (3-8) and few occupancy models for P. cancrivorus converged when the default optimization method was used. When using the SANN optimization method, different sets of models were selected every time the models were rerun and a new model selection performed. The SANN optimization method was also used in non-convergent occupancy models for Leopardus sp., but the results from model selection did not change when models were rerun.

Responses to forest cover and management intensification differed among terrestrial species (Cabassous sp., Cuniculus paca and Cerdocyon thous). For Cabassous sp. occupancy was negatively affected by the increase in herbaceous vegetation height and domestic dog capture rate, showing opposite responses to a direct and an indirect consequence of management intensification. Occupancy of Cabassous sp. was also negatively affected by proximity to large forest remnants. The same three variables explained Cabassous sp. naïve occurrence (Table 3). For C. paca, the selected sets of occupancy and naïve occurrence models were composed of seven plausible models each, with different combinations of the same three variables, and the reference model had the lower AICc (Table S2). C. thous was negatively affected by the increase in forest cover, with occupancy and detectability negatively correlated to proximity to large forest 
remnants and forest cover index, respectively (Table 3). For this species, naïve occurrence was negatively influenced by proximity to large forest remnants and the increase in herbaceous vegetation height, while the number of records was negatively influenced by the increase in forest cover index. However, for both naïve occurrence and number of records the selected set of models included the reference model.

\subsection{Discussion}

Our results confirm that although cabrucas harbor a diverse large mammal assemblages, many important species are absent from this land-use (cf. Cassano et al. unpublished). This previous study suggests the scarcity of ungulates, large-bodied primates and rodents, and felids in the agroforestry mosaic as a consequence of overhunting and persecution, and states the need to consider this baseline when analyzing current responses to environmental variables. In the following section we briefly consider the strength and limitations of different classes of models for analyzing camera-trap data. We then discuss the relative importance of forest cover and management intensification for the use of agroforests by large mammals, place the results into the context of a highly forested although defaunated landscape, and highlight the implications of management practices for the long term conservation of native large mammals in agroforestry mosaics.

\section{Comparing models that consider or not detectability}

Results from models that consider or and models that do not consider detectability were similar regarding the variables that best explained mammal use of cabrucas, the direction of their effects, and the selection of the reference model. Thus, although occupancy estimate can be improved by models that consider imperfect detectability (Bailey et al. 2004), general responses seem to be identifiable in the absence of this parameter, at least when sampling is standardized among sites as in this study. Our results also show that detectability retains information about the intensity of use of sampling sites and that occupancy models can be improved when both $\Psi$ and $\mathrm{p}$ are modeled as a function of environmental variables. High costs and limited technical and human resources mean that many ecological studies have a limited sampling size, and the complexity of models that consider detectability might prevent model convergence, as in the case of occupancy models for crab-eating raccoon ( $P$. cancrivorus). Models based on detectability might also 
complicate the use of robust sampling designs (e.g. nested or paired designs), which can also improve the identification of significant biological patterns. While occupancy models are undoubtedly useful for analyzing camera-trap presence/absence data, our data suggests we should not discard information about the intensity of use contained in counts or rates of records, especially when robust and standardized sampling design are used. As with other statistical paradigms, there is a case for plurality, and decisions about which statistics should reflect the characteristics of the data collection protocols and the biological system that is being studied (cf. Stephens et al. 2005).

\section{Forest cover vs. management intensification}

Management intensification had the most important negative effects on large mammal distribution in cabrucas. Domestic dog capture rate, which represents an indirect effect of management intensification, affected the larger number of species while canopy connectivity affected arboreal species. Although domestic dogs are considered weak competitors, they may be important competitors and predators of native species because high population densities are subsidized by humans (Vanak \& Gompper 2009). Pathogen spillover from dogs is also a substantial threat to native fauna (Fiorello et al. 2006, Whiteman et al. 2007, Curi et al. 2010). Negative correlations between the distribution of domestic dog and native mammals have been previously detected, and this non-native species has been reported more frequently in forest edges than in interiors, in the matrix than in forest remnants, and near human settlement (Espartosa 2009, Lacerda et al. 2009, Vanak \& Gompper 2010). However, the negative effects might spread through the landscape if areas where domestic dogs occur function as a sink of individuals or if pathogens spread through native populations.

The negative influence of reduced canopy connectivity for arboreal species is especially relevant given the relatively high number of threatened and endemic species in this group (Fonseca et al. 1996, Costa et al. 2005). Habitat and inter-patch connectivity provided by agroforests are crucial for long term viability of neotropical primate populations inhabiting the study region and agroforestry landscapes elsewhere (Estrada et al. 2006, Zeigler et al. 2010). Our study confirms previous results that underline the importance of canopy pathways for arboreal species inhabiting agroforests (Estrada et al. 2006). Nevertheless, because the canopy layer in cabrucas are mainly composed of native trees, increasing canopy connectivity might also increase food availability, and arboreal species should not 
be expected to positively respond to canopy connectivity provided exclusively by exotic non-fleshy fruit trees which are common in cacao agroforests.

Management intensification had also positive effects on mammals. However, the species that positively responded to the decrease in herbaceous vegetation height has no conservation concern. Armadillos have been recorded in highly intensified agroecosystems and modified landscapes (Estrada et al. 1994, Silva \& Pontes 2008, Andrade-Nunez \& Aide 2010), and also occur in open biomes (Fonseca et al. 1996). Thus, management intensification of agroforests is likely to lead to a gradual decline in the conservation value of this system, as intensively managed areas are used by fewer species of conservation concern and are more prone to invasion by open-area generalist mammals.

On the other hand, large mammals were not limited by the spatial arrangement of forest remnants in our study. Lower amount of surrounding forest cover and increased distance to main forest remnants improved the use of agroforests especially by generalist species, but did not restrict the distribution of forest or threatened species. Our results differ from previous studies that contrasted the relative importance of forest cover and management intensification to vertebrate distribution among cacao and coffee agroforests. Distance to a main forest remnant was the most important factor and negatively affected richness and abundance of large mammals in coffee agroforests from Western Ghats mountain ranges in India (Bali et al. 2007). In Central Sulawesi cacao agroforests, forest specialist birds responded positively to forest edge proximity, but shade management also played important role for most functional groups (Clough et al. 2009b). We examine reasons for these differences in the following section.

\section{Placing results into regional context}

The responses of individual species and species assemblages to changes in local scale variables may depend on landscape context, which can influence population dynamics and species pool (Andren 1994, Tscharntke et al. 2005). For example, higher isolation from nesting habitats in homogeneous landscapes increased the effect of wheat field management on bee species richness (Holzschuh et al. 2007), while the abundance and richness of specialist small mammals increased with forest fragment size in one landscape with intermediate forest cover $(\sim 30 \%)$, but not in highly forested or deforested landscapes (Pardini et al. 2010). Given the large home range sizes and the high vagility of mammals, 
even the larger-scale variable proximity to main forest remnants do not segregate cabruca sites into broad scale contexts equivalent to the landscape variables used in these studies. Because our study region harbors approximately $65 \%$ of tree cover (forests plus agroforests), our results lie in the context of a highly forested landscape, which is likely to reduce species responses to local scale variables, such as management intensification and local-scale forest cover (Tscharntke et al. 2005, Pardini et al. 2010, Batary et al. 2011).

Few studies have evaluated the importance of local management intensification across a gradient of forest cover at broad scales, especially regarding large bodied species (Batary et al. 2011). Given the scarcity of studies, the non linearity of biological responses to environmental variation and the fact that different biological groups perceive the environment at distinct scales, generalizations regarding the relative importance of landuse change and intensification and the spatial arrangement of land-mosaics are difficult. This uncertainty complicates the debate about wildlife-friendly versus land-sparing approaches as strategies to reconcile agricultural production and conservation. As previously discussed by other authors (e.g. Green et al. 2005, Fischer et al. 2008) no single better approach is likely to exist and different balances of the two strategies should be adapted to different contexts.

Besides the amount of remaining forest at broad spatial scales, overhunting may also influence our results if hunted species are also vulnerable to the conversion of forest into cabrucas, or to the direct and indirect consequences of agroforest intensification. Moreover, responses to management intensification might also be stronger if wider ecological gradients of management intensity were considered. While we restricted our sampling to the cabrucas, we are aware that plantations shaded exclusively by rubber trees and unshaded plantations are increasing in southern Bahia (Johns 1999, Schroth et al. 2011). 


\section{Improving agroforestry mosaics for large mammals}

Our findings indicate that the spatial arrangement of forest remnants plays a minor role in determining the conservation value of cabrucas in our study system. Although the maintenance of forest cover is likely to be critically important in highly deforested landscapes, it should not be the sole target of conservation activities in highly forested landscapes. For conservation within agroforests, shade management seems to be a more important practice, as it influences the maintenance of additional habitat and increase interpatch connectivity for arboreal species. However, the viability of this practice should be analyzed cautiously. Since canopy connectivity was correlated with the number of shade trees, an intuitive way to achieve high canopy connectivity would be the maintenance of high tree densities. Nevertheless, because tree density is negatively correlated to cacao yield (Clough et al. 2011), greater benefit from shade management would be obtained from the planning of pathways and a careful selection of tree species when tree pruning or removal is necessary (Cassano et al. 2009, Clough et al. 2011).

Some management practices can improve the conservation value of agroforests and agroforestry landscapes without altering land-use type and management. Domestic dog vaccination and sterilization campaigns are frequently suggested as effective conservation practices for native mammals (Curi et al. 2010, Vanak \& Gompper 2010). In agroforestry landscapes, such practices would produce multiple benefits by increasing agroforest use and permeability and reducing edge effects on forest remnants as suggested in previous studies (e.g. Woodroffe \& Ginsberg 1998, Lacerda et al. 2009). A similar benefit is likely to be gained from the control of hunting activities, which has been suggested as an important pressure preventing the use of agroforestry landscapes by numerous species (Estrada et al. 1994, Harvey et al. 2006, Cassano et al. unpublished). Hunting activities are biased towards large-bodied species, and are known to impact species of low reproductive rate (Robinson \& Redford 1986, Jerozolimski \& Peres 2003). A mixed approach of law enforcement, awareness of regionally vulnerable species, and developing a supply of alternative sources of fresh meat, could help to reduce overhunting. 


\subsection{Conclusions}

We analyzed the proximal causes that determine the use of agroforests by large mammals, and examine the regional characteristics influencing the observed responses in order to produce more general conclusions. Our results suggest that the control of domestic dog population and hunting activities would bring great benefit to large mammal conservation in agroforestry landscapes without influencing the productivity of agroforests. In highly forested regions, the spatial arrangement of forest remnants has minor effects on mammal populations inhabiting the agroforestry mosaic, and shade improvement in agroforests should be adopted taking into account the trade-off between productivity and biodiversity conservation. Win-win situations in cacao yield and species richness have been recently reported in agroforests from Sulawesi, Indonesia (Clough et al. 2011). However, the thinning of the canopy layer, the replacement of agroforests by other land uses, and the establishment of new plantations in current forest lands remain as long term threats in cacao and coffee growing regions (Clough et al. 2009a, Schroth et al. 2011, Tscharntke et al. 2011). In this scenario of future land-use change and intensification, forest cover and shade maintenance in agroforests are likely to gain greater importance. The understanding of emergent properties from agroforestry mosaics and shade management would be improved by additional studies in different landscape and local contexts. Nevertheless, sound basis management can already be drawn from current scientific knowledge, and this information should be incorporated into policy and applied by land managers.

\section{Acknowledgments}

This paper benefited from grants from the European Union, the Brazilian Ministry of the Environment and Seeds of Change. CRC acknowledges her scholarship from FAPESP (07/54888-1), and is grateful to her field assistant, Rubens Vieira Lopes, and the owners and employees of the farms were the study was developed.

\section{References}

Andrade-Nunez, M. J., and T. M. AIDE. 2010. Effects of habitat and landscape characteristics on medium and large mammal species richness and composition in northern Uruguay. Zoologia 27: 909-917. 
ANDREN, H. 1994. Effects of habitat fragmentation on birds and mammals in landscapes with different proportions of suitable habitat - A review. Oikos 71: 355-366.

Bailey, L. L., T. R. SimOnS, and K. H. Pollock. 2004. Estimating site occupancy and species detection probability parameters for terrestrial salamanders. Ecol. Appl. 14: 692-702.

Bali, A., A. Kumar, and J. Krishnaswamy. 2007. The mammalian communities in coffee plantations around a protected area in the Western Ghats, India. Biol. Conserv. 139: 93-102.

BARUA, M. 2011. Mobilizing metaphors: The popular use of keystone, flagship and umbrella species concepts. Biodiversity Conserv. 20: 1427-1440.

Batary, P., B. Andras, D. KleiJn, and T. TscharntKe. 2011. Landscape-moderated biodiversity effects of agri-environmental management: A meta-analysis. Proceedings of the Royal Society 278: 1894-1902.

BÉLISLE, C. J. P. 1992. Convergence theorems for a class of simulated annealing algorithms on $\mathrm{R}^{\mathrm{d}}$. Journal of Applied Probability 29: 885-895.

Bennett, A. F., J. Q. Radford, and A. Haslem. 2006. Properties of land mosaics: Implications for nature conservation in agricultural environments. Biol. Conserv. 133: 250-264.

Bhagwat, S. A., K. J. Willis, H. J. B. Birks, and R. J. WhitTaker. 2008. Agroforestry: A refuge for tropical biodiversity? Trends Ecol. Evol. 23: 261-267.

Bos, M. M., I. StefFAn-DeWEnTER, and T. TsCharnTKE. 2007. The contribution of cacao agroforests to the conservation of lower canopy ant and beetle diversity in Indonesia. Biodiversity Conserv. 16: 2429-2444.

BurnhAM, K. P., and D. R. ANDERSON. 2002. Model selection and multimodel inference: A practical information - theoretic approach. Springer, New York, NY.

Cassano, C. R., G. Schroth, D. Faria, J. H. C. Delabie, and L. Bede. 2009. Landscape and farm scale management to enhance biodiversity conservation in the cocoa producing region of southern Bahia, Brazil. Biodiversity Conserv. 18: 577-603.

Clough, Y., J. Barkmann, J. Juhrbandt, M. Kessler, T. C. Wanger, A. Anshary, D. Buchori, D. Cicuzza, K. Darras, D. D. Putra, S. Erasmi, R. Pitopang, C. 
Schmidt, C. H. Schulze, D. Seidel, I. Steffan-Dewenter, K. Stenchly, S. Vidal, M. Weist, A. C. Wielgoss, and T. TscharntKe. 2011. Combining high biodiversity with high yields in tropical agroforests. Proc. Natl. Acad. Sci. USA 108: 8311-8316.

Clough, Y., H. Faust, and T. TscharntKe. 2009a. Cacao boom and bust: Sustainability of agroforests and opportunities for biodiversity conservation. Conservation Letters 2 : 197-205.

Clough, Y., D. D. Putra, R. Pitopang, and T. TscharntKe. 2009b. Local and landscape factors determine functional bird diversity in Indonesian cacao agroforestry. Biol. Conserv. 142: 1032-1041.

Costa, L. P., Y. L. R. Leite, S. L. Mendes, and A. D. Ditchfield. 2005. Mammal conservation in Brazil. Conserv. Biol. 19: 672-679.

Cullen, L., R. E. Bodmer, and C. V. PAduA. 2000. Effects of hunting in habitat fragments of the Atlantic forests, Brazil. Biol. Conserv. 95: 49-56.

Curi, N. H. D., A. S. Araujo, F. S. Campos, Z. I. P. Lobato, S. M. Gennari, M. F. V. Marvulo, J. C. R. Silva, and S. A. TAlamoni. 2010. Wild canids, domestic dogs and their pathogens in Southeast Brazil: Disease threats for canid conservation. Biodiversity Conserv. 19: 3513-3524.

Daily, G. C., G. Ceballos, J. Pacheco, G. Suzan, and A. Sanchez-Azofeifa. 2003. Countryside biogeography of neotropical mammals: Conservation opportunities in agricultural landscapes of Costa Rica. Conserv. Biol. 17: 1814-1826.

EspartosA, K. D. 2009. Mamíferos terrestres de maior porte e a invasão de cães domésticos em remanescentes de uma paisagem fragmentada de Mata Atlântica: avaliação da eficiência de métodos de amostragem e da importância de múltiplos fatores sobre a distribuição das espécies. MSc Dissertation, Universidade de São Paulo, São Paulo, SP.

ESRI. 2007. ArcGIS, the Complete Geographical Information System. Redlands, CA.

Estrada, A., R. ContesestradA, and D. Meritt. 1994. Non-flying mammals and landscape changes in the tropical rain-forest region of Los-Tuxtlas, Mexico. Ecography 17: 229-241.

Estrada, A., J. Saenz, C. A. Harvey, E. Najaro, D. Muñoz, and M. Rosales-Meda. 2006. Primates in agroecosystems: Conservation value of some agricultural practices 
in Mesoamerican landscapes. In: A. Estrada, P. A. Garber, M. S. M. Pavelka and L. Lueke (Eds.). New perspectives in the study of Mesoamerican primates: Distribution, ecology, behavior, and conservation. Springer, New York, NY, pp. 437-470.

FAHRIG, L. 2003. Effects of habitat fragmentation on biodiversity. Annual Review of Ecology Evolution and Systematics 34: 487-515.

Faria, D., M. L. B. Paciencia, M. DiXo, R. R. Laps, and J. Baumgarten. 2007. Ferns, frogs, lizards, birds and bats in forest fragments and shade cacao plantations in two contrasting landscapes in the Atlantic forest, Brazil. Biodiversity Conserv. 16: 23352357.

Ferraz, G., J. D. Nichols, J. E. Hines, P. C. Stouffer, R. O. BierregaArd, and T. E. LOVEJOY. 2007. A large-scale deforestation experiment: Effects of patch area and isolation on Amazon birds. Science 315: 238-241.

Fiorello, C. V., A. J. Noss, and S. L. DeEM. 2006. Demography, hunting ecology, and pathogen exposure of domestic dogs in the Isoso of Bolivia. Conserv. Biol. 20: 762771.

Fischer, C., C. Thies, and T. TscharntKe. 2011. Small mammals in agricultural landscapes: Opposing responses to farming practices and landscape complexity. Biol. Conserv. 144: 1130-1136.

Fischer, J., B. Brosi, G. C. Daily, P. R. Ehrlich, R. Goldman, J. Goldstein, D. B. Lindenmayer, A. D. Manning, H. A. Mooney, L. Pejchar, J. Ranganathan, and H. TALLIS. 2008. Should agricultural policies encourage land sparing or wildlifefriendly farming? Frontiers in Ecology and the Environment 6: 382-387.

Foley, J. A., R. DeFries, G. P. Asner, C. Barford, G. Bonan, S. R. Carpenter, F. S. Chapin, M. T. Coe, G. C. Daily, H. K. Gibbs, J. H. Helkowski, T. Holloway, E. A. Howard, C. J. Kucharik, C. Monfreda, J. A. Patz, I. C. Prentice, N. RAmankutTy, and P. K. SNyder. 2005. Global consequences of land use. Science 309: 570-574.

Fonseca, G. A. B., G. Herrmann, Y. L. R. Leite, R. A. Mittermeier, A. B. Rylands, and J. L. PAtton. 1996. Lista anotada dos mamíferos do Brasil. Conservation International, Washington, DC. 
Gardner, T. A., J. Barlow, R. Chazdon, R. M. Ewers, C. A. Harvey, C. A. Peres, and N. S. SoDHI. 2009. Prospects for tropical forest biodiversity in a human-modified world. Ecol. Lett. 12: 561-582.

Gascon, C., T. E. Lovejoy, R. O. Bierregaard, J. R. Malcolm, P. C. Stouffer, H. L. Vasconcelos, W. F. Laurance, B. Zimmerman, M. Tocher, and S. Borges. 1999. Matrix habitat and species richness in tropical forest remnants. Biol. Conserv. 91: 223229.

Green, R. E., S. J. Cornell, J. P. W. Scharlemann, and A. Balmford. 2005. Farming and the fate of wild nature. Science 307: 550-555.

Harvey, C. A., J. Gonzalez, and E. Somarriba. 2006. Dung beetle and terrestrial mammal diversity in forests, indigenous agroforestry systems and plantain monocultures in Talamanca, Costa Rica. Biodiversity Conserv. 15: 555-585.

Harvey, C. A., and J. A. G. Villalobos. 2007. Agroforestry systems conserve speciesrich but modified assemblages of tropical birds and bats. Biodiversity Conserv. 16: 2257-2292.

Holzschuh, A., I. StefFan-Dewenter, D. Kleijn, and T. TscharntKe. 2007. Diversity of flower-visiting bees in cereal fields: Effects of farming system, landscape composition and regional context. J. Appl. Ecol. 44: 41-49.

IZAC, A. M. N., and P. A. SANCHEZ. 2001. Towards a natural resource management paradigm for international agriculture: The example of agroforestry research. Agricultural Systems 69: 5-25.

Jerozolimski, A., and C. A. Peres. 2003. Bringing home the biggest bacon: A cross-site analysis of the structure of hunter-kill profiles in Neotropical forests. Biol. Conserv. 111: 415-425.

Johns, N. D. 1999. Conservation in Brazil's chocolate forest: The unlikely persistence of the traditional cocoa agroecosystem. Environ. Manage. 23: 31-47.

Kellermann, J. L., M. D. Johnson, A. M. Stercho, and S. C. Hackett. 2008. Ecological and economic services provided by birds on Jamaican Blue Mountain coffee farms. Conserv. Biol. 22: 1177-1185. 
Kupfer, J. A., G. P. Malanson, and S. B. Franklin. 2006. Not seeing the ocean for the islands: The mediating influence of matrix-based processes on forest fragmentation effects. Global Ecology and Biogeography 15: 8-20.

Lacerda, A. C. R., W. M. Tomas, and J. Marinho. 2009. Domestic dogs as an edge effect in the Brasília National Park, Brazil: Interactions with native mammals. Animal Conservation 12: 477-487.

LAURANCE, W. F. 2007. Have we overstated the tropical biodiversity crisis? Trends Ecol. Evol. 22: 65-70.

LAURANCE, W. F. 2008. Theory meets reality: How habitat fragmentation research has transcended island biogeographic theory. Biol. Conserv. 141: 1731-1744.

Lindenmayer, D. B., and J. Fischer. 2007. Landscape Models for Use in Studies of Landscape Change and Habitat Fragmentation. In: D. B. Lindenmayer and R. J. Hobbs (Eds.). Managing and Designing Landscapes for Conservation: Movimg from Perspectives to Principles. Blackwell Publishing Ltd, Malden, MA, pp. 35-48.

Mackenzie, D. I., J. D. Nichols, J. A. Royle, K. H. Pollock, L. L. Bailey, and J. E. HINES. 2006. Occupancy estimation and modeling: Inferring patterns and dynamics of species occurrence. Academic Press, San Diego, CA.

Martini, A. M. Z., P. Fiaschi, A. M. Amorim, and J. L. DA PAiXAO. 2007. A hot-point within a hot-spot: a high diversity site in Brazil's Atlantic Forest. Biodiversity Conserv. 16: 3111-3128.

Morrison, J. C., W. Sechrest, E. Dinerstein, D. S. Wilcove, and J. F. Lamoreux. 2007. Persistence of large mammal faunas as indicators of global human impacts. J. Mammal. 88: 1363-1380.

Nichols, E., T. A. Gardner, C. A. Peres, and S. Spector. 2009. Co-declining mammals and dung beetles: An impending ecological cascade. Oikos 118: 481-487.

Pardini, R., A. D. Bueno, T. A. Gardner, P. I. Prado, and J. P. Metzger. 2010. Beyond the fragmentation threshold hypothesis: Regime shifts in biodiversity across fragmented landscapes. Plos One 5: e13666.

Pardini, R., D. Faria, G. M. Accacio, R. R. Laps, E. Mariano-Neto, M. L. B. Paciencia, M. Dixo, and J. Baumgarten. 2009. The challenge of maintaining Atlantic forest biodiversity: A multi-taxa conservation assessment of specialist and 
generalist species in an agro-forestry mosaic in southern Bahia. Biol. Conserv. 142: 1178-1190.

Perfecto, I., R. A. Rice, R. Greenberg, and M. E. VanderVoort. 1996. Shade coffee: A disappearing refuge for biodiversity. Bioscience 46: 598-608.

Perfecto, I., and J. VAndermeer. 2008. Biodiversity conservation in tropical agroecosystems - A new conservation paradigm. Ann. N.Y. Acad. Sci. 1134: 173-200.

Phalan, B., M. Onial, A. Balmford, and R. E. Green. 2011. Reconciliating food production and biodiversity conservation: Land sharing and land sparing compared. Science 333: 1289-1291.

R Development Core Team. 2009. R: a language and environment for statistical computing. R Foundation for Statistical Computing. Viena. Available: http://www.Rproject.org. Accessed December 2009.

RiCKETTS, T. H. 2001. The matrix matters: Effective isolation in fragmented landscapes. Am. Nat. 158: 87-99.

Roberge, J. M., and P. Angelstam. 2004. Usefulness of the umbrella species concept as a conservation tool. Conserv. Biol. 18: 76-85.

ROBINSON, J. G., and K. H. REDFORD. 1986. Intrinsic rate of natural increase in Neotropical forest mammals - Relationship to phylogeny and diet. Oecologia 68: 516-520.

Royle, J. A., and J. D. Nichols. 2003. Estimating abundance from repeated presenceabsence data or point counts. Ecology 84: 777-790.

Rundlof, M., and H. G. SMITH. 2006. The effect of organic farming on butterfly diversity depends on landscape context. J. Appl. Ecol. 43: 1121-1127.

SAMBUICHI, R. H. R., and M. HARIDASAN. 2007. Recovery of species richness and conservation of native Atlantic forest trees in the cacao plantations of southern Bahia in Brazil. Biodiversity Conserv. 16: 3681-3701.

Schroth, G., D. Faria, L. Bede, S. A. Van Bael, C. R. Cassano, L. C. Oliveira, and J. H. C. Delabie. 2011. Conservation in tropical landscape mosaics: The case of the cacao landscape of southern Bahia, Brazil. Biodiversity Conserv. 20: 1635-1654.

Schulze, C. H., M. Waltert, P. J. A. Kessler, R. Pitopang, Shahabuddin, D. Veddeler, M. Muhlenberg, S. R. Gradstein, C. Leuschner, I. Steffan- 
DEWENTER, and T. TSCHARNTKE. 2004. Biodiversity indicator groups of tropical landuse systems: Comparing plants, birds, and insects. Ecol. Appl. 14: 1321-1333.

Silva, A. P., and A. R. M. PONTES. 2008. The effect of a mega-fragmentation process on large mammal assemblages in the highly-threatened Pernambuco Endemism Centre, north-eastern Brazil. Biodiversity Conserv. 17: 1455-1464.

Silva, J. M. C., and C. H. CASTEleti. 2003. Status of the biodiversity of the Atlantic forest of Brazil. In: C. Gallino-Leal and I. G. Câmara (Eds.). The Atlantic Forest of South America: biodiversity, threats, and outlookIsland. Press, Washington, DC, pp. 43-59.

SiMBERLOFF, D. 1998. Flagships, umbrellas, and keystones: Is single-species management passé in the landscape era? Biol. Conserv. 83: 247-257.

SOMARRIBA, E. 1992. Revisiting the past - An essay on agroforestry definition. Agroforestry Systems 19: 233-240.

Stephens, P. A., S. W. Buskirk, G. D. Hayward, and C. M. Del Rio. 2005. Information theory and hypothesis testing: A call for pluralism. J. Appl. Ecol. 42: 4-12.

Stoner, K. E., K. Vulinec, S. J. Wright, and C. A. Peres. 2007. Hunting and plant community dynamics in tropical forests: A synthesis and future directions. Biotropica 39: 385-392.

Terborgh, J., L. Lopez, P. Nunez, M. RaO, G. Shahabuddin, G. Orihuela, M. Riveros, R. Ascanio, G. H. Adler, T. D. Lambert, and L. Balbas. 2001. Ecological meltdown in predator-free forest fragments. Science 294: 1923-1926.

Tscharntke, T., Y. Clough, S. A. Bhagwat, D. Buchori, H. Faust, D. Hertel, D. Holscher, J. Juhrbandt, M. Kessler, I. Perfecto, C. Scherber, G. Schroth, E. VeldKAMP, and T. C. WANGER. 2011. Multifunctional shade-tree management in tropical agroforestry landscapes - A review. J. Appl. Ecol. 48: 619-629.

Tscharntke, T., A. M. Klein, A. Kruess, I. Steffan-Dewenter, and C. Thies. 2005. Landscape perspectives on agricultural intensification and biodiversity - Ecosystem service management. Ecol. Lett. 8: 857-874.

Umetsu, F., J. P. MetzGer, and R. PARDinI. 2008. Importance of estimating matrix quality for modeling species distribution in complex tropical landscapes: A test with Atlantic forest small mammals. Ecography 31: 359-370. 
VAnaK, A. T., and M. E. Gomprer. 2009. Dogs Canis familiaris as carnivores: Their role and function in intraguild competition. Mamm. Rev. 39: 265-283.

VANAK, A. T., and M. E. GOMPPER. 2010. Interference competition at the landscape level: The effect of free-ranging dogs on a native mesocarnivore. J. Appl. Ecol. 47: 12251232.

Weibull, A. C., O. Ostman, and A. Granqvist. 2003. Species richness in agroecosystems: The effect of landscape, habitat and farm management. Biodiversity Conserv. 12: 1335-1355.

Whiteman, C. W., E. R. Matushima, U. E. C. Confalonieric, M. D. C. Palha, A. D. L. DA Silva, and V. C. MonTEIRO. 2007. Human and domestic animal populations as a potential threat to wild carnivore conservation in a fragmented landscape from the Eastern Brazilian Amazon. Biol. Conserv. 138: 290-296.

WoOdroffe, R., and J. R. GinsBerG. 1998. Edge effects and the extinction of populations inside protected areas. Science 280: 2126-2128.

Zeigler, S. L., W. F. FAgan, R. DeFries, and B. E. Raboy. 2010. Identifying important forest patches for the long-term persistence of the endangered golden-headed liontamarin (Leontopithecus chrysomelas). Tropical Conservation Science 3: 63-77. 
Table 1: Minimum, mean and maximum values of forest cover index, 14 vegetation variables and domestic dog capture rate among the 30 cabruca sites. Variables in bold were used in single and multi-variable models to explain large mammal distribution among cabrucas.

\begin{tabular}{|c|c|c|c|}
\hline Variable & Min. & $\operatorname{Mean} \pm$ SD & Max. \\
\hline Forest cover index & $\mathbf{0}$ & $668 \pm 483$ & 2006 \\
\hline Sum of canopy connectivity index ${ }^{a}$ & 1.0 & $27.5 \pm 24.7$ & 119.0 \\
\hline Average ground vegetation height $(\mathrm{cm})$ & 22.0 & $69.9 \pm 31.5$ & 140.0 \\
\hline Number of native trees ${ }^{a}$ & 4 & $10.5 \pm 6.9$ & 34 \\
\hline Number of exotic non-fleshy fruit trees ${ }^{a}$ & 0 & $2.1 \pm 2.9$ & 10 \\
\hline Number of exotic fleshy fruit trees ${ }^{a}$ & 0 & $1.4 \pm 2.0$ & 8 \\
\hline Sum of basal area of native trees $\left(\mathrm{m}^{2}\right)^{\mathrm{a}}$ & 0.2 & $1.4 \pm 0.7$ & 2.7 \\
\hline Sum of basal area of exotic non-fruit trees $\left(\mathrm{m}^{2}\right)^{\mathrm{a}}$ & 0 & $0.2 \pm 0.2$ & 1.0 \\
\hline Sum of basal area of exotic fruit trees $\left(\mathrm{m}^{2}\right)^{\mathrm{a}}$ & 0 & $0.2 \pm 0.4$ & 1.7 \\
\hline Number of medium size bromeliads on tree crowns ${ }^{a}$ & 0 & $4.7 \pm 4.7$ & 19 \\
\hline Number of large size bromeliads on tree crowns ${ }^{\text {a }}$ & 0 & $4.0 \pm 5.0$ & 22 \\
\hline Number of cacao shrubs ${ }^{b}$ & 18 & $69.9 \pm 31.5$ & 140 \\
\hline Sum of cacao connectivity index ${ }^{b}$ & 24 & $87.6 \pm 28.7$ & 143 \\
\hline Number of banana stems ${ }^{\text {a }}$ & 0 & $4.0 \pm 4.2$ & 15 \\
\hline Frequency of herbaceous vegetation clearance (times/year) & 0.5 & $1.3 \pm 0.6$ & 2.5 \\
\hline Domestic dog capture rate (records/100 trap-days) & 0.8 & $7.1 \pm 6.0$ & 19.1 \\
\hline
\end{tabular}

${ }^{a}$ Variables measured in $0.1 \mathrm{ha} ;{ }^{\mathrm{b}}$ variables measured in 0.05 ha 
Table 2: Native and non-native mammals registered in 30 cabrucas. Number of records (in trap-days) in understory and ground trap stations and in total, number of detections (number of sessions with records), and number of sites where each species was recorded. Locomotor habit: $\mathrm{AR}=$ arboreal, $\mathrm{SC}=$ scansorial, and $\mathrm{TE}=$ terrestrial.

\begin{tabular}{|c|c|c|c|c|c|c|}
\hline Species & Understory & $\begin{array}{c}\text { Groun } \\
\text { d }\end{array}$ & Total & $\begin{array}{c}\mathrm{N}^{\circ} \\
\text { detection }\end{array}$ & $\begin{array}{c}\mathbf{N}^{\circ} \\
\text { sites }\end{array}$ & $\begin{array}{c}\text { Locomoto } \\
\text { r habit }\end{array}$ \\
\hline \multicolumn{7}{|l|}{ Order Didelphimorphia } \\
\hline Didelphis aurita ${ }^{\mathrm{b}}$ & 48 & 81 & 129 & 40 & 21 & $\mathrm{SC}$ \\
\hline \multicolumn{7}{|l|}{ Order Cingulata } \\
\hline Cabassous sp. ${ }^{\text {a }}$ & & 17 & 17 & 11 & 7 & $\mathrm{TE}$ \\
\hline Dasypus novemcinctus & & 5 & 5 & 5 & 5 & TE \\
\hline Euphractus sexcinctus & & 2 & 2 & 1 & 1 & $\mathrm{TE}$ \\
\hline \multicolumn{7}{|l|}{ Order Pilosa } \\
\hline Tamandua tetradactyla & & 2 & 2 & 2 & 1 & $\mathrm{SC}$ \\
\hline \multicolumn{7}{|l|}{ Order Primates } \\
\hline Callithrix kuhlii ${ }^{\mathrm{c}}$ & 626 & 191 & 817 & 81 & 29 & AR \\
\hline Cebus xanthosternos & 3 & & 3 & 2 & 1 & AR \\
\hline Leontopithecus chrysomelas ${ }^{\mathrm{b}}$ & 289 & 39 & 328 & 52 & 21 & AR \\
\hline \multicolumn{7}{|l|}{ Order Lagomorpha } \\
\hline Sylvilagus brasiliensis & & 1 & 1 & 1 & 1 & $\mathrm{TE}$ \\
\hline \multicolumn{7}{|l|}{ Order Rodentia } \\
\hline Chaetomys subspinosus & & 1 & 1 & 1 & 1 & AR \\
\hline Cuniculus paca ${ }^{\text {a }}$ & & 27 & 27 & 9 & 6 & $\mathrm{TE}$ \\
\hline Sphygurus insidiosus & 1 & & 1 & 1 & 1 & AR \\
\hline \multicolumn{7}{|l|}{ Order Carnivora } \\
\hline Cerdocyon thous ${ }^{\mathrm{b}}$ & & 226 & 226 & 54 & 25 & $\mathrm{TE}$ \\
\hline Eira Barbara ${ }^{\mathrm{b}}$ & 18 & 33 & 51 & 17 & 11 & $\mathrm{SC}$ \\
\hline Nasua nasua & 6 & 2 & 8 & 5 & 4 & $\mathrm{SC}$ \\
\hline Leopardus sp. ${ }^{\text {a }}$ & 1 & 8 & 9 & 7 & 6 & $\mathrm{SC}$ \\
\hline Potus flavus & 1 & & 1 & 1 & 1 & AR \\
\hline Procyon cancrivorus ${ }^{\mathrm{b}}$ & 4 & 59 & 63 & 29 & 19 & $\mathrm{SC}$ \\
\hline \multicolumn{7}{|l|}{ Order Artiodactyla } \\
\hline Mazama sp. & & 2 & 2 & 2 & 2 & TE \\
\hline Pecari tajacu & & 1 & 1 & 1 & 1 & $\mathrm{TE}$ \\
\hline Total native species & 997 & 697 & 1694 & & & \\
\hline \multicolumn{7}{|l|}{ Order Carnivora } \\
\hline Canis familiaris & & 235 & 235 & 72 & 30 & \\
\hline Felis catus & & 4 & 4 & 3 & 2 & \\
\hline \multicolumn{7}{|l|}{ Order Artiodactyla } \\
\hline Bos taurus & & 18 & 18 & 8 & 7 & \\
\hline \multicolumn{7}{|l|}{ Ordem Perissodactyla } \\
\hline Equus sp. & & 10 & 10 & 7 & 6 & \\
\hline Total non-native species & & 267 & 267 & & & \\
\hline
\end{tabular}


Table 3: Selected models $(\triangle \mathrm{AICc} \leq 2)$ describing the variation in the use of 30 cabruca sites by large mammals as a function of forest cover, management intensification, and sampling effort. Only shown results of species if the reference model was not included among the selected models for at least one model class analyzed. For the remaining species see Table S2. Dependant variables: $\lambda=$ abundance, $\Psi=$ occupancy, $p=$ detection probability, occ $=$ naïve occurrence and $\mathrm{rec}=$ number of records. Explanatory variables: fo $=$ forest cover index; prox $=$ proximity to large forest remnants; can = canopy connectivity index; herb = herbaceous vegetation height; $\operatorname{dog}=$ domestic dog capture rate; eff $=$ sampling effort. The notation (.) stands for constant.

\begin{tabular}{|c|c|c|c|c|c|c|c|c|c|c|}
\hline \multirow[b]{2}{*}{ Species } & \multirow[b]{2}{*}{ Model description } & \multirow[b]{2}{*}{ Model class } & \multirow[b]{2}{*}{ AICc } & \multirow[b]{2}{*}{$\triangle \mathrm{AICc}$} & \multirow[b]{2}{*}{$\mathbf{w}$} & Forest cover & \multicolumn{3}{|c|}{ Management intensification } & \multirow[b]{2}{*}{ eff } \\
\hline & & & & & & prox & can & herb & $\operatorname{dog}$ & \\
\hline \multirow[t]{6}{*}{ Callithrix kuhlii } & $\lambda($ can $) ; p()$. & abundance & 144.95 & 0.00 & 0.28 & & 1.77 & & & \\
\hline & $\lambda(\operatorname{can}+\operatorname{dog}) ; p()$. & & 146.90 & 1.96 & 0.11 & & 1.40 & & -0.57 & \\
\hline & $\operatorname{rec}(\operatorname{dog})$ & count & 306.46 & 0.00 & 0.23 & & & & -1.57 & \\
\hline & $\operatorname{rec}()$. & & 307.35 & 0.89 & 0.15 & & & & & \\
\hline & $\operatorname{rec}(\mathrm{fo}+\mathrm{dog})$ & & 307.39 & 0.93 & 0.14 & -1.49 & & & -1.45 & \\
\hline & rec (fo) & & 307.72 & 1.26 & 0.12 & -1.68 & & & & \\
\hline \multirow{5}{*}{$\begin{array}{l}\text { Leontopithecus } \\
\text { chrysomelas }\end{array}$} & $\Psi(\operatorname{dog}) ; p(\operatorname{can})$ & occupancy & 144.33 & 0.00 & 0.34 & & 4.09 & & -2.95 & \\
\hline & $\Psi(.) ; \mathrm{p}(\mathrm{can})$ & & 145.88 & 1.56 & 0.16 & & 4.36 & & & \\
\hline & occ (dog) & naïve occurence & 36.26 & 0.00 & 0.28 & & & & -2.88 & \\
\hline & $\operatorname{rec}(\mathrm{dog})$ & count & 186.62 & 0.00 & 0.40 & & & & -3.43 & \\
\hline & $\operatorname{rec}(\operatorname{can}+\mathrm{dog})$ & & 188.39 & 1.77 & 0.16 & & 2.03 & & -2.97 & \\
\hline
\end{tabular}


Table 3 (cont.)

\begin{tabular}{|c|c|c|c|c|c|c|c|c|c|c|c|}
\hline \multirow[b]{2}{*}{ Species } & \multirow[b]{2}{*}{ Model description } & \multirow[b]{2}{*}{ Model class } & \multirow[b]{2}{*}{ AICc } & \multirow[b]{2}{*}{$\triangle \mathrm{AICc}$} & \multirow[b]{2}{*}{$\mathbf{w}$} & \multicolumn{2}{|c|}{ Forest cover } & \multicolumn{3}{|c|}{ Management intensification } & \multirow[b]{2}{*}{ eff } \\
\hline & & & & & & fo & prox & can & herb & $\operatorname{dog}$ & \\
\hline \multirow[t]{9}{*}{ Leopardus sp. } & $\Psi(\operatorname{dog}) ; \mathrm{p}()$. & occupancy & 52.67 & 0.00 & 0.13 & & & & & -5.85 & \\
\hline & $\Psi($ prox + dog $) ; p()$. & & 53.71 & 1.04 & 0.08 & & -1.86 & & & -6.95 & \\
\hline & $\Psi($ fo + dog $) ; p()$. & & 53.83 & 1.16 & 0.08 & -12.56 & & & & -16.00 & \\
\hline & $\Psi($ dog+herb $) ; p()$. & & 54.26 & 1.59 & 0.06 & & & & 13.58 & -9.38 & \\
\hline & $\Psi($ herb); $\mathrm{p}()$. & & 54.27 & 1.60 & 0.06 & & & & 16.91 & & \\
\hline & $\Psi(.) ; \mathrm{p}()$. & & 54.45 & 1.78 & 0.06 & & & & & & \\
\hline & occ (dog) & naïve occurence & 27.03 & 0.00 & 0.15 & & & & & -5.71 & \\
\hline & occ $(\operatorname{prox}+\operatorname{dog})$ & & 27.90 & 0.87 & 0.09 & & -1.49 & & & -6.46 & \\
\hline & occ (prox + dog + herb) & & 28.96 & 1.92 & 0.06 & & -2.55 & & 4.38 & -5.67 & \\
\hline \multirow[t]{7}{*}{ Cerdocyon thous } & $\Psi(.) ; p($ fo $)$ & occupancy & 162.56 & 0.00 & 0.22 & -2.04 & & & & & \\
\hline & $\Psi($ prox $) ; p($ fo $)$ & & 163.08 & 0.52 & 0.17 & -2.33 & -5.36 & & & & \\
\hline & $\operatorname{occ}()$. & naïve occurence & 29.18 & 0.00 & 0.23 & & & & & & \\
\hline & occ (prox) & & 30.50 & 1.32 & 0.12 & & -0.98 & & & & \\
\hline & occ (herb) & & 30.81 & 1.63 & 0.10 & & & & -1.76 & & \\
\hline & rec (fo) & count & 189.15 & 0.00 & 0.30 & -1.69 & & & & & \\
\hline & $\operatorname{rec}()$. & & 189.88 & 0.73 & 0.21 & & & & & & \\
\hline \multirow[t]{5}{*}{ Cabassous sp. } & $\Psi($ prox + herb); p(eff) & occupancy & 60.25 & 0.00 & 0.32 & & -34.59 & & -89.59 & & 17.40 \\
\hline & $\Psi($ prox + herb $) ; p()$. & & 60.61 & 0.36 & 0.27 & & -12.52 & & -18.10 & & \\
\hline & $\Psi($ prox + dog + herb $) ; p()$. & & 61.07 & 0.82 & 0.22 & & -16.02 & & -34.87 & -8.05 & \\
\hline & occ (prox+herb) & naïve occurence & 22.82 & 0.00 & 0.47 & & -20.12 & & -12.80 & & \\
\hline & occ (prox + dog + herb) & & 24.51 & 1.69 & 0.20 & & -20.65 & & -16.25 & -2.31 & \\
\hline
\end{tabular}




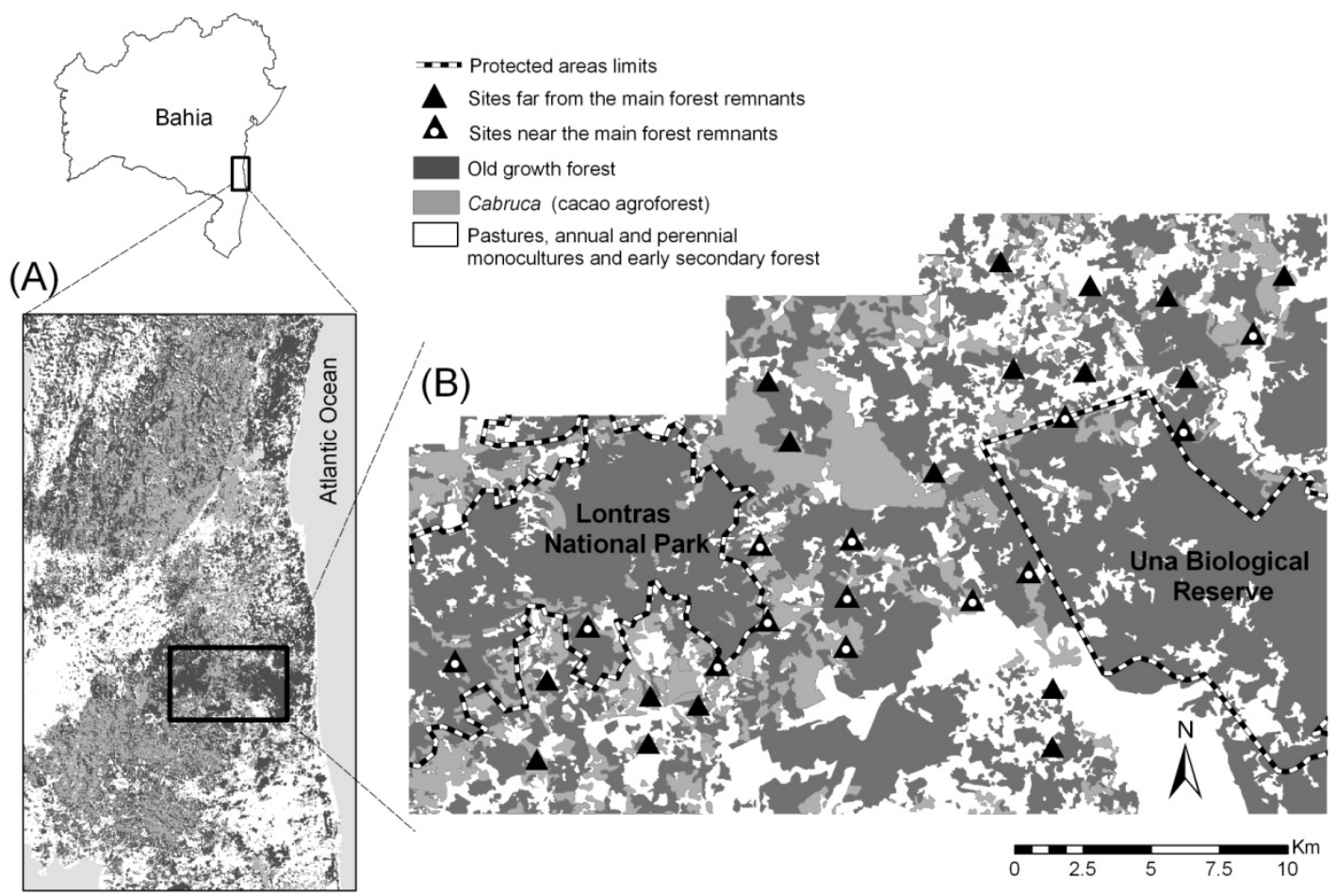

Figure 1: Land-use map of (A) the cacao growing region of southern Bahia and (B) the study region with the location of the study sites near and far from the main forest remnants. 


\subsection{Supporting Information}

\section{Calculation of forest cover variables}

Forest cover index: To calculate the forest cover index we used the location of each sampling site as central reference to define circumferences of $400 \mathrm{~m}$ radius. We clipped the circumferences from the digital land-use map, divided them into $10 \mathrm{~m}$ rings and calculated the amount of forest cover in each ring. Then, we divided the total forest cover within each ring by the average ring distance to the central site and added the 40 values. This procedure gives higher weight to forests near the study site, which are expected to be more important to define the use of the cabruca sites by mammals. We chose buffers of $400 \mathrm{~m}$ radius over buffers of 800 and $1200 \mathrm{~m}$ radius because variability in the amount of forest cover was greater at this scale.

Proximity to large forest remnants: We classified sites as near and far from the main forest remnants if the interior of these remnants were, respectively, included or not in a buffer of $800 \mathrm{~m}$ radius around the study site. We defined the main forest remnants as those with forest interior (i.e. area at least $100 \mathrm{~m}$ from the edge) larger than 500 ha. This definition of the main forest remnants included those forest patches that are expected to be most important for the populations of most recorded mammals at the study landscape. Remnants of 700 ha were estimated as the minimal patch size to support viable populations of Leontopithecus chrysomelas (Zeigler et al. 2010), which is the best studied mammal species from our landscape.

\section{Naïve occurrence and count models}

We used generalized linear models (GLMs) and mixed models (GLMMs) to model the naïve occurrence (presence/absence) and number of records (number of trap-days the species was recorded) of native mammals in cabrucas. We modeled species naïve occurrence using binomial (logit link) GLMs. We controlled for uneven sampling effort on ground and understory stations by excluding extra days from the station with the larger sampling effort before accounting for presence or absence. To control for uneven sampling effort between sites we used it as an explanatory variable and constructed models with and without this variable. We modeled number of records of terrestrial species using negative binomial (log link) GLMs and controlled for uneven sampling effort between sites using its logarithm as an offset argument in the models. For scansorial and arboreal species we 
modeled the number of successful recordings (number of records) and failed recordings (number of days the species was not recorded) by trap station strata using quasi-binomial (logit link) GLMMs. In these last models, we informed the study site and trap station strata (ground and understory) as random effect variables. Because the sampling effort corresponds to the sum of successful and failed recordings, we did not include it as an explanatory variable nor as an off-set argument. Negative binomial and quasi-binomial distributions were used to account for overdispersion in our count data.

\section{Three-step procedure used to select occupancy models}

We used a three-step procedure to select occupancy models with the variables that best explain the parameters occupancy $(\Psi)$ and detection probability (p). First, we held the proportion of occupied sites constant, $\Psi($.$) , and allowed detection probability to vary,$ $\mathrm{p}$ (var), according to single and multi-variable models. Secondly, we held species detection probability constant, $\mathrm{p}($.$) , and modeled occupancy as function of the variables, \Psi(\mathrm{var})$. For both steps we used a constant model, $\Psi(.) \mathrm{p}($.$) , as reference. At each step models were$ ranked according to Akaike's Information Criterion modified for small samples (AICc; Burnham \& Anderson 2002) and values of $\triangle \mathrm{AICc} \leq 2$ indicated equally plausible models. In a third step, the plausible $\Psi(.) \mathrm{p}(\mathrm{var})$ and $\Psi(\operatorname{var}) \mathrm{p}($.$) models for each species were$ combined in $\Psi$ (var) $\mathrm{p}$ (var) models to explore if including covariates in both parameters improved model performance. 
Table S1: Number of candidate occupancy, abundance, naïve occurrence and count models, describing the variables included depending on species locomotor habit $(\mathrm{AR}=$ arboreal; $\mathrm{SC}=$ scansorial and $\mathrm{TE}=$ terrestrial). At the bottom, the number of candidate models ran for each species is shown. In parentheses, the number of occupancy models included in the third step of occupancy model selection (see "Three-step procedure used to select occupancy models" in SI for details).

\begin{tabular}{|c|c|c|c|c|c|c|c|c|c|c|c|}
\hline \multirow{2}{*}{$\begin{array}{c}\mathrm{N}^{\circ} \\
\text { variables }\end{array}$} & \multirow[b]{2}{*}{ Variables included } & \multicolumn{3}{|c|}{ Occupancy } & \multirow{2}{*}{$\begin{array}{c}\text { Abundance } \\
\text { AR }\end{array}$} & \multicolumn{3}{|c|}{ Naïve occurrence } & \multicolumn{3}{|c|}{ Count } \\
\hline & & $\mathbf{A R}$ & SC & TE & & $\mathbf{A R}$ & $\mathbf{S C}$ & TE & $\mathbf{A R}$ & SC & TE \\
\hline 0 & & $1^{\mathrm{a}, \mathrm{b}}$ & $1^{\mathrm{a}, \mathrm{b}, \mathrm{c}}$ & $1^{\mathrm{a}, \mathrm{b}, \mathrm{c}}$ & 1 & 1 & 1 & 1 & 1 & 1 & 1 \\
\hline 1 & One forest cover or one management variable & $4^{\mathrm{a}, \mathrm{b}}$ & $5^{\mathrm{a}, \mathrm{b}}$ & $4^{\mathrm{a}, \mathrm{b}}$ & 4 & 4 & 5 & 4 & 4 & 5 & 4 \\
\hline 2 & $\begin{array}{l}\text { Combination of: } \\
\text { - one forest cover and one management } \\
\text { - two management variables }\end{array}$ & $5^{\mathrm{a}, \mathrm{b}}$ & $9^{\mathrm{a}, \mathrm{b}}$ & $5^{\mathrm{a}, \mathrm{b}}$ & 5 & 5 & 9 & 5 & 5 & 9 & 5 \\
\hline 3 & $\begin{array}{l}\text { Combination of: } \\
\text { - one forest cover and two management } \\
\text { - tree management variables }\end{array}$ & $2^{a, b}$ & $7^{\mathrm{a}, \mathrm{b}}$ & $2^{\mathrm{a}, \mathrm{b}}$ & 2 & 2 & 7 & 2 & 2 & 7 & 2 \\
\hline 1 & Sampling effort & $1^{\mathrm{b}}$ & $1^{\mathrm{b}, \mathrm{c}}$ & $1^{\mathrm{b}, \mathrm{c}}$ & 1 & 1 & 1 & 1 & & & \\
\hline 2 & $\begin{array}{l}\text { Sampling effort plus: } \\
\text { - one forest cover variable } \\
\text { - one management variable }\end{array}$ & $4^{b}$ & $5^{b}$ & $4^{b}$ & 4 & 4 & 5 & 4 & & & \\
\hline 3 & $\begin{array}{l}\text { Sampling effort plus: } \\
\text { - one forest cover and one management } \\
\text { - two management variable }\end{array}$ & $5^{b}$ & $9^{b}$ & $5^{b}$ & 5 & 5 & 9 & 5 & & & \\
\hline
\end{tabular}


Table S1 (cont.)

\begin{tabular}{|c|c|c|c|c|c|c|c|c|c|c|}
\hline \multirow[b]{2}{*}{ Species } & \multicolumn{3}{|c|}{ Occupancy } & \multirow{2}{*}{$\begin{array}{c}\text { Abundance } \\
\mathbf{A R}\end{array}$} & \multicolumn{3}{|c|}{ Naïve occurrence } & \multicolumn{3}{|c|}{ Count } \\
\hline & $\mathbf{A R}$ & SC & TE & & $\mathbf{A R}$ & SC & TE & $\mathbf{A R}$ & SC & TE \\
\hline Callithrix kuhlii & & & & 22 & & & & 12 & & \\
\hline Leontopithecus chrysomelas & $33(3)$ & & & & 22 & & & 12 & & \\
\hline Didelphis aurita & & $58(0)$ & & & & 37 & & & 22 & \\
\hline Eira barbara & & $58(16)$ & & & & 37 & & & 22 & \\
\hline Leopardus sp. & & $23(6)$ & & & & & & & 22 & \\
\hline Procyon cancrivorus & & $58(\mathrm{na})$ & & & & 37 & & & 22 & \\
\hline Cabassous sp. & & & $13(2)$ & & & & & & & 12 \\
\hline Cuniculus paca & & & $13(3)$ & & & & & & & 12 \\
\hline Cerdocyon thous & & & $33(2)$ & & & & 22 & & & 12 \\
\hline
\end{tabular}

$\Xi \quad \bar{a}$ Models run in the first step of occupancy model selection; ${ }^{b}$ models run in the second step of occupancy model selection for species recorded in 10 sites or more; ${ }^{c}$ models run in the second step of occupancy model selection for species recorded in less than10 sites (see "Three-step procedure used to select occupancy models" in SI for details). 
Table S2: Selected models ( $\triangle \mathrm{AICc} \leq 2)$ describing the variation in the use of 30 cabruca sites by large mammals as a function of forest cover, management intensification, and sampling effort. Only shown results of species if the reference model was included among the selected models. For the remaining species see Table 3. Dependant variables: $\lambda=$ abundance, $\Psi=$ occupancy, $p=$ detection probability, occ $=$ naïve occurrence and $\mathrm{rec}=$ number of records. Explanatory variables: fo $=$ forest cover index; prox $=$ proximity to large forest remnants; can $=$ canopy connectivity index; herb = herbaceous vegetation height; dog = domestic dog capture rate; eff = sampling effort. The notation (.) stands for constant.

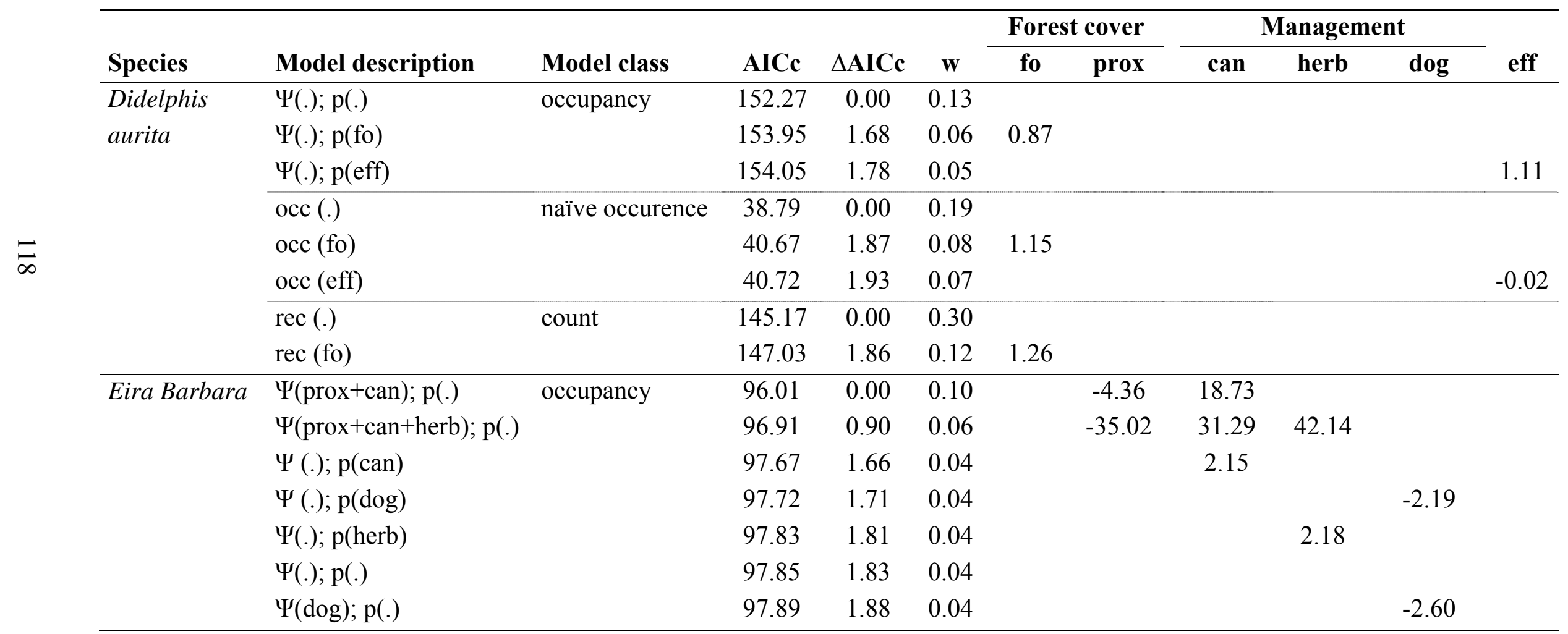


Table S2 (cont.)

\begin{tabular}{|c|c|c|c|c|c|c|c|c|c|c|c|}
\hline \multirow[b]{2}{*}{ Species } & \multirow[b]{2}{*}{ Model description } & \multirow[b]{2}{*}{ Model class } & \multirow[b]{2}{*}{ AICc } & \multirow[b]{2}{*}{$\Delta \mathrm{AICc}$} & \multirow[b]{2}{*}{$\mathbf{w}$} & \multicolumn{2}{|c|}{ Forest cover } & \multicolumn{3}{|c|}{ Management } & \multirow[b]{2}{*}{ eff } \\
\hline & & & & & & fo & prox & can & herb & $\operatorname{dog}$ & \\
\hline \multirow[t]{11}{*}{ Eira Barbara } & occ (dog) & naïve occurence & 41.43 & 0.00 & 0.10 & & & & & -2.13 & \\
\hline & $\operatorname{occ}()$. & & 41.57 & 0.14 & 0.09 & & & & & & \\
\hline & occ (prox + can $)$ & & 42.29 & 0.86 & 0.07 & & -1.45 & 3.53 & & & \\
\hline & occ (can) & & 42.36 & 0.93 & 0.06 & & & 2.32 & & & \\
\hline & occ $($ prox $+\operatorname{dog})$ & & 42.44 & 1.02 & 0.06 & & -1.01 & & & -2.33 & \\
\hline & occ (prox) & & 42.67 & 1.24 & 0.05 & & -0.88 & & & & \\
\hline & occ $(\operatorname{can}+\operatorname{dog})$ & & 43.17 & 1.75 & 0.04 & & & 1.71 & & -1.83 & \\
\hline & $\operatorname{occ}($ prox $+\operatorname{dog}+$ can $)$ & & 43.39 & 1.96 & 0.04 & & -1.45 & 2.89 & & -1.88 & \\
\hline & $\operatorname{rec}()$. & count & 100.15 & 0.00 & 0.19 & & & & & & \\
\hline & $\operatorname{rec}(\operatorname{dog})$ & & 100.31 & 0.16 & 0.18 & & & & & -2.84 & \\
\hline & rec (can) & & 101.47 & 1.32 & 0.10 & & & 2.77 & & & \\
\hline \multirow{12}{*}{$\begin{array}{l}\text { Procyon } \\
\text { cancrivorus }\end{array}$} & & occupancy & & & & & & & o sing & result & \\
\hline & occ (dog) & naïve occurence & 42.27 & 0.00 & 0.09 & & & & & -1.97 & \\
\hline & occ (can) & & 42.46 & 0.19 & 0.08 & & & 3.52 & & & \\
\hline & occ (.) & & 42.52 & 0.25 & 0.08 & & & & & & \\
\hline & occ (fo) & & 42.94 & 0.67 & 0.07 & -2.23 & & & & & \\
\hline & occ $($ fo + dog $)$ & & 43.15 & 0.88 & 0.06 & -2.23 & & & & -1.93 & \\
\hline & occ $(\operatorname{can}+\operatorname{dog})$ & & 43.29 & 1.02 & 0.05 & & & 2.96 & & -1.64 & \\
\hline & occ (fo+can) & & 43.63 & 1.36 & 0.05 & -1.93 & & 3.06 & & & \\
\hline & rec (dog) & count & 95.70 & 0.00 & 0.24 & & & & & -1.94 & \\
\hline & $\operatorname{rec}()$. & & 96.96 & 1.26 & 0.13 & & & & & & \\
\hline & rec (dog+herb) & & 97.45 & 1.75 & 0.10 & & & & -1.50 & -2.12 & \\
\hline & rec $($ prox $+\operatorname{dog})$ & & 97.66 & 1.96 & 0.09 & & -0.60 & & & -1.94 & \\
\hline
\end{tabular}


Table S2 (cont.)

\begin{tabular}{|c|c|c|c|c|c|c|c|c|c|c|c|}
\hline \multirow[b]{2}{*}{ Species } & \multirow[b]{2}{*}{ Model description } & \multirow[b]{2}{*}{ Model class } & \multirow[b]{2}{*}{ AICc } & \multirow[b]{2}{*}{$\triangle \mathrm{AICc}$} & \multirow[b]{2}{*}{$\mathbf{w}$} & \multicolumn{2}{|c|}{ Forest cover } & \multicolumn{3}{|c|}{ Management } & \multirow[b]{2}{*}{ eff } \\
\hline & & & & & & fo & prox & can & herb & $\operatorname{dog}$ & \\
\hline \multirow[t]{14}{*}{ Cuniculus paca } & $\Psi(.) ; \mathrm{p}()$. & occupancy & 63.40 & 0.00 & 0.16 & & & & & & \\
\hline & $\Psi(.) ; \mathrm{p}(\mathrm{eff})$ & & 63.79 & 0.39 & 0.13 & & & & & & 18.42 \\
\hline & $\Psi(\mathrm{fo}) ; \mathrm{p}()$. & & 64.11 & 0.71 & 0.11 & 2.70 & & & & & \\
\hline & $\Psi($ herb $) ; \mathrm{p}()$. & & 64.66 & 1.27 & 0.09 & & & & 2.83 & & \\
\hline & $\Psi($ fo $) ; p($ eff $)$ & & 64.72 & 1.32 & 0.08 & 2.74 & & & & & 18.93 \\
\hline & $\Psi($ herb $) ; \mathrm{p}(\mathrm{eff})$ & & 64.97 & 1.57 & 0.07 & & & & 3.34 & & 19.97 \\
\hline & $\Psi($ fo+herb $) ; \mathrm{p}()$. & & 65.26 & 1.86 & 0.06 & 3.68 & & & 3.97 & & \\
\hline & $\operatorname{occ}()$. & naïve occurence & 32.17 & 0.00 & 0.16 & & & & & & \\
\hline & $\operatorname{occ}($ fo) & & 32.51 & 0.35 & 0.14 & 2.63 & & & & & \\
\hline & occ (herb) & & 33.35 & 1.18 & 0.09 & & & & 2.13 & & \\
\hline & occ (fo+herb) & & 33.86 & 1.70 & 0.07 & 2.53 & & & 2.33 & & \\
\hline & occ (eff) & & 33.94 & 1.78 & 0.07 & & & & & & 0.03 \\
\hline & occ $(\operatorname{dog})$ & & 34.11 & 1.94 & 0.06 & & & & & 0.86 & \\
\hline & occ (prox) & & 34.16 & 1.99 & 0.06 & & 0.51 & & & & \\
\hline
\end{tabular}




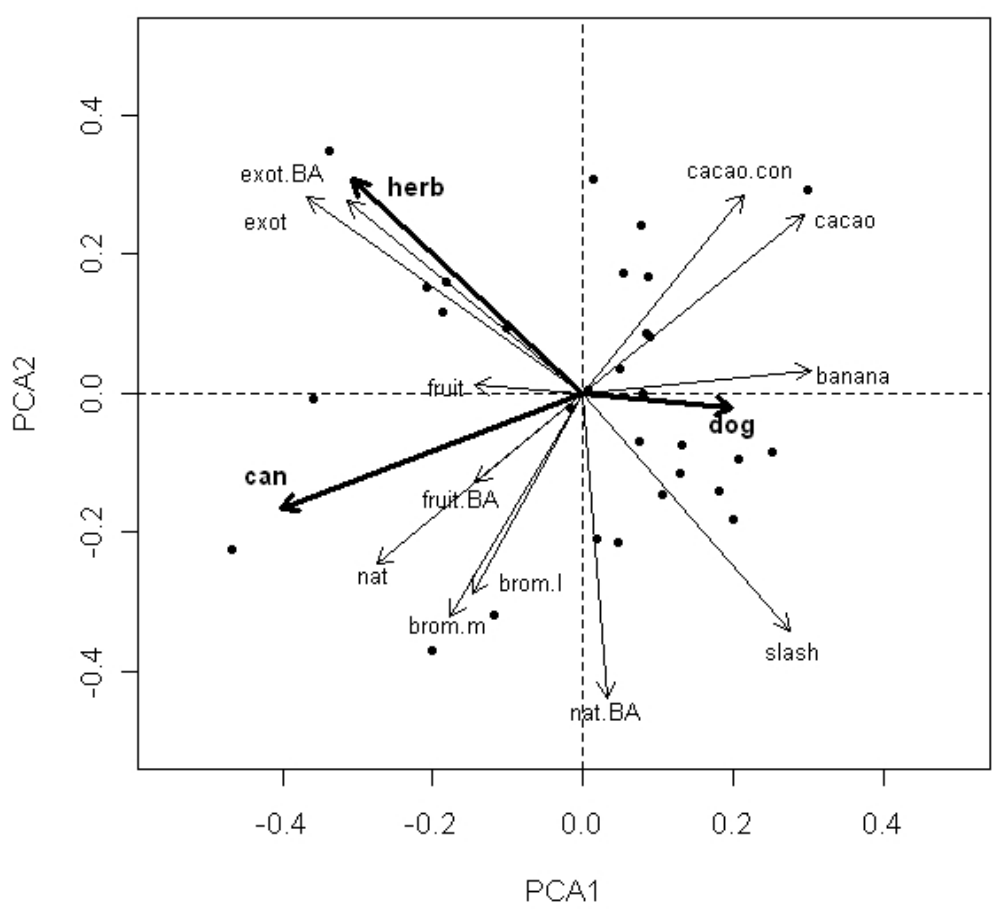

Figure S1: Ordination of sampling sites (dots) in a PCA bi-plot according to vegetation measurements and domestic dog capture rate. Indication of the variables included in model selection analysis (darker arrows): can = canopy connectivity index, herb $=$ average herbaceous vegetation height, and $\operatorname{dog}=$ domestic dog capture rate. Other vegetation measurements are: nat, fruit and exot= number of native, exotic fleshy fruit and exotic nonfleshy fruit trees; nat. $\mathrm{AB}$, fruit. $\mathrm{AB}$ and exot. $\mathrm{AB}=$ sum of basal area from native, exotic fleshy fruit and exotic non-fleshy fruit trees; brom.m and brom.l = number of medium and large bromeliads on tree crows; cacao $=$ number of cacao shrubs; cacao.con $=$ cacao connectivity index; banana $=$ number of banana stems; slash $=$ frequency of herbaceous vegetation clearance. 


\section{DISCUSSÃO GERAL}

A contribuição de agroflorestas com estrato arbóreo diversificado para a mitigação dos efeitos da perda e fragmentação florestal tem sido apontada em estudos científicos há mais de duas décadas, com avanços recentes no que diz respeito às possibilidades de síntese das similaridades e diferenças nas respostas entre grupos biológicos e à contextualização da paisagem. Perfecto et al. (1996), Moguel \& Toledo (1999), Rice \& Greenberg (2000) discutem a importância das agroflorestas de cacau e café para a conservação de biodiversidade a partir do resultado de estudos, publicados até o final da década de 90, que contrastam as agroflorestas com remanescentes de vegetação nativa e agroecossistemas de manejo mais intensivo. Estas publicações, que sintetizam grande parte do conhecimento sobre a biodiversidade em agroflorestas existente na época, demonstram que poucos estudos haviam abordado a importância da quantidade ou configuração espacial dos ambientes, com grande parte das informações concentradas em poucos grupos biológicos: artrópodes, um grupo de interesse econômico com muitas espécies que atuam como pragas e polinizadores ou são predadores desses, e aves, sobretudo espécies migratórias. As pesquisas realizadas no sul da Bahia e revisadas no capítulo 1 foram, com poucas exceções, publicadas num período mais recente. Além de termos encontrado estudos sobre diversos táxons e sobre espécies ameaçadas de extinção, esta revisão se beneficiou de um conjunto de estudos com delineamento amostral padronizado entre grupos biológicos e da comparação da diversidade de espécies entre duas paisagens com diferentes proporções de cobertura florestal remanescente e agroflorestas. Isto nos possibilitou identificar fatores importantes para manter biodiversidade e recomendar ações de manejo em pelo menos duas escalas distintas: da plantação e da paisagem.

Os capítulos 2 e 3 ampliam o conhecimento sobre a distribuição de mamíferos de maior porte em uma paisagem da região cacaueira do sul da Bahia e para paisagens agroflorestais de maneira geral. As informações sobre mamíferos de maior porte nas cabrucas do sul da Bahia disponíveis até 2008 e revisadas no primeiro capítulo são provenientes principalmente de estudos realizados com espécies individuais, e muitos estudos não publicados ou publicados em eventos científicos nacionais, portanto de divulgação limitada. Nesses estudos, as inferências a respeito das respostas dos mamíferos ao tipo de ambiente, intensificação do manejo e redução da cobertura florestal, embora possíveis, são baseadas em evidências fracas devido a conjuntos de dados limitados ou delineamentos 
inadequados para responder tais questões. Para outras regiões Neotropicais, já existiam na época estudos publicados avaliando assembléias de mamíferos de maior porte nas agroflorestas (Estrada et al. 1994, Harvey et al. 2006), nos quais a inferência sobre a influência do manejo advinha da comparação categórica entre agroflorestas e plantações perenes de manejo intensivo e inferências sobre a importância da cobertura florestal advinham da comparação entre agroflorestas e remanescentes de vegetação nativa. Um único estudo comparando um gradiente de intensificação de plantações de café (Gallina et al. 1996) se baseou no contraste de apenas quatro sítios amostrais. A comparação entre cabrucas e florestas, realizada no capítulo 2, teve como diferencial em relação a esses trabalhos anteriores um delineamento pareado com o qual minimizamos a influência do contexto da paisagem no entorno dos sítios sobre os padrões observados. No capítulo 3 , além de considerarmos o manejo das agroflorestas ao longo de um gradiente com 30 unidades amostrais, comparamos a importância relativa da intensificação do manejo e da cobertura florestal no entorno dos sítios.

Assim como avanços importantes aconteceram nos estudos realizados no sul da Bahia, o conhecimento sobre biodiversidade em sistemas agroflorestais tem sido ampliado em outras regiões onde esses sistemas ocupam grandes extensões da matriz, com comparações multi-taxa cada vez mais freqüentes (ex.: Perfecto et al. 2003, Steffan-Dewenter et al. 2007, Clough et al. 2011, Waltert et al. 2011) e estudos contrastando a importância do manejo versus a distribuição de cobertura vegetal remanescente (ex: Bali et al. 2007, Clough et al. 2009, Clough et al. 2010). Além disso, estudos avaliando grupos com diferentes requerimentos de habitat têm apontado as limitações das agroflorestas em manter espécies estritamente florestais, tanto na Bahia (Pardini et al. 2009) quanto fora dessa região (Waltert et al. 2011), e a avaliação de grupos funcionais tem permitido inferências sobre a importância da biodiversidade das agroflorestas na manutenção de serviços ecossistêmicos (Klein et al. 2003, Clough et al. 2009).

\section{Principais resultados e implicações para a conservação de biodiversidade em paisagens agroflorestais}

De maneira similar às revisões de trabalhos publicados até o final da década de 90 , os estudos compilados no capítulo 1 demonstram que as agroflorestas com sombreamento diversificado são utilizadas por uma parcela substancial da fauna e flora nativas, mas que 
isso depende de características da plantação que são, por sua vez, afetadas pelo manejo. Ao rever elementos chave que influenciam a diversidade das comunidades e o uso das cabrucas por espécies ameaçadas de extinção, tecemos recomendações para o manejo das plantações que vão desde a indicação de espécies arbóreas para serem mantidas através do planejamento de remoção, poda e regeneração, até a indicação de estruturas simples que aumentam a complexidade estrutural (ex: troncos mortos, cupinzeiros e epífitas) e a coibição da caça.

No que se refere ao manejo na escala da paisagem, sugerimos, em paisagens muito desmatadas, o acréscimo de cobertura vegetal atendendo à legislação ambiental vigente e um manejo das agroflorestas “amigável” à conservação. Essas ações devem garantir grande quantidade de habitat para as espécies menos vulneráveis e a manutenção de metapopulações viáveis de espécies com distribuição limitada nas cabrucas. Já em paisagens com porcentagem de cobertura florestal elevada (tomando uma paisagem com $50 \%$ de cobertura florestal como referência), os estudos revistos indicam que as agroflorestas ampliam a conectividade e garantem uma distribuição bastante homogênea das espécies. Nessas paisagens, remanescentes florestais pequenos mantêm assembléias de espécies similares aos trechos de vegetação contínua e esta parece ser uma situação favorável para a manutenção de populações da maior parte das espécies nativas, com exceção daquelas diretamente exploradas pelo homem como mamíferos (capítulos 2 e 3) e árvores (Pardini et al. 2009). Partindo das semelhanças de composição e estrutura registradas entre as cabrucas e os remanescentes florestais, sugerimos ainda o uso das agroflorestas como buffers no entorno de remanescentes florestais para reduzir efeitos de borda.

Nos capítulos 2 e 3 mostramos que, embora o número de espécies registradas nas cabrucas e remanescentes florestais de um mosaico agroflorestal com grande porcentagem de vegetação nativa seja elevado, a representatividade de espécies caçadas ou mortas por retaliação é baixa quando comparada a estudos que utilizaram o mesmo método de amostragem em florestas contínuas (ex: Silveira et al. 2003, Srbek-Araujo \& Chiarello 2005, Tobler et al. 2008). Também mostramos que a maior incidência de cães domésticos, considerada uma consequência indireta da intensificação do manejo, reduz o uso das cabrucas por mamíferos e que tanto a conversão de florestas em cabrucas quanto a intensificação do manejo das agrofloretas afetam negativamente espécies arborícolas e positivamente espécies generalistas. Ao comparar as causas proximais (intensificação do 
manejo versus cobertura florestal) responsáveis pela redução do uso das cabrucas por mamíferos de maior porte, encontramos que as variáveis relacionadas ao manejo têm efeitos negativos mais importantes sobre este grupo. Argumentamos, no entanto, que este resultado deve ser entendido dentro do contexto da área de estudo - uma paisagem bastante florestada e com uma assembléia de mamíferos empobrecida em conseqüência da sobrecaça - e que, a exemplo de outros estudos (ex: Tscharntke et al. 2005, Pardini et al. 2010, Batary et al. 2011), respostas mais pronunciadas à intensificação do manejo e/ou à redução da cobertura florestal numa escala pequena devem ocorrer em paisagens mais desmatadas, alterando a importância relativa entre esses fatores.

Diante desses resultados, inferimos que o controle de populações de cães domésticos e de atividades de caça são as ações de manejo que devem produzir grande benefício para a manutenção de mamíferos de maior porte em paisagens agroflorestais e podem ser implementadas sem reduzir a produtividade local das plantações. A manutenção de sombreamento deve ser adotada com o objetivo de aumentar a disponibilidade de habitat e conectividade da paisagem para espécies arborícolas, mas deve ser avaliada também em função da produtividade. Na paisagem de estudo, a elevada porcentagem de cobertura florestal é importante e deve ser mantida, porém a distribuição espacial dos remanescentes exerce pouca influência nas populações de mamíferos de maior porte.

\section{Desafios futuros para aprimorar o uso das agroflorestas como ferramenta para conservação}

Após reunir informações sobre a biodiversidade nas cabrucas do sul da Bahia no capítulo 1, identificamos questões que, ao serem investigadas e esclarecidas por estudos futuros, poderão auxiliar no refinamento das estratégias para conciliar a conservação e a produção agrícola nas paisagens agroflorestais. Entre os assuntos identificados como prioritários e carentes de conhecimento estão: (1) densidades de sombreamento "ótimas" que maximizem ganhos ambientais e econômicos, (2) limiares de cobertura florestal e fragmentação relacionados à perda acentuada de espécies em paisagens agroflorestais e (3) identificação de relações entre recursos chave (ex. disponibilidade de alimento e abrigo, estrutura da vegetação, condições microclimáticas) e a diversidade e riqueza de espécies nas cabrucas, principalmente espécies dependentes de floresta. 
Relações entre produtividade e diversidade de espécies têm sido avaliadas em plantações de cacau da Indonésia. Clough et al. (2011) encontraram uma riqueza constante de pequenos vertebrados, invertebrados, fungos e árvores ao longo de um gradiente de produtividade entre plantações, mesmo considerando apenas espécies florestais no caso das aves. Para esses autores, níveis moderados de sombreamento (30-40\%) e tratos manuais da lavoura podem garantir produtividade sem reduzir o valor de conservação das agroflorestas, ao menos em regiões tropicais ocupadas por pequenas propriedades. A partir disso, sugerem que estratégias wildlife-friendly podem resultar nos maiores ganhos ambientais e econômicos nessas paisagens. Em um trabalho anterior, Steffan-Dewenter et al. (2007) também sugerem um máximo benefício ambiental e econômico em níveis intermediários de sombreamento (35-50\%) ao contrastar o manejo local com a riqueza de espécies (invertebrados e plantas) e estimativas de serviços ecossistêmicos. Porém, para esses autores esta estratégia é uma opção intermediária entre a produção extensiva (wildlife-friendly) em larga escala e a intensificação das plantações aliada à proteção integral de áreas maiores de floresta. Os autores pontuam ainda alguns fatores importantes no que se refere ao balanço entre intensificação do manejo e manutenção de cobertura florestal nas estratégias para conciliar produtividade e conservação, com os quais chamam atenção para questões mais abrangentes que não podem ser respondidas em seu estudo. Primeiro, apontam a ausência de informação sobre efeitos adicionais aos do manejo que podem decorrer do isolamento das plantações em relação a áreas fonte, ou seja, que o nível de sombreamento "ótimo" encontrado por eles pode variar entre paisagens com diferentes porcentagens de cobertura florestal e em função da distribuição espacial dos remanescentes de vegetação. Em segundo lugar, indicam que poucos pequenos produtores rurais possuem capacidade de sustentar altos níveis de produtividade nas lavouras intensificadas devido ao alto custo de produção, portanto, que o componente sócio-econômico impõe limitações à intensificação. Finalmente, destacam a importância de se definir metas de conservação: serviços ecossistêmicos associados à biodiversidade ou táxons ameaçados altamente dependentes dos habitats naturais?

De fato, grande parte das publicações a respeito de estratégias para conciliar produção agrícola e conservação analisa apenas parte das questões envolvidas, e isso parece limitar as conclusões a respeito da contribuição da intensificação do uso da terra e manutenção de habitat nativo. Entre os estudos que apontam a intensificação agrícola associada a mais áreas com vegetação intacta como melhor alternativa, uma premissa comum é de que 
existe uma relação direta entre a extensão de cobertura de vegetação remanescente e conservação de biodiversidade (Balmford et al. 2005, Ewers et al. 2009, Phalan et al. 2011), ignorando a importância de processos ecológicos que dependem da matriz agrícola e de distúrbios que se propagam desta para os remanescentes de vegetação. Já os estudos que apontam os sistemas extensivos como opção mais favorável raramente consideram uma possível expansão das plantações, decorrente do aumento da demanda, e seu avanço sobre áreas de vegetação nativa (Harvey et al. 2008, Perfecto \& Vandermeer 2008).

No que se refere ao conhecimento biológico, esta discussão é limitada em parte porque os estudos nos quais se baseiam avaliaram a distribuição das espécies ou assembléias tendo sítios ou manchas de ambientes (ex. fragmentos, plantações) como unidades amostrais. Segundo Bennett et al. (2006), a compreensão das propriedades de mosaicos de ambientes devem ter como unidades de amostragem mosaicos inteiros, com seus diversos usos da terra representados. Entretanto, vale ressaltar que a escala de resposta das espécies varia. Enquanto alguns quilômetros quadrados podem ser considerados unidades amostrais válidas para representar mosaicos de uso da terra que influenciam na dinâmica de populações de algumas espécies (Bennett et al. 2006), nosso estudo indica que mamíferos de maior porte devem responder a características da paisagem em escalas muito mais amplas. O papel das agroflorestas para conciliar conservação e produção agrícola será aprimorado também com o desenvolvimento de mais estudos que quantifiquem, além da diversidade de espécies, os processos ecológicos mantidos nas plantações, bem como a influência desses sistemas na atenuação de efeitos de borda, que constitui um fator importante para a deterioração do habitat florestal em paisagens fragmentadas (Oliveira et al. 2008, Faria et al. 2009).

Como mencionado nas discussões dos capítulos, o conhecimento atual permite a inferência de medidas para garantir e/ou aumentar a diversidade biológica em paisagens modificadas pelo homem e pode ser traduzido em ações de manejo. No que diz respeito ao embasamento biológico, a avaliação e adaptação das práticas sugeridas com o avanço do conhecimento são pontos importantes para garantir a sustentabilidade dessas paisagens. Outros desafios tão ou mais importantes para viabilizar e manter no longo prazo a biodiversidade e serviços ambientais associados e a produção agrícola são a incorporação de fatores sócio-econômicos e o suporte de políticas públicas que, por sua vez, dependem do envolvimento de profissionais de áreas distintas e da conciliação de interesses de diferentes segmentos da sociedade. 


\section{Referências Bibliográficas}

Bali, A., A. Kumar, and J. Krishnaswamy. 2007. The mammalian communities in coffee plantations around a protected area in the Western Ghats, India. Biol. Conserv. 139: 93-102.

Balmford, A., R. E. Green, and J. P. W. Scharlemann. 2005. Sparing land for nature: Exploring the potential impact of changes in agricultural yield on the area needed for crop production. Global Change Biology 11: 1594-1605.

Batary, P., B. Andras, D. Kleijn, and T. TscharntKe. 2011. Landscape-moderated biodiversity effects of agri-environmental management: A meta-analysis. Proceedings of the Royal Society 278: 1894-1902.

Bennett, A. F., J. Q. Radford, and A. Haslem. 2006. Properties of land mosaics: Implications for nature conservation in agricultural environments. Biol. Conserv. 133: 250-264.

Clough, Y., S. Abrahamczyk, M. O. Adams, A. Anshary, N. Ariyanti, L. Betz, D. Buchori, D. Cicuzza, K. Darras, D. D. Putra, B. Fiala, S. R. Gradstein, M. Kessler, A. M. Klein, R. Pitopang, B. Sahari, C. Scherber, C. H. Schulze, Shahabuddin, S. G. Sporn, K. Stenchly, S. S. Tuitrosoedirdjo, T. C. Wanger, M. Weist, A. Wielgoss, and T. TscharntKe. 2010. Biodiversity patterns and trophic interactions in human-dominated tropical landscapes in Sulawesi (Indonesia): Plants, arthropods and vertebrates. In: T. Tscharntke, C. Leuschner, E. Veldkamp, H. Faust, E. Guhardja and A. Bidin (Eds.). Tropical Rainforests and Agroforests Under Global Changes: Eological and Socio-Economic Valuations. Springer, New York, NY, pp. $15-71$.

Clough, Y., J. Barkmann, J. Juhrbandt, M. Kessler, T. C. Wanger, A. Anshary, D. Buchori, D. Cicuzza, K. Darras, D. D. Putra, S. Erasmi, R. Pitopang, C. Schmidt, C. H. Schulze, D. Seidel, I. Steffan-Dewenter, K. Stenchly, S. Vidal, M. Weist, A. C. Wielgoss, and T. TscharntKe. 2011. Combining high biodiversity with high yields in tropical agroforests. Proc. Natl. Acad. Sci. USA 108: 8311-8316.

Clough, Y., D. D. Putra, R. Pitopang, and T. TscharntKe. 2009. Local and landscape factors determine functional bird diversity in Indonesian cacao agroforestry. Biol. Conserv. 142: 1032-1041. 
Estrada, A., R. Coatesestrada, and D. Meritt. 1994. Non-flying mammals and landscape changes in the tropical rain-forest region of Los-Tuxtlas, Mexico. Ecography 17: 229-241.

Ewers, R. M., J. P. W. Scharlemann, A. Balmford, and R. E. Green. 2009. Do increases in agricultural yield spare land for nature? Global Change Biology 15: 17161726.

Faria, D., E. Mariano-Neto, A. M. Z. Martini, J. V. Ortiz, R. Montingelli, S. Rosso, M. L. B. Paciencia, and J. Baumgarten. 2009. Forest structure in a mosaic of rainforest sites: The effect of fragmentation and recovery after clear cut. For. Ecol. Manage. 257: 2226-2234.

Gallina, S., S. Mandujano, and A. GonZalez-Romero. 1996. Conservation of mammalian biodiversity in coffee plantaitons of Central Veracruz, Mexico. Agroforestry Systems 33: 13-27.

Harvey, C. A., J. Gonzalez, and E. Somarriba. 2006. Dung beetle and terrestrial mammal diversity in forests, indigenous agroforestry systems and plantain monocultures in Talamanca, Costa Rica. Biodiversity Conserv. 15: 555-585.

Harvey, C. A., O. Komar, R. Chazdon, B. G. Ferguson, B. Finegan, D. M. Griffith, M. Martínez-Ramos, H. Morales, R. Nigh, L. Soto-Pinto, M. V. Breugel, and M. WISHNIE. 2008. Integrating agricultural landscapes with biodiversity conservation in the Mesoamerican hotspot. Conserv. Biol. 22: 8-15.

Klein, A. M., I. Steffan-Dewenter, and T. TscharntKe. 2003. Pollination of Coffea canephora in relation to local and regional agroforestry management. J. Appl. Ecol. 40: 837-845.

Moguel, P., and V. M. Toledo. 1999. Biodiversity conservation in traditional coffee systems of Mexico. Conserv. Biol. 13: 11-21.

Oliveira, M. A., A. M. M. Santos, and M. TABarelli. 2008. Profound impoverishment of the large-tree stand in a hyper-fragmented landscape of the Atlantic forest. For. Ecol. Manage. 256: 1910-1917.

Pardini, R., A. D. Bueno, T. A. Gardner, P. I. Prado, and J. P. Metzger. 2010. Beyond the fragmentation threshold hypothesis: Regime shifts in biodiversity across fragmented landscapes. Plos One 5: e13666. 
Pardini, R., D. Faria, G. M. Accacio, R. R. Laps, E. Mariano-Neto, M. L. B. Paciencia, M. Dixo, and J. Baumgarten. 2009. The challenge of maintaining Atlantic forest biodiversity: A multi-taxa conservation assessment of specialist and generalist species in an agro-forestry mosaic in southern Bahia. Biol. Conserv. 142: 1178-1190.

Perfecto, I., A. Mas, T. Dietsch, and J. VAndermeer. 2003. Conservation of biodiversity in coffee agroecosystems: A tri-taxa comparison in southern Mexico. Biodiversity Conserv. 12: 1239-1252.

Perfecto, I., R. A. Rice, R. Greenberg, and M. E. VanderVoort. 1996. Shade coffee: A disappearing refuge for biodiversity. Bioscience 46: 598-608.

Perfecto, I., and J. VANDERMEer. 2008. Biodiversity conservation in tropical agroecosystems - A new conservation paradigm. Ann. N.Y. Acad. Sci. 1134: 173-200.

Phalan, B., M. Onial, A. Balmford, and R. E. Green. 2011. Reconciliating food production and biodiversity conservation: Land sharing and land sparing compared. Science 333: 1289-1291.

Rice, R. A., and R. Greenberg. 2000. Cacao cultivation and the conservation of biological diversity. Ambio 29: 167-173.

Silveira, L., A. T. A. Jacomo, and J. A. F. Diniz. 2003. Camera trap, line transect census and track surveys: A comparative evaluation. Biol. Conserv. 114: 351-355.

SrbeK-Araujo, A. C., and A. G. Chiarello. 2005. Is camera-trapping an efficient method for surveying mammals in neotropical forests? A case study in south-eastern Brazil. J. Trop. Ecol. 21: 121-125.

Steffan-Dewenter, I., M. Kessler, J. Barkmann, M. M. Bos, D. Buchori, S. Erasmi, H. Faust, G. Gerold, K. Glenk, S. R. Gradstein, E. Guhardja, M. Harteveld, D. Hertel, P. Hohn, M. Kappas, S. Kohler, C. Leuschner, M. Maertens, R. Marggraf, S. Migge-Kleian, J. Mogea, R. Pitopang, M. Schaefer, S. Schwarze, S. G. Sporn, A. Steingrebe, S. S. Tuitrosoedirdjo, S. Tutrrosoemito, A. Twele, R. Weber, L. Woltmann, M. Zeller, and T. TscharntKe. 2007. Tradeoffs between income, biodiversity, and ecosystem functioning during tropical rainforest conversion and agroforestry intensification. Proc. Natl. Acad. Sci. USA 104: 4973-4978. 
Tobler, M. W., S. E. Carrillo-Percastegui, R. L. Pitman, R. Mares, and G. Powell. 2008. An evaluation of camera traps for inventorying large- and medium-sized terrestrial rainforest mammals. Animal Conservation 11: 169-178.

Tscharntke, T., A. M. Klein, A. Kruess, I. Steffan-Dewenter, and C. Thies. 2005. Landscape perspectives on agricultural intensification and biodiversity - Ecosystem service management. Ecol. Lett. 8: 857-874.

Waltert, M., K. S. Bobo, S. Kaupa, M. L. Montoya, M. S. Nsanyi, and H. Fermon. 2011. Assessing conservation values: Biodiversity and endemicity in tropical land use systems. Plos One 6: e16238. 